\title{
Earth science collections of the Centre Grégoire Fournier (Maredsous) with comments on Middle Devonian-Carboniferous brachiopods and trilobites from southern Belgium
}

\author{
BERNARD MOTTEQUIN
}

\author{
D.O. Terre et Histoire de la Vie, Institut royal des Sciences naturelles de Belgique, rue Vautier 29, B 1000 Brussels, Belgium, \\ bmottequin@naturalsciences.be.
}

\begin{abstract}
Although the Centre Grégoire Fournier of the Maredsous Abbey is especially famous for the fossils and minerals from the Carboniferous (Viséan) 'black marble' of Denée, a marine conservation-Lagerstätte, its palaeontological collections likewise include some types and illustrated specimens of invertebrates (cystoids, goniatites, ostracods, trilobites) and fishes from the Ordovician, Devonian and Carboniferous of Belgium. These specimens are discussed and/or illustrated as is the case of the fragments of two Belgian meteorites (Lesves and Tourinnes-la-Grosse chondrites) that are part of the CGF mineralogical and petrological collections. Moreover, the type material of 30 species and subspecies of Upper Devonian-Pennsylvanian linguliformean and rhynchonelliformean brachiopods (described by de Koninck (1847), J. Fraipont (1888a), Ch. Fraipont (1908), Demanet (1923, 1934), Demanet (in Demanet \& Van Straelen, 1938), and Grimm (1998)) and that of two Middle-Upper Devonian species of trilobites (Stainier, 1887; Richter \& Richter, 1933), almost all from the Namur-Dinant Basin (southern Belgium), are re-investigated and/or fully figured for the first time in order to facilitate future taxonomic revision. The obscure Tournaisian genus Anomianella de Ryckholt (1851) is rejected from the bivalves and transferred to the brachiopods (Craniida). It is probably related to Petrocrania Raymond, 1911. The lectotype of Orthis latissima $\mathrm{M}^{`} \mathrm{Coy}, 1844$ and that of Producta corrugata $\mathrm{M}^{\circ} \mathrm{C}$ Coy, 1844, both from the Viséan of Ireland, are photographically illustrated (for the first time for the former). The lectotype of Productus murchisonianus de Koninck, 1847 from the Upper Palaeozoic of Tasmania (Australia) is also designated.
\end{abstract}

KEYWORDS: Ordovician, Devonian, Carbonifer ous, palaeontology, mineralogy, meteorites, Belgium.

\section{Introduction}

The Centre Grégoire Fournier (CGF) is part of the Maredsous Abbey (Denée, southern Belgium) and is home to the most important collection of invertebrates (e.g., brachiopods, echinoids, graptolites) and vertebrates (fishes) from the Viséan (Moliniacian) 'black marble' of Denée, which ranks among the few fossil conservation deposits of the Belgian Carboniferous (see references in Mottequin, 2008a and Mottequin et al., 2015). Although the other palaeontological collections gathered by Dom Grégoire Fournier (1863-1931) cannot be compared with those of the 'black marble' of Denée, they include some types and illustrated specimens, notably of goniatites (Delépine, 1940) and fishes (Leriche, 1908), but also worthwhile material generally coming from Ordovician-Carboniferous sections located around Maredsous

The Centre Grégoire Fournier was originally the museum of natural sciences of the abbatial school of the Maredsous Abbey (Genard, 2018, 2019). Besides the mineralogical and palaeontological collections, this local museum comprises archaeological, botanical, petrological and zoological ones (Henrard, 1951; Parent, 1977, 1979).

The three first objectives of the paper are related to the Centre Grégoire Fournier. This contribution aims at (1) providing brief information on its mineralogical and petrological (meteorites) collections, (2) documenting the types and illustrated specimens included in its palaeontological collections (to the exception of those from the 'black marble' of Denée, see above), and (3) highlighting the other valuable collections/ specimens in order to promote their inclusion in future researches. The fourth objective is to discuss and to illustrate thoroughly the type specimens of several brachiopod (J. Fraipont, 1888a; Ch. Fraipont, 1908; Demanet, 1923, 1934; Demanet in Demanet \& Van Straelen, 1938; Grimm, 1998) and trilobite (Stainier, 1887; Richter \& Richter, 1933) species and subspecies from the Middle Devonian-Carboniferous of Belgium.

\section{Stratigraphy}

The reader is referred to Verniers et al. (2002), Bultynck \& Dejonghe (2002), Poty et al. (2002), Delmer et al. (2002), and Robaszynski et al. (2002) (and references herein) for the description of the Ordovician, Devonian, Carboniferous, and Cretaceous lithostratigraphic units of southern Belgium (Fig. 1) mentioned in the text, respectively.

Most of the species discussed here are from the TournaisianViséan (Carboniferous; Fig. 2) carbonate rocks that extensively crop out in southern Belgium on both sides of the major MidiEifel fault zone, notably in the Brabant Parautochthon, the Haine-Sambre-Meuse Overturned Thrust Sheets, and the Dinant Synclinorium (Hance et al., 1999; Belanger et al., 2012) (Fig. 1). These Variscan structural elements constituted the NamurDinant Basin that developed along the southeastern margin of Laurussia during Devonian and Mississippian times.

Correlations of the Tournaisian (Hastarian, Ivorian) and Viséan (Moliniacian, Livian, Warnantian) Belgian substages, which are used here, with other chronostratigraphic units were discussed notably by Poty et al. $(2006,2014)$.

\section{Material and methods}

The bulk of the fossils and meteorites illustrated here are housed at the Centre Grégoire Fournier (prefixed CGF) of the Maredsous Abbey (Denée) and at the Royal Belgian Institute of Natural Sciences (prefixed RBINS), Brussels. Additional investigated material is curated at the Université de Liège (palaeontological collections, prefixed ULg.PA), at the Université de Mons (Faculté Polytechnique, Service de Géologie Fondamentale et Appliquée, prefixed UMONS-GFA), and at the National Museum of Ireland (Geological Collection, Natural History Division; prefixed NMING), Dublin.

The species are described herein phylum by phylum and alphabetically classified by their specific name using their original generic assignment. In the legends of the figures, the original (old) names, which are sometimes corrected, are followed by current names given in square brackets. For each species, only the original references are provided, with few exceptions for which additional ones are cited.

Concerning the part devoted to the brachiopods (Section 6.2.), and to a lesser extent to the trilobites (Section 6.3.), most of the remarks expressed by Mottequin (2019) are still valid here and are discussed in Section 6.1.2. The present author aims at contributing to the assessment of the diversity in promoting and facilitating future taxonomic studies. For this reason, the type material of each species and variety is illustrated photographically and discussed, pending the study of further material. 


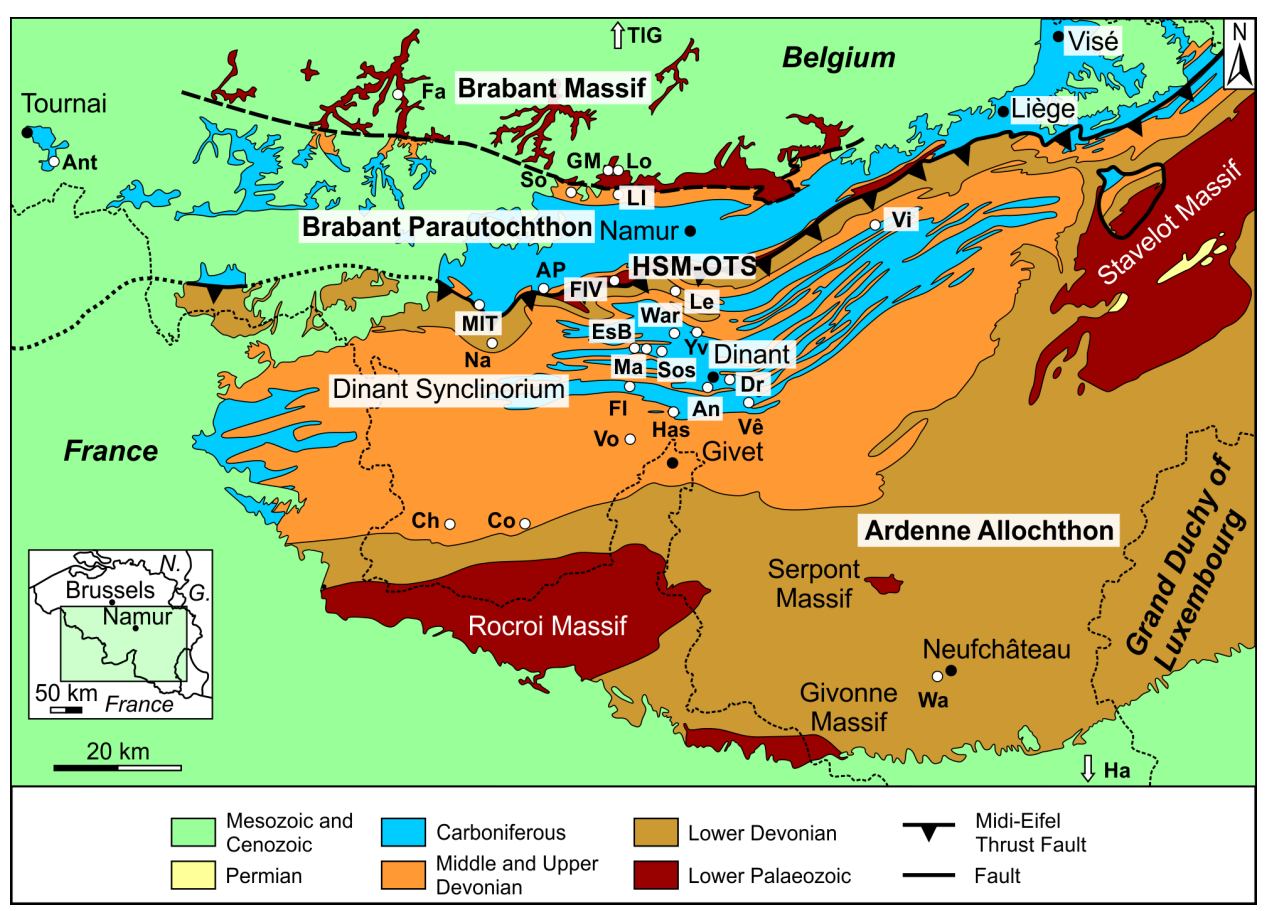

Figure 1. Location and schematic geological map of southern Belgium with indication of the localities cited in the text (modified from de Béthune, 1954). Abbreviations: An, Anseremme; Ant, Antoing; AP, Aiseau-Presles; Ch, Chimay; Co, Couvin; EsB, Ermeton-sur-Biert; Dr, Dréhance; Fa, Fauquez; Fl, Flavion; FIV, Fosses-la-Ville; GM, GrandManil; Ha, Halanzy; Has, Hastière; HSM-OTS, HaineSambre-Meuse Overturned Thrust Sheets (Belanger et al., 2012); Le, Lesves; LI, Les Isnes; Lo, Lonzée; Ma, Maredsous; MIT, Montignies-le-Tilleul; Na, Nalinnes; So, Sombreffe; Sos, Sosoye; TlG, Tourinnes-la-Grosse; Vê, Vêves; Vi, Vierset; Vo, Vodelée; Wa, Warmifontaine; War, Warnant; Yv, Yvoir (Poilvache).

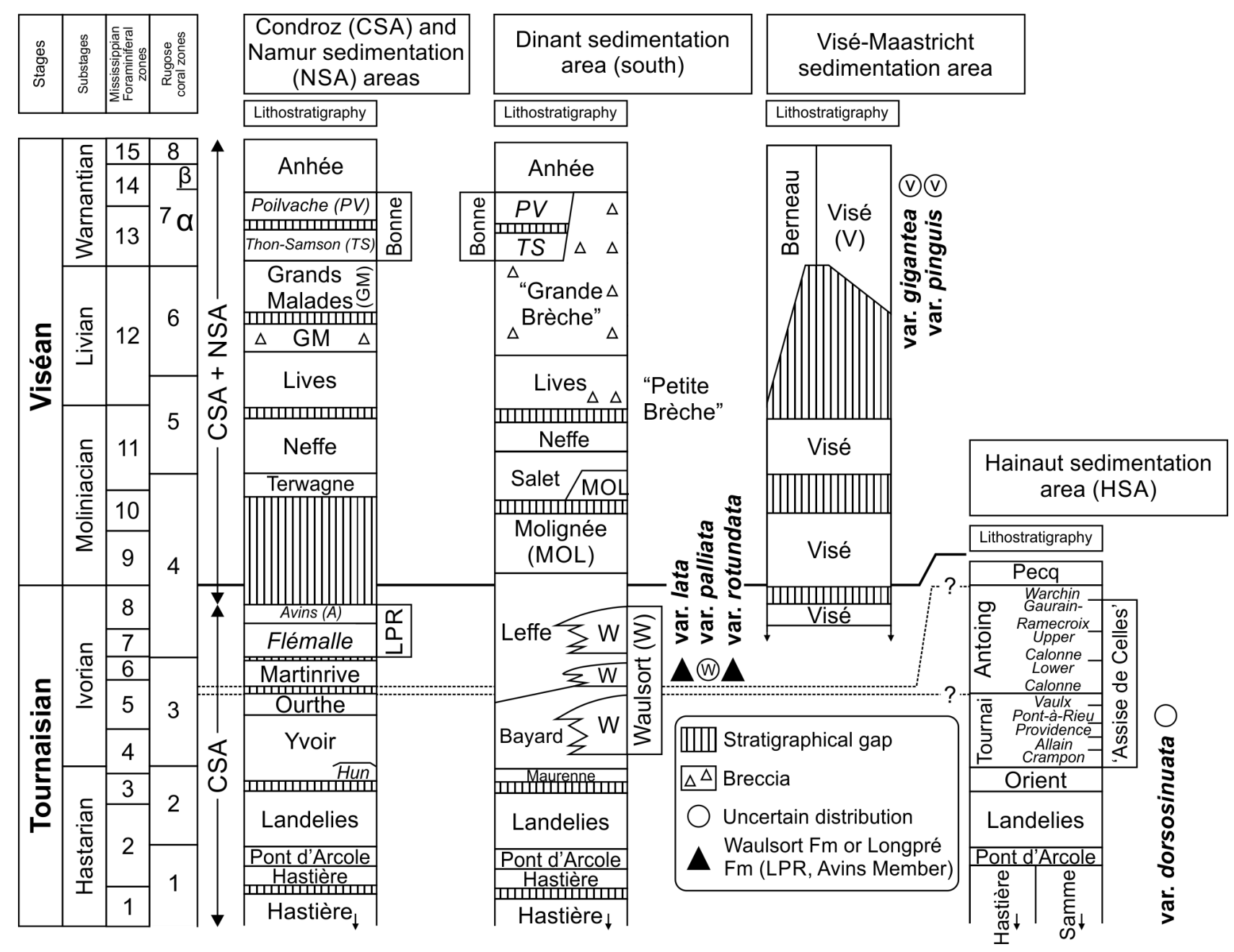

Figure 2. Stratigraphy, lithostratigraphy (incompletely represented here for the Hainaut and Visé-Maastricht sedimentation areas; formations and members are in roman and italic letters, respectively), and biostratigraphy of the essentially carbonate Tournaisian and Viséan succession of southern Belgium (adapted from Hance et al., 2006a, Poty et al., 2002, 2006, 2014, and Poty, 2016) with indication of the origin of the type material of the varieties of Schizophoria resupinata (Martin, 1809) erected by Demanet $(1923,1934)$ (see text). Note that the 'Grande Brèche' is an informal stratigraphic unit resulting from the dissolution of evaporitic levels in the Grands Malades Formation; other brecciated horizons, known as the 'Petite Brèche', locally occur within the lower part of the Lives Formation (Haut-le-Wastia Member). 
The smallest palaeontological specimens were photographed using a low-vacuum scanning electron microscope (ESEM FEI Quanta 200), but not coated with gold, whereas the larger ones were coated with ammonium chloride sublimate before being photographed.

\section{Mineralogical and meteorite collections of the CGF}

Although the CGF includes a large didactical mineralogy collection, only the specimens that were cited and/or described in the literature are mentioned here. The mineralogical species found in the Molignée Formation ('black marble' of Denée), namely calcite, fluorite, pyrite, quartz, sphalerite, and sulphur, were discussed by Buttgenbach (1898a, 1900, 1906a) and Fournier (in Fournier \& Kaisin, 1929). Aragonite (Fournier, 1899a), barytine (Buttgenbach, 1925), calcite (Buttgenbach, 1898b, 1906a, 1920, 1923, 1925), chalcedony (Fournier, 1899b), hopeite (Buttgenbach, 1906a), quartz (Fournier, 1897a, 1899c, 1904), and wavellite (Fournier, 1897b), which were discovered essentially in Dinantian rocks mainly cropping out in the neighbourhood of the Maredsous Abbey or in eastern Belgium, were the subjects of numerous short notes (see references above). Foreign collections include smithsonite crystals from Almaden (Spain) described by Buttgenbach (1906b).

A small fragment (CGF L945a; $48 \mathrm{~g}$ ) of the Lesves meteorite (Figs 1, 3A, 3C) (Fournier, 1896a; Renard, 1896), an olivine-enstatite chondrite (L6), is deposited at the CGF as well as a fragment (CGF L945b; $12 \mathrm{~g}$ ) of the Tourinnes-laGrosse one (Van Beneden, 1863) (Figs 1, 3B, 3D), an enstatite chondrite (L6). Besides these Belgian meteorites, it is worthwhile to cite fragments of those from Brenham (Kansas, USA; stony-iron, pallasite, CGF L880b; 17.9 g), Dundrum (Ireland; ordinary chondrite (H5), CGF L287; 2 g), Hedjaz (Saudi Arabia; ordinary chondrite (L3.7), CGF L282; 3.5 g), Mills (New Mexico, USA; ordinary chondrite (H6), CGF L378; 5 g), Odessa (Texas, USA; iron (IAB), coarse octahedrite, CGF L377; $7.5 \mathrm{~g}$ ), and Toluca (Mexico; iron (IAB), coarse octahedrite, CGF L1419; 39.5 g) (see Grady, 2000 for references). Some of these fragments were cited by Dewalque (1905). Further information on the rest of the petrological collections can be found in Henrard (1951).

\section{Palaeontological collections of the CGF}

\subsection{Type and/or illustrated specimens}

\subsubsection{Cephalopods}

\section{Beyrichoceras fournieri Delépine, 1940}

1940 Beyrichoceras fournieri Delépine, p. 19, 67-68, table 2, pl. 4, figs 1-2.

Type material. The only specimen available (CGF 2020.11.10/1) was considered by Delépine (1940, in caption of pl. 4, figs 1-2) as the type specimen and is thus the holotype by virtue of monotypy. However, this specimen has not been traced so far and is probably lost.

Type locality and horizon. According to Delépine (1940), the holotype was collected in the scree of a ravine on the northern flank of Poilvache (Yvoir, Fig. 1) in the Meuse valley (right side) and, on the basis of the lithological characters of the specimen, this author suggested that it probably originated from black limestones with black cherts, that is to say, probably from the Poilvache Member of the Bonne River Formation (Fig. 2) of early Warnantian age (Viséan).

Description. See Delépine (1940).

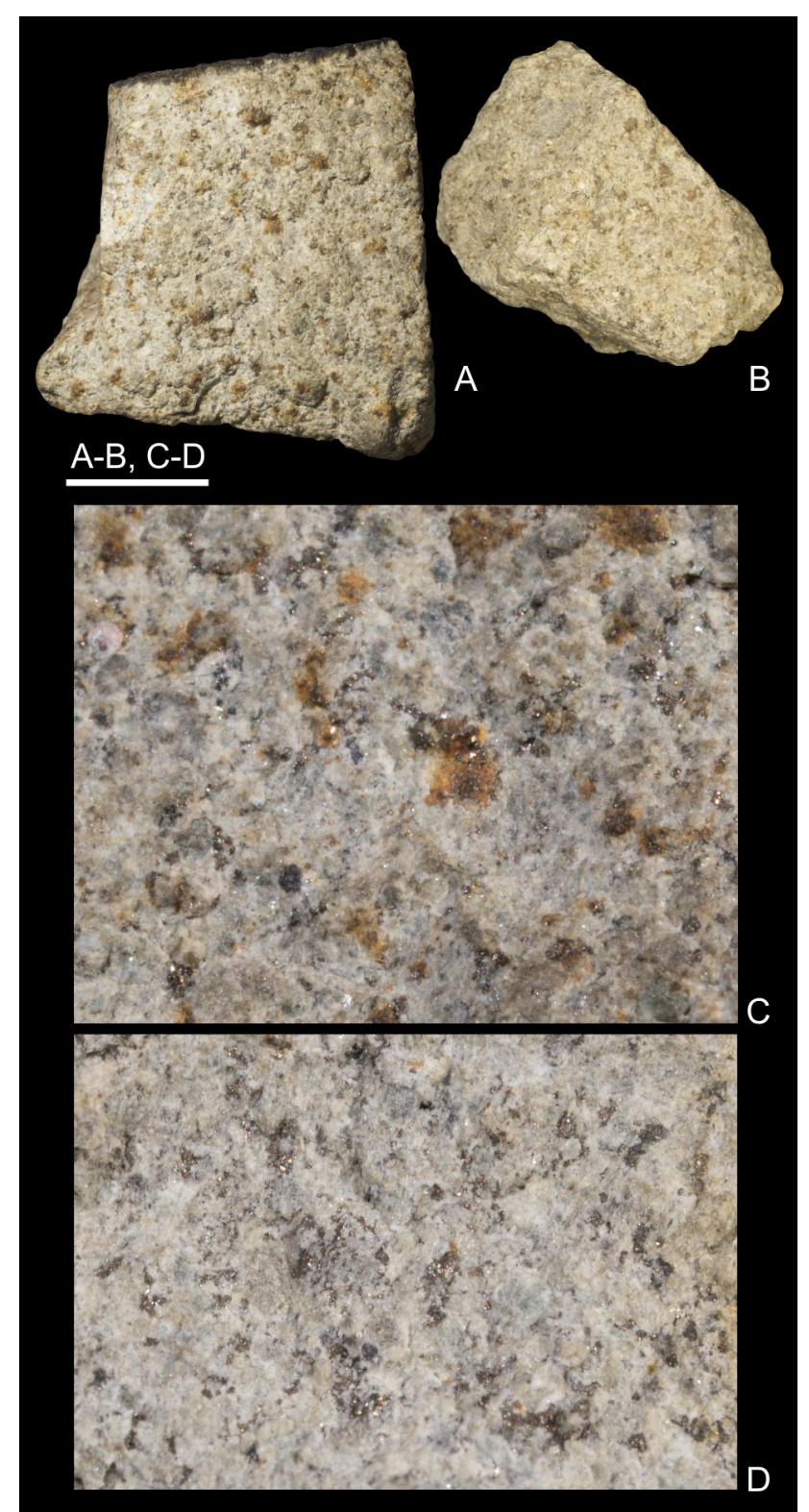

Figure 3. Belgian meteorites (chondrites) housed at the Centre Grégoire Fournier (Maredsous Abbey). A, C. CGF L945, olivineenstatite chondrite (L6), Lesves (April 13, 1896). B, D. CGF L945b, enstatite chondrite (L6), Tourinnes-la Grosse (December 7, 1863). Scale bar: $10 \mathrm{~mm}$ (A-B), $2.5 \mathrm{~mm}(\mathrm{C}-\mathrm{D})$.

Remarks. The species fournieri was assigned to the genus Beyrichoceratoides Bisat, 1924 (e.g., Bisat, 1952; Currie, 1954; Riley, 1996) whereas it was transferred to the genus Eoglyphioceras Brüning, 1923 by Dzik (1997) and Korn \& Ebbighausen (2008).

Current name. Eoglyphioceras fournieri (Delépine, 1940).

'Goniatites' (Pericyclus?) tuberculatus Delépine, 1940

(Fig. 4A-G)

1940 'Goniatites' (Pericyclus?) tuberculatus Delépine, p. $42-$ 43 , pl. 3 , fig. 7 .

Type material. The only specimen (CGF 2020.11.10/2) illustrated by Delépine (1940, pl. 3, fig. 7) is hereby designated as the lectotype (Fig. 4A-D) as this author failed to designate a holotype. A second specimen (CGF 2020.11.10/3) was 


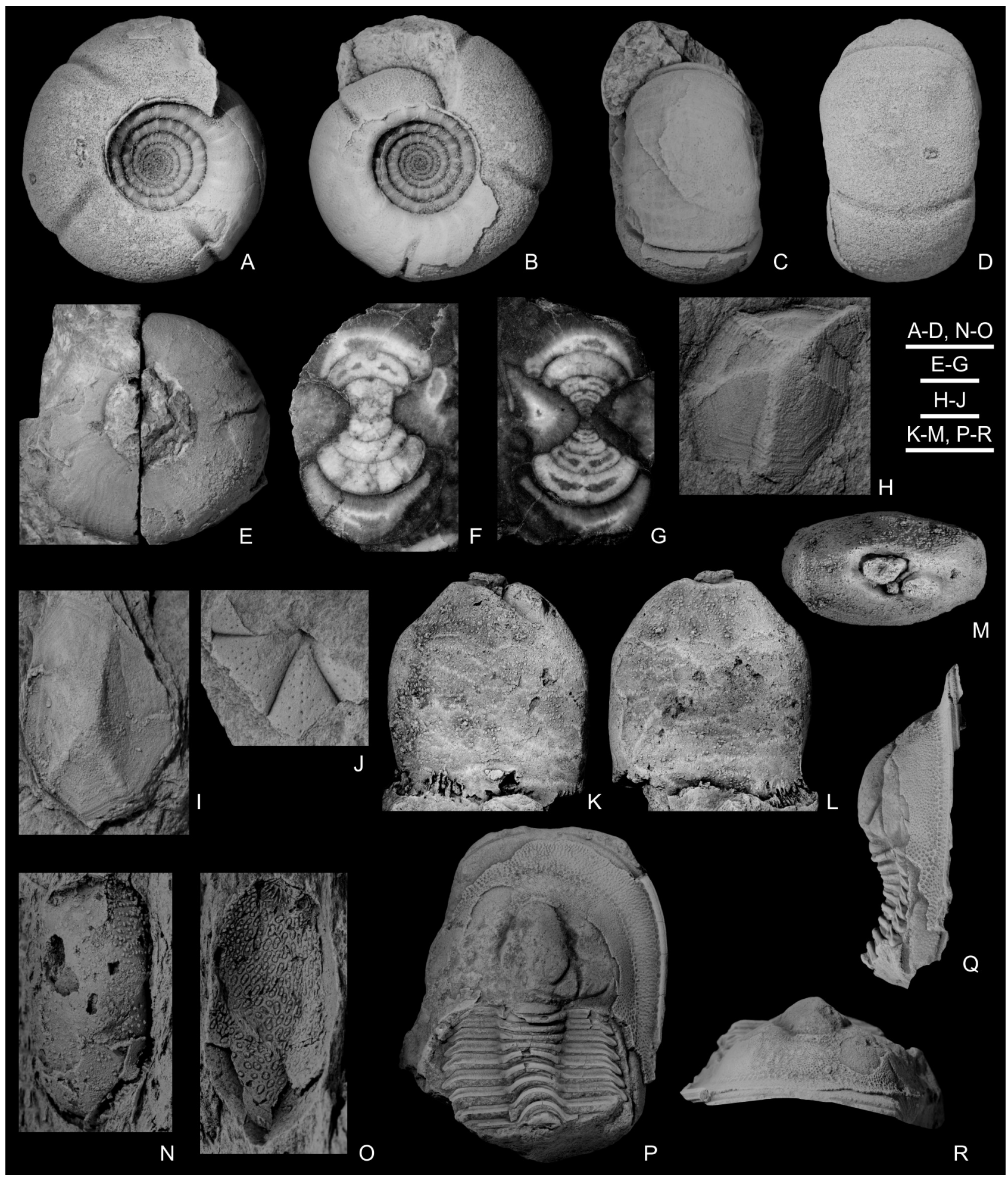

Figure 4. A-G. 'Goniatites' (Pericyclus?) tuberculatus Delépine, 1940 [Hammatocyclus? tuberculatus (Delépine, 1940)]; Flavion, Waulsort Formation (Tournaisian, Ivorian). A-D. CGF 2020.11.10/2 (lectotype), internal mould with shelly fragments. E-G. CGF 2020.11.10/3 (paralectotype), specimen sectioned transversally. H-J. Cheirocrinus cf. constrictus Bather, 1913 [Homocystes cf. constrictus (Bather, 1913)], internal moulds of isolated thecal plates; Fosses-la-Ville, Fosses Formation (Ashgill). H. CGF 2020.11.10/5. I. CGF 2020.11.10/6. J. CGF 2020.11.10/7. K-O. Haplosphaeronis proiciens Regnéll, 1951; Fauquez, Huet Formation (Katian). K-M. RBINS a7836 (holotype), internal mould of complete theca in left lateral, right lateral and oral views. N-O. CGF 2020.11.10/9 (paratype), internal and external (showing the fans of the ambulacral furrows) moulds of incomplete theca. P-R. Harpes macrocephalus Goldfuss, 1839, CGF 2020.11.10/13, incomplete specimen in dorsal, lateral and frontal views; Couvin (Trou Bodet), Jemelle Formation (Eifelian). Scale bars: 5 mm (A-D, N-O), 10 mm (E-G, K-M, P-R), 2 mm (H-J). 
mentioned but not figured by this author; therefore, it is a paralectotype and is illustrated here for the first time (Fig. 4E-G).

Type locality and horizon. Flavion (see Demanet, 1958), Waulsort Formation (Tournaisian, Ivorian) (Figs 1-2).

Description. See Delépine (1940).

Remarks. The species is listed in several publications, but the poor original illustrations and the restricted material available precluded a categoric generic assignment. It was tentatively assigned to Hammatocylcus Schindewolf, 1951 by Schindewolf (1951) and Ebbighausen et al. (2010). 1940).

Current name. Hammatocylcus? tuberculatus (Delépine,

\subsubsection{Echinoderms}

Remarks. Besides both cystoid species discussed below, Regnéll (1951, p. 37) reported an external mould (CGF 2020.11.10/4) of a stem fragment of Pelmatozoa (type A sensu Regnéll, 1951) from Grand-Manil (Fig. 1). It is from the Huet Formation of probably early Katian age according to Herbosch \& Verniers (2014). This specimen does not deserve to be figured here due to its poor state of preservation.

\section{Cheirocrinus cf. constrictus Bather, 1913}

(Fig. 4H-J)

1951 Cheirocrinus cf. constrictus Bather, 1913; Regnéll, p. 10-12, pl. 1, figs 1-8.

Material. On the eight specimens illustrated by Regnéll (1951, pl. 1, figs 1-8), three belong to the CGF collections and come from Fosses-la-Ville (Fig. 1): CGF 2020.11.10/5 (pl. 1, fig. 3; Fig. 4H), CGF 2020.11.10/6 (pl. 1, fig. 1; Fig. 4I), and CGF 2020.11.10/7 (pl. 1, fig. 7; Fig. 4J).

Description. See Regnéll (1951).

Remarks. These specimens from the Condroz Inlier were collected within the Ordovician (Ashgill) Fosses Formation. Bather's species was transferred to Homocystites Barrande, 1887 by Paul (1968) (see also Zamora et al., 2019).

Current name. Homocystites cf. constrictus (Bather, 1913).

Haplosphaeronis proiciens Regnéll, 1951

(Fig. 4K-O)

1951 Haplosphceronis [sic] proiciens Regnéll, p. 31-35, pl. 4, figs 1-7, pl. 5, figs 1-7, pl. 6, fig. 9.

Type material. See Regnéll (1951). Three paratypes from Fauquez (see below) were mentioned but not illustrated by this author: CGF 2020.11.10/8 (not traced), 2020.11.10/9 (Fig. 4NO), and 2020.11.10/10.

Type locality and horizon. Disused Huet quarry, north of Fauquez (Fig. 1) in the Sennette valley (Brabant Massif) (e.g., Vanmeirhaeghe et al., 2005; Verniers et al., 2005), Huet Formation (Ordovician, early Katian; see Herbosch \& Verniers' (2014) discussion on the age of this lithostratigraphic unit).

Description. See Regnéll (1951).

Remarks. New illustrations of the holotype (RBINS a 7836) (Regnéll, 1951, pl. 4, fig. 3) are provided here (Fig. 4K-M).

Current name. Haplosphaeronis proiciens Regnéll, 1951

\subsubsection{Ostracods}

Bairdia protracta Rome, 1971, non Eichwald, 1860
Type material. No holotype was designated by Rome (1971), who only illustrated a single specimen (RBINS b5719) by drawings; it is hereby designated as the lectotype (Rome, 1971, figs 29-30). The CGF collections include one unillustrated specimen (CGF 2020.11.10/11) from the type locality, which was identified by Rome (in coll.), and is accompanied by several drawings made by this author. There is no doubt that it is part of the type material and is thus considered as a paralectotype.

Type locality and horizon. Maredsous (see Conil, 1968) (Fig. 1), upper part of the Etrœungt Formation (latest Famennian, Strunian).

Description. See Rome (1971).

Remarks. Bairdia protracta Eichwald, 1860 (Silurian, a probable representative of the genus Rishona Sohn, 1960 according to Sohn, 1960) and Bairdia protracta Rome, 1971 are primary homonyms. The latter is a junior homonym and should be renamed. Attention is drawn to the fact that all the specimens illustrated by Rome (1971) are now curated at the RBINS (RBINS b5709-5736), except those identified as Beyrichiopsis annulata (figs 13-15), Bairdia aff. kinderhookensis (figs 31-32), Rectobairdia dilatata (figs 36-38), and Orthobairdia irregularis (figs 44-46) that are lost. Note that some Bairdia species (not protracta) described by Rome (1971) were revised by Lethiers (1975), who considered them as morphotypes of a single species.

Current name. Bairdia protracta Rome, 1971, non Eichwald, 1860.

\subsubsection{Trilobites}

Remarks. The CGF collections include one paratype (CGF 2020.11.10/12, unillustrated) of the upper Famennian species Omegops maretiolensis (Richter \& Richter, 1933) (see Section 6.3.).

Harpes macrocephalus Goldfuss, 1839

(Fig. 4P-R)

1897c Harpes macrocephalus Goldf.; Fournier, p. 52, unnumbered fig.

Material. CGF 2020.11.10/13 (Fig. 4P-R); Fournier (1897c) indicated that this incomplete specimen was collected from the Couvinian limestones of Petigny near Couvin, but the handwritten label, accompanying it, clearly indicates Couvin (Trou Bodet) as the locality (Fig. 1), which is most probably the right one, and it is thus from the Jemelle Formation (Eifelian). This fact is corroborated by Maillieux (1938, and unpublished RBINS archives) who indicated that this locality yielded Goldfuss' species (Couvin 3 in the RBINS archives).

Description. See Fournier (1897c).

Remarks. Although several authors reported the presence of trilobites in the Devonian of the Namur-Dinant Basin during the 19th century (see references in Taghon et al., 2012), few were described and/or illustrated. To our knowledge, Fournier's (1897c) specimen (CGF 2020.11.10/13) identified as Harpes macrocephalus Goldfuss, 1839 from the Eifelian of the Couvin area was the first to be illustrated photographically. This specimen was briefly discussed by Malaise (1897).

\subsubsection{Fishes}

Sandalodus morrisi Davis, 1883

(Fig. 5A-C)

1908 Sandalodus Morrisi Davis; Leriche, p. 283-285, pl. 8, fig. 6. 
Material. CGF 2020.11.10/14 (Fig. 5A-C), Yvoir (Fig. 1), Landelies Formation (Hastarian) (Fig. 2).

Description. See Leriche (1908).

Remarks. Leriche's (1908) report of this species is the only one in the Tournaisian of southern Belgium (Derycke et al., 1995).

Deltodus robustus (de Koninck, 1878)

(Fig. 5D-F)

1908 Deltodus robustus de Koninck; Leriche, p. 282-283, pl. 8 , fig. 5 .

Material. CGF 2020.11.10/15 (Fig. 5D-F), Ermeton-surBiert (Fig. 1), 'Assise d'Hastière (?)' according to Leriche (1908). After de Dorlodot's (1895) stratigraphic scheme followed by Leriche (1908), the 'Assise d'Hastière' included the Hastière, Pont d'Arcole, Landelies, and Maurenne formations (Fig. 2). The matrix enclosing the plate is a crinoidal limestone that indicates either the Hastière Formation or the Landelies Formation; both lithostratigraphic units are of Hastarian age.

Description. See Leriche (1908).

Remarks. According to de Koninck (1878), his species Sandalodus robustus, which was transferred to Deltodus Morris \& Roberts, 1862 by Leriche (1908), was erected on the basis of a single incomplete tooth plate that has thus to be considered as the holotype by monotypy. Until so far, this specimen has not been traced in the RBINS collections although Leriche (1908) noted, in a footnote, that he studied it at Brussels.

\subsection{Further comments on the CGF collections}

Except for the invertebrate and vertebrate collections from the Viséan 'black marble' of Denée (e.g., Mottequin et al., 2015), which rendered the CGF famous among the palaeontological community, the rest of CGF palaeontological collection consists of about 150 drawers including mostly Cambrian-Neogene invertebrates.

Palaeozoic and Cenozoic fossils come essentially from Belgium contrary to the Mesozoic ones which include many specimens from France and, to a lesser extent, from Germany and Switzerland. The scientific interest essentially lies in the Belgian specimens, especially those originating from the Devonian and Carboniferous outcrops more or less closely situated around the Maredsous Abbey (the Belgian fossiliferous localities are plotted in Fig. 1). Some collections deserve to be highlighted in this paragraph:

Ordovician invertebrates (e.g., brachiopods, trilobites, etc.) from the disused Lefèvre quarry (now inaccessible) at GrandManil (Huet Formation, early Katian) and from the Fosses-laVille area (Fosses Formation, Ashgill);

One enigmatic vertebrate from the Warmifontaine slate quarries (La Roche Formation; Pragian);

One exceptional longitudinal section of a large cephalopod (Manticoceras?) from a Frasnian mudmound (Vodelée?) (Fig. 5G);

One ophiuroid (Ophiaulax decheni (Dewalque, 1881); Fig. 5H) from the upper Famennian (Angertal-Schichten sensu Paul (1939), now included within the Velbert Formation, e.g., Amler \& Herbig, 2006) of the Ratingen area (Germany, Velbert Anticline), offered to the CGF in 1934 by H. Paul (Paul, 1939; Ubaghs, 1941; Schmidt, 1944);

One screw-shaped fossil of uncertain affinities named Spiraxis interstrialis by Stainier (1894) from Les Isnes quarries (Bois de la Rocq Formation; latest Famennian);

Invertebrates (e.g., brachiopods, molluscs) from the Tournaisian (Ivorian) of Flavion, Maredsous and Sosoye (Waulsort Formation and/or Les Avins Member (Longpré
Formation); see Section 6.1.1.) and from the Viséan (Anhée Formation, Warnantian) of Warnant (Fig. 2);

Nicely preserved invertebrates from the historical type areas (Tournai and Visé) of the Tournaisian and Viséan stages;

Conodonts from the Tournaisian succession of the Maredsous area (Ghysens \& Conil, 1973);

One rostrum of an unidentified Ichthyosauria (Fig. 5K) from the Lower-Middle Jurassic (Toarcian-Bajocian) of the Belgian Lorraine (Halanzy);

Some vertebrate remains (sharks, mosasaurs, teleostean fishes (Fig. 5I-J)) from the Coniacian (?)-basal Campanian (?) Lonzée Member of the Lonzée area, near Gembloux.

\section{Comments on Devonian and Carboniferous brachiopods and trilobites originally described in southern Belgium}

\subsection{Preliminary remarks}

\subsubsection{Stratigraphical comments}

Many brachiopod species and varieties were introduced by Demanet (1923) for specimens originating from Maredsous (disused lime kiln quarry, known as the 'carrière du four à chaux' in the Belgian literature) and Sosoye. The reader is referred to Fournier (1892, 1896b), Demanet (1923), and Delcambre \& Pingot (2018) for more details concerning these major sections (Fig. 1). Besides the fact that the type specimens were very poorly illustrated in the original publication, it appears that the Sosoye material comes from two distinct stratigraphic levels, namely the Waulsort Formation and the Avins Member (Longpré Formation) (Fig. 2) according to E. Poty (pers. com., February 2020). Both units are of Ivorian age, but the Avins Member (just few metres) capped the Waulsortian buildups (e.g., Poty, 2016). However, it is virtually impossible to ascertain the stratigraphic level in the absence of matrix as is case of most of the specimens present in the collections. In contrast to Sosoye, all the specimens from the disused lime kiln quarry at Maredsous come from the Waulsort Formation.

The type locality and horizon of the brachiopod species and varieties (see comments below) from the Tournai area (Fig. 1) described by Demanet (1934) often remain obscure and some of them were overlooked in the overview published by Demanet (1958). This author indicated 'Assise de Celles' (Fig. 2) as the type horizon for his new species and varieties. Nowadays, this disused stratigraphic unit encompasses two lithostratigraphic ones, from base to top: the Tournai (Hastarian-Ivorian) and Antoing (including the Warchin Member; Ivorian) formations (Poty et al., 2002; Hance et al., 2006a).

\subsubsection{Taxonomical comments}

According to the article 45.6 .4 of the International Code of Zoological Nomenclature (1999), the epithets, which were used for the orthide, productide and spiriferide varieties introduced by Demanet (1923), must be considered as of subspecific rank in his publication.

In spite of the efforts made, it was not possible to locate more syntypes (unless specifically explained) than those illustrated by Demanet (1923), which are all curated at the RBINS. The search for additional specimens belonging to Demanet's collections in those of the Université de Liège were fruitless as was the case of the search for additional chonetidine and rhynchonellide specimens that were studied by Ch. Fraipont (1908). Consequently, unless it was clearly or implicitly exposed by Demanet (1923), it is impossible to state if the only specimen illustrated corresponds to the holotype by monotypy. 


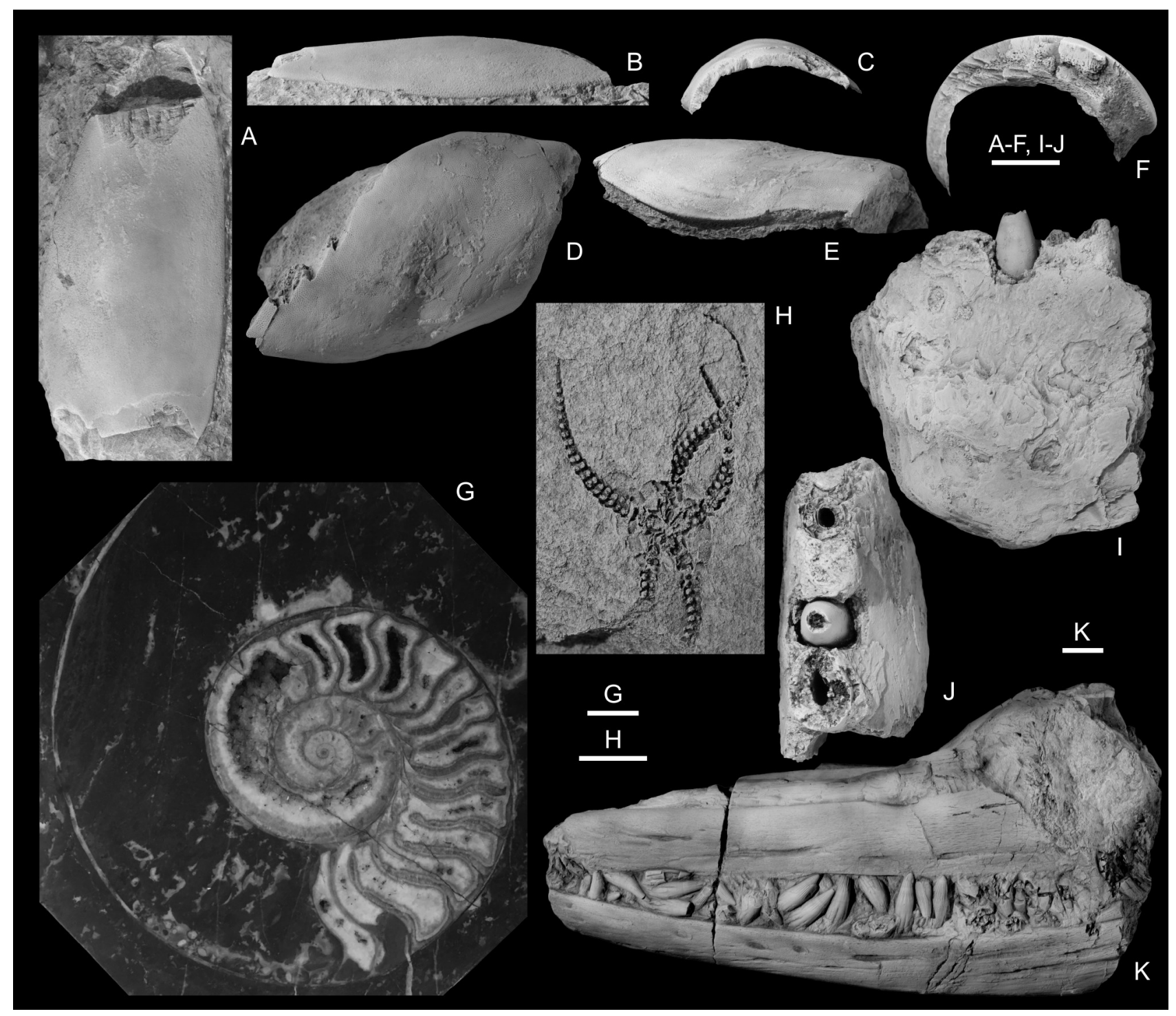

Figure 5. A-C. Sandalodus morrisi Davis, 1883, CGF 2020.11.10/14, posterior dental plate in oral, labial, and mesial views; Yvoir, Landelies Formation (Tournaisian, Hastarian). D-F. Deltodus robustus (de Koninck, 1878), CGF 2020.11.10/15, posterior dental plate in oral, lingual and mesial views; Ermeton-sur-Biert, Hastière Formation or Landelies Formation (Tournaisian, Hastarian). G. Manticoceras? sp., CGF 2020.11.10/16, longitudinal section; Vodelée (?), Neuville Formation or Les Valisettes Formation, Petit-Mont Member (late Frasnian). H. Ophiaulax decheni (Dewalque, 1881), CGF 2020.11.10/17, internal mould; Ratingen area (Germany, Velbert Anticline), Velbert Formation (late Famennian). I-J. Fragment of a lower (?) jaw of an unidentified teleostean fish, CGF 2020.11.10/18, lateral and oclusal views; Lonzée, Lonzée Member (Coniacian?basal Campanian?). K. Rostrum of an unidentified Ichthyosauria, CGF 2020.11.10/19, left lateral view; Halanzy area (Toarcian-Bajocian). Scale bars: $10 \mathrm{~mm}(\mathrm{~A}-\mathrm{F}, \mathrm{I}-\mathrm{J}, \mathrm{K}), 25 \mathrm{~mm}(\mathrm{G}), 2.5 \mathrm{~mm}(\mathrm{H})$.

We have thus proceeded to lectotype selection for the species described by Ch. Fraipont (1908) and for most of those of Demanet (1923).

Concerning the syntypes (thus the paralectotypes if a lectotype was previously selected) of the brachiopod species erected by Demanet (1934) curated at the RBINS, only the specimens illustrated in the original papers have been considered, but it is evident that others should be regarded as such. Nonetheless, the screening of the whole RBINS collections for the search for additional syntypes would have been a too timeconsuming task for all the species discussed in this paper, and thus remains to be done. Similar remarks apply to the trilobite taxa introduced by Stainier (1887) and Richter \& Richter (1933).

It clearly appears that many brachiopod species were erected based on insufficiently preserved specimens or are only known by a very restricted material (sometimes only one specimen is available). Had these species not been given a name, the present writer would have left them in open nomenclature.

Several species, which were erected on the basis of Belgian material, appear to be primary homonyms of anteriorly published ones. They are not renamed in this paper because they are considered as nomina dubia due to the limited material available, which is generally poorly preserved.

In an overview of the uppermost Famennian (Strunian)Viséan invertebrate faunas from southern Belgium, Demanet (1958) introduced one new brachiopod genus (Orbiculoipora, with no type species selected), several new species (Chonetes (Semenewia) verbisti, Productus (Avonia) humilis, Productus (Pustula) tenuissimus, Derbya modavensis, Hustedia parva, Crurithyris sulcata [non C. sulcata Stehli, 1954], Spirifer fallax [non Sp. fallax Giebel, 1858]) and one new variety (Schizophoria resupinata var. transversalis) in his faunal lists. These names were used later by Mortelmans (1969, 1973). 
Nevertheless, as noted by Mottequin \& Sevastopulo (2009) and Mottequin \& Simon (2017a) for Crurithyris sulcata Demanet, 1958 , they have to be considered as nomina nuda, according to the article 13 of the International Code of Zoological Nomenclature (1999), as Demanet (1958) failed to provide a description or a definition of his new genus, species and variety.

Two productidine species described by de Koninck (1847) are discussed below as one of them (Productus dissimilis) was overlooked by Mottequin (2019) whereas the second ( $P$. murchisonianus) was based originally on material from Western Europe (e.g., Belgium, Germany) and Australia (Tasmania).

\subsection{Upper Devonian and Carboniferous brachiopods}

\subsubsection{Orders Lingulida and Craniida/Remarks}

Representatives of the orders Lingulida and Craniida have always been the poor relations of the studies on Devonian and Carboniferous brachiopods from southern Belgium, notably due to their scarcity in most of the lithostratigraphic units. Demanet's (1934) monograph should be thus considered as an exception as he described and photographically illustrated or discussed several lingulides and craniides, including some of those erected by de Koninck (1843 in 1842-1844), de Ryckholt (1851), and J. Fraipont (1888a, 1888b), from the Tournaisian and Viséan succession of the Namur-Dinant Basin. Some of these species were recently illustrated by Mottequin \& Simon (2017a, 2017b) and Mottequin et al. (2019), but they are still unrevised. The focus is put here on the type material of the lingulide species erected by J. Fraipont (1888a), Demanet (1934), Demanet (in Demanet \& Van Straelen, 1938), and Grimm (1998). The re-illustration of Demanet's material should facilitate a future revision of the Mississippian and Pennsylvanian lingulides of Western Europe (see previous references in Mottequin et al., 2019 and herein), but this latter aspect is not tackled. Consequently, the Devonian and Carboniferous lingulide species from southern Belgium previously assigned to the 'catch-all' genus Lingula Bruguière, 1797 still need revised identifications to genera (requiring observations of the internal structures) and their validity is not discussed here. Demanet (1958) and Mortelmans (1969, 1973) provided information related to the stratigraphic distribution of the lingulides within the Tournaisian succession of the Tournai area, but the revision of these data is still outstanding (Mottequin \& Simon, 2017a, 2017b).

De Ryckholt (1851, p. 17, 167, pl. 10, figs 21-23) erected the genus Anomianella (with Anomianella proteus as type species, by monotypy) based on material from the Tournaisian succession of Tournai (Fig. 1) and it was only three years later that he provided a description (de Ryckholt, 1854, p. 45-47). This genus was considered as a bivalve of the Family Anomiidae (Stoliczka 1870-1871; Vokes 1967, 1980) and was sporadically cited in the literature (e.g. Crosse, 1863; Rosenberg \& Petit, 1987). Although it is currently only known by de Ryckholt's (1851) drawings because specimens identified as such have not yet been traced in de Ryckholt's collections, it is more plausible to consider Anomianella as a craniide brachiopod for several reasons (as already suggested by de Ryckholt, 1854, p. 46, footnote): (1) the specimens are fixed by their ventral valve on brachiopods and molluscs, and (2) they have the faculties to imitate the ornamentation of their host. Based on these data, the resemblances with Petrocrania Raymond, 1911 (Craniidae) are striking, and both genera might be closely related, if not identical. Furthermore, de Ryckholt (1854) indicated that Anomianella is represented by many species in the Devonian and the Carboniferous of Belgium. According to our knowledge of the Belgian material, only craniides match with de Ryckholt's $(1851,1854)$ description and illustrations. Nonetheless, it is more reasonable to currently consider Anomianella as a nomen dubium pending further investigation, notably the revision of the Tournaisian craniides from Tournai (see recent illustrations in Mottequin \& Simon, 2017a, fig. 12g-h, and 2017b, fig. 6).

\subsubsection{Order Lingulida/Superfamily Linguloidea}

Lingula elongata Demanet (in Demanet \& Van Straelen, 1938), non Hall, 1847

(Fig. 6A-E)

1938 Lingula elongata Demanet in Demanet \& Van Straelen, p. 117, pl. 107, figs 14-17.

1941 Lingula elongata Demanet; Demanet, p. 212-213, 294, 296, pl. 12, figs 5-8 (enlargement of Demanet in Demanet \& Van Straelen, pl. 107, figs 14-17).

Type material. No lectotype is designated among the four syntypes (RBINS a6379-6382; undifferentiated valves; Fig. 6AE) illustrated by Demanet (in Demanet \& Van Straelen, 1938) and re-illustrated few years later by Demanet (1941).

Provenance and horizon. The syntypes are from Nalinnes 1 , the Aiseau-Presles colliery and Montignies-le-Tilleul (Forte Taille colliery) (Fig. 1). According to Demanet (1941), this species is only known from the Andenne Formation (latest Serpukhovian to early Bashkirian; Namurian B-C of the traditional subdivision).

Description. See Demanet (in Demanet \& Van Straelen, 1938) and Demanet (1941).

Remarks. As rightly indicated by Calver (in Lumsden et al., 1967) and Graham (1970), Lingula elongata Hall, 1847 (from the Upper Ordovician Trenton Group) and L. elongata Demanet, 1934 are primary homonyms (articles 53.3, 57.2 of the Code) (see also Graham's (1970) discussion related to Tate's intention of naming L. elongata some specimens from the Lower Carboniferous of Northumberland that were briefly discussed in Davidson, 1860). Considering the poor preservation of the illustrated syntypes and their different origins, it is currently more reasonable to opt for the status quo pending the revision of the lingulides from the Belgian Coal Measure Group and to not propose a new name to solve the homonymy with Hall's species. Note that specimens identified as L. elongata were figured by Van Leckwyck et al. (1951) and Deleers \& Pastiels (1952).

Current name. 'Lingula' elongata Demanet (in Demanet \& Van Straelen, 1938), non Hall, 1847.

\section{Lingula maillieuxi Grimm, 1998}

(Fig. 6F-G)

1940a Lingula n. sp. Maillieux, p. 8.

1998 Lingula maillieuxi Grimm, p. 75-76, 82, pl. 1, fig. 4.

Type material. The holotype (a ventral valve (?); RBINS 1705) selected by Grimm (1998, pl. 1, fig. 4) is the only specimen available (Fig. 6F-G).

Type locality and horizon. Couvin 40a (Figs 1-2), Nismes Formation (La Prée Member) (early Frasnian).

Description. See Grimm (1998).

Remarks. The anterior part of the holotype was not illustrated by Grimm (1998) and details of the ornamentation are provided here for the first time (Fig. 6G). Lingulides from the Upper Devonian of southern Belgium have received scant attention until so far (see Mottequin, 2019), although they are abundant in some poorly oxygenated, argillaceous 


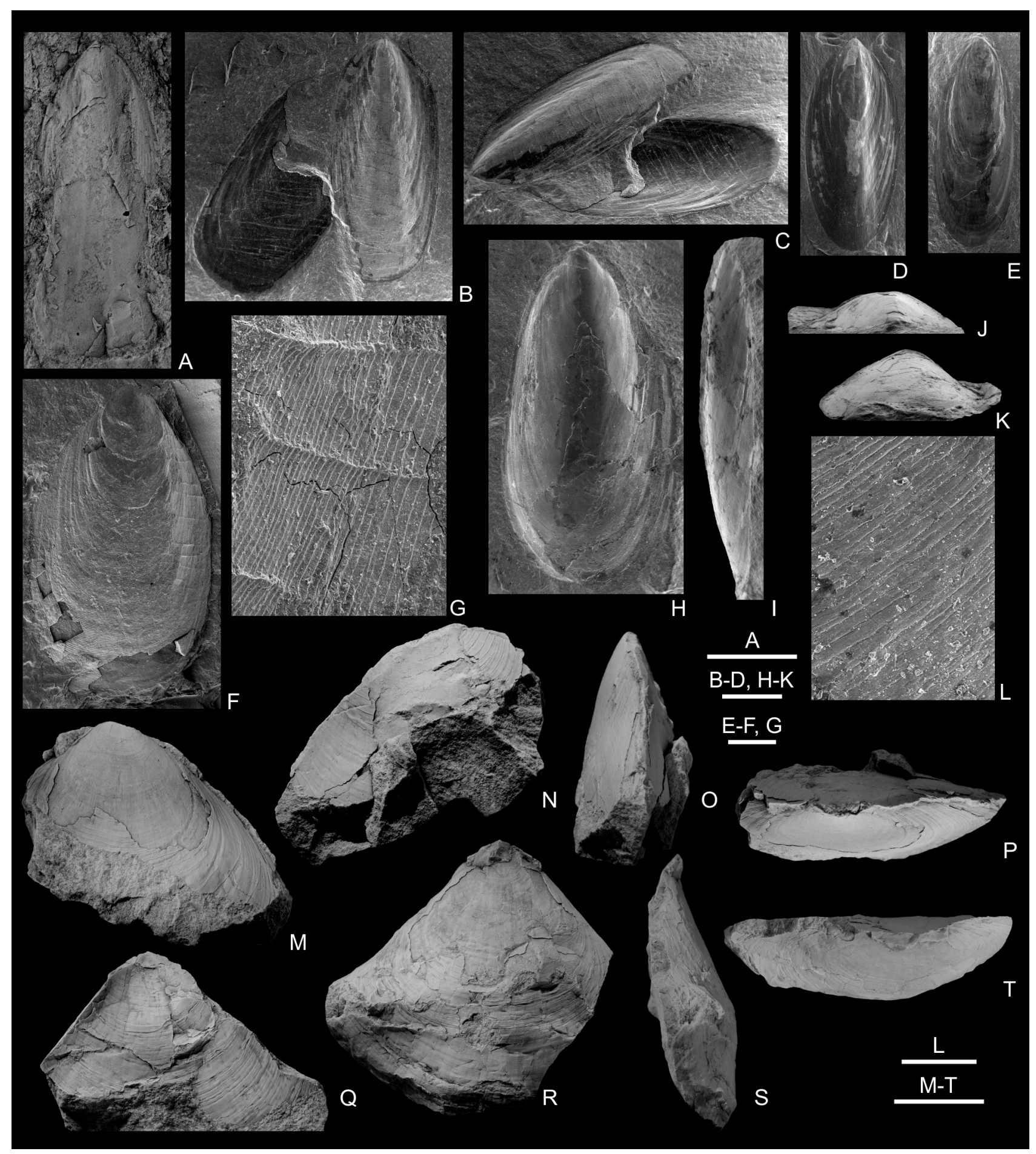

Figure 6. A-E. Lingula elongata Demanet (in Demanet \& Van Straelen, 1938), non Hall, 1847 [ 'Lingula' elongata Demanet (in Demanet \& Van Straelen, 1938), non Hall, 1847]; syntypes. A. RBINS a6379, undifferentiated valve in plan view; Nalinnes 1, Andenne Formation (?) (Namurian?). B-C. RBINS a6380, articulated specimen in plan and oblique lateral views (SEM); Montignies-le-Tilleul, Forte Taille colliery (Espinoy shaft), Andenne Formation (Namurian). D. RBINS a6381, undifferentiated valve (SEM), Aiseau-Presles colliery (Panama shaft, Roselies), stage $560 \mathrm{~m}$ above the Gouffre fault, $125 \mathrm{~m}$ south of the shaft, Andenne Formation (Namurian). E. RBINS a6382, undifferentiated valve (SEM); same provenance and age than RBINS a6380. F-G. Lingula maillieuxi Grimm, 1998 [ 'Lingula' maillieuxi Grimm, 1998], RBINS a1705 (holotype), ventral valve (?) in plan view and detail (SEM); Couvin 40a, Nismes Formation, La Prée Member (early Frasnian). H-L. Lingula straeleni Demanet, 1934 ['Lingula' straelen Demanet, 1934], RBINS a5802 (lectotype), undifferentiated valve in plan, lateral, posterior and anterior views, and close-up of the ornamentation (SEM); Tournai area, Tournaisian (precise origin and lithostratigraphic unit unknown). M-T. Trigonoglossa tornacensis Demanet, 1934; Antoing 3, Tournai Formation (Tournaisian). M-P. RBINS a5806 (lectotype), incomplete articulated specimen in ventral, dorsal, lateral and posterior views. Q-T B RBINS a5807 (paralectotype), incomplete articulated specimen in dorsal, ventral, lateral and posterior views. Scale bars: $5 \mathrm{~mm}$ (A), $2 \mathrm{~mm}$ (B-D, H$\mathrm{K}), 1 \mathrm{~mm}(\mathrm{E}-\mathrm{F}), 100 \mu \mathrm{m}(\mathrm{G}), 200 \mu \mathrm{m}(\mathrm{L}), 10 \mathrm{~mm}(\mathrm{M}-\mathrm{T})$. 
environments, notably within the upper Frasnian Matagne Formation (e.g., Mottequin \& Poty, 2016) in which Grimm (1998) recognized representatives of the genus Dignomia Hall, 1871.

Current name. 'Lingula' maillieuxi Grimm, 1998.

\section{Lingula straeleni Demanet, 1934}

(Fig. 6H-L)

1934 Lingula straeleni Demanet, p. 14-15, 104, pl. 1, figs 45 , text-fig. 1.

2019 'Lingularia' straeleni (Demanet, 1934); Mottequin et al., p.10, fig. 6.7-22.

Type material. Mottequin et al. (2019) selected the lectotype (RBINS a5802 (Fig. 6H-L); Demanet, 1934, pl. 1, fig. 5; Mottequin et al., 2019, fig. 6.14-17) among the specimens considered by Demanet (1934) as paratypes. The specimens RBINS a5801 (Demanet, 1934, pl. 1, fig. 4; Mottequin et al., 2019, fig. 6.7-13) and RBINS a5803 (Demanet, 1934, text-fig. 1; Mottequin et al., 2019, fig. 6.18-22) are paralectotypes.

Type locality and horizon. Tournai area, 'Assise de Celles' (Tournaisian) (Demanet, 1934) (see Mottequin et al.'s (2019) discussion concerning the type horizon) (Figs 1-2).

Description. See Demanet (1934).

Remarks. See Mottequin et al.'s (2019) discussion.

Current name. 'Lingula' straeleni (Demanet, 1934).

Trigonoglossa tornacensis Demanet, 1934

(Fig. 6M-T)

1934 Trigonoglossa tornacensis Demanet, p. 19-20, 104, pl. 1, figs 8-9.

Types. The articulated but crushed specimens RBINS a5806 (Demanet, 1934, pl. 1, fig. 8) and RBINS a5807 (Demanet, 1934, pl. 1, fig. 9) were considered as paratypes by Demanet (1934), who did not select a holotype. The specimen RBINS a5806 (Fig. 6M-P) is hereby designated as the lectotype. The specimen RBINS a5807 (Fig. 6Q-T) is thus a paralectotype.

Type locality and horizon. Antoing 3 (= La Chapelle quarry in Demanet, 1958), 'Assise de Celles' (Demanet, 1934) (Figs 12). According to Mortelmans (1969), the species would be only known from the Tournai Formation (upper part of the Allain Member; Tournaisian, Ivorian).

Description. See Demanet (1934).

Remarks. According to Winkler Prins \& Amler (2006), Trigonoglossa tornacensis is probably a synonym of $T$. scotica (Davidson, 1860) from the Viséan-Serpukhovian of Scotland (Graham, 1970). The poor state of preservation of Demanet's (1934) material precludes at this stage to confirm (or otherwise) this opinion, although both specimens available seem to be more developed in width.

Current name. Trigonoglossa tornacensis Demanet, 1934.

\subsubsection{Order Lingulida/Superfamily Discinoidea}

Orbiculoidea ingens Demanet (in Demanet \& Van Straelen, 1938)

(Fig. 7A-C)

1938 Orbiculoidea ingens Demanet (in Demanet \& Van Straelen), p. 118, pl. 107, figs 18-19.

1941 Orbiculoidea ingens Demanet: Demanet, p. 214, pl. 12, figs 13-14 (enlargement of Demanet in Demanet \& Van Straelen, 1938, pl. 107, figs 18-19).
Type material. The dorsal valve RBINS a6384 (Demanet in Demanet \& Van Straelen, 1938, pl. 107, fig. 19; Demanet, 1941, pl. 12, fig. 13) is hereby designated as the lectotype (Fig. 7A) whereas the second dorsal valve RBINS a6383 (Demanet in Demanet \& Van Straelen, 1938, pl. 107, fig. 18; Demanet, 1941, pl. 12, fig. 14) is a paralectotype (Fig. 7B-C).

Type locality and horizon. Montignies-le-Tilleul (Fig. 1), Forte-Taille colliery, Espinoy shaft (see Demanet, 1941 for more details), upper part of the Andenne Formation (Bashkirian, Namurian C of the traditional subdivision).

Description. See Demanet (in Demanet \& Van Straelen, 1938), Demanet (1941).

Remarks. The type material is poorly preserved and crushed, thus unsuitable for species description. According to the data provided by Demanet (1941), this species is recognized in Belgium within the Andenne Formation (latest Serpukhovian to early Bashkirian; Namurian $\mathrm{A}-\mathrm{C}$ of the traditional subdivision). The species was reported in Germany (e.g., Schwarzbach \& Reichelt, 1940) and in Poland (Korejwo \& Teller, 1968), and doubtfully in the Netherlands (Dorsman, 1945).

Current name. Orbiculoidea ingens Demanet (in Demanet \& Van Straelen, 1938).

\section{Discina (Orbiculoidea) multistriata J. Fraipont, 1888a}

(Fig. 7D-F)

1875 Discinia [sic] nitida ? Phillips; Dewalque, p. 119.

1888a Discina (Orbiculö̈dea [sic]) multistriata J. Fraipont, p. 162-164, unnumbered figures.

1934 Orb. [= Orbiculoidea $]$ multistriata; Demanet, p. 25.

Type material. The incomplete, crushed dorsal valve (and its external mould) (ULg.PA.2020.07.13/1; Fig. 7D-F) illustrated by $\mathrm{J}$. Fraipont (1888a, unnumbered and embellished figures) is hereby designated as the holotype by monotypy.

Type locality and horizon. Vierset (Royseux section; Fig. 1), Comblain-au-Pont Formation (latest Famennian, Strunian).

Description. See J. Fraipont (1888a), who interpreted the holotype as a ventral valve. He mentioned that a fusiform slit was developed in an infundibuliform excavation (i.e. the apical region), from the centre towards the posterior margin, and that two small circular muscular impressions were developed on both sides of this slit. A careful examination indicates that all these features are the results of deficient preservation.

Remarks. Although this species was overlooked by Mottequin (2019), it is the only discinid described from the uppermost Famennian (Strunian) of the Namur-Dinant Basin and should be thus added to Mottequin \& Brice's (2016) review of Strunian brachiopods from this area. Note that Dehée (1929) did not report discinids in the contemporaneous succession of the Avesnois (northern France), but Mortelmans (1969) reported the occurrence of representatives of the genus Orbiculoidea d'Orbigny, 1847 within the Etrœungt Formation (Tournai area). Nevertheless, J. Fraipont's species remains inadequately known (see also remarks related to Orbiculoidea portlockiana Demanet, 1934).

Current name. Orbiculoidea multistriata (J. Fraipont, 1888a).

Orbiculoidea portlockiana Demanet, 1934

(Figs 7G-T, 8A-C)

1934 Orbiculoidea portlockiana Demanet, p. 24-26, 104, pl. 1, figs $14-17$, text-fig. 6 .

Type material. Demanet (1934) illustrated four specimens 


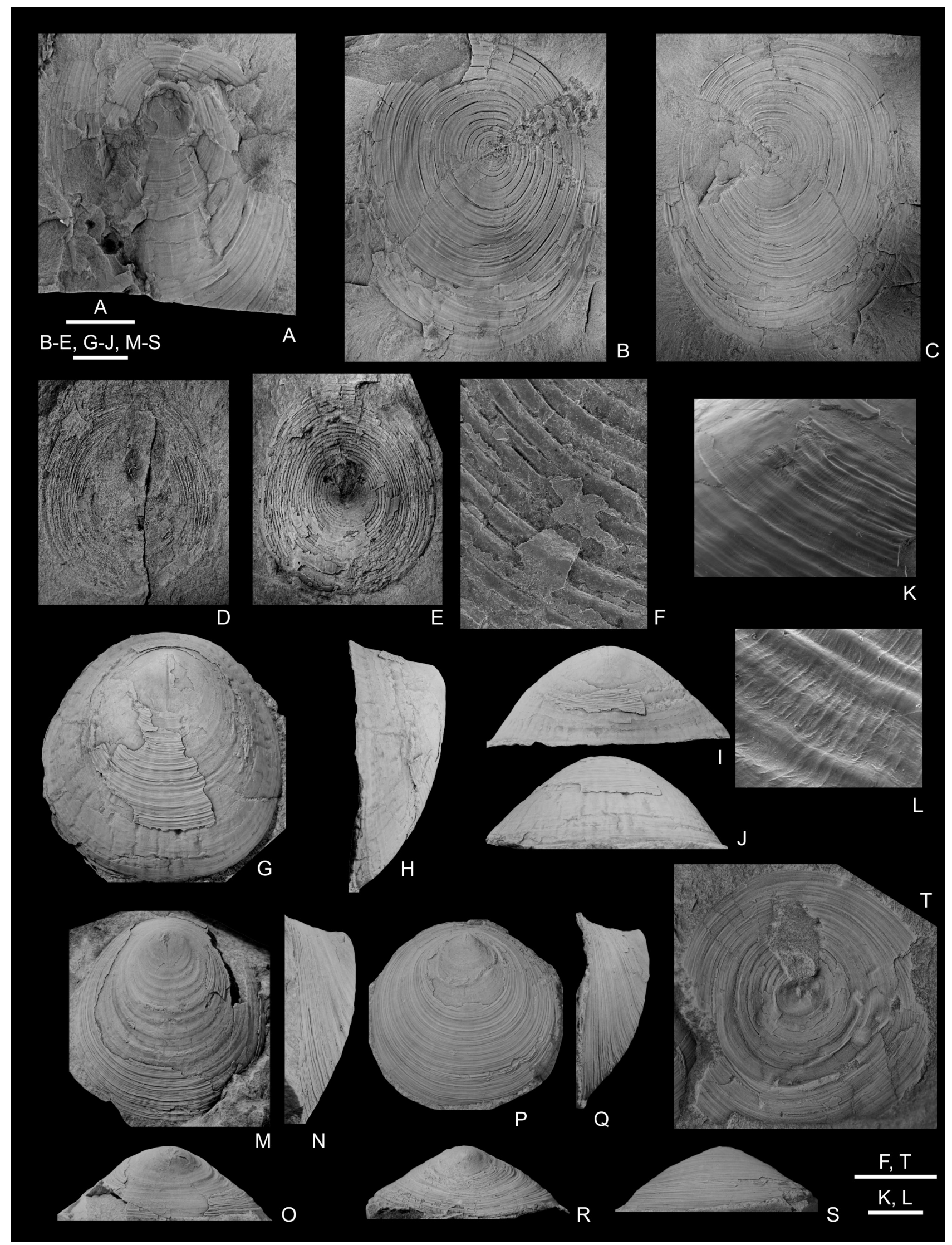

Figure 7. A-C. Orbiculoidea ingens Demanet (in Demanet \& Van Straelen, 1938); Montignies-le-Tilleul, Forte-Taille colliery, Espinoy shaft, upper part of the Andenne Formation (Bashkirian, Namurian C of the traditional subdivision). A. RBINS a6384 (lectotype), crushed dorsal valve. B-C. RBINS a6383 (paralectotype), flattened dorsal valve and external mould. D-F. Discina (Orbiculoidea) multistriata J. Fraipont, 1888a [Orbiculoidea multistriata (J. Fraipont, 1888a)], ULg.PA. 2020.07.13/1 (holotype by monotypy), incomplete, crushed dorsal valve and external mould; Vierset (Royseux section), Comblain-au-Pont Formation (latest Famennian, Strunian). G-T. Orbiculoidea portlockiana Demanet, 1934; Tournai area, 'Assise de Celles' (Tournaisian). G-L. RBINS a5814 (lectotype), dorsal valve in plan, lateral, posterior and anterior views, and detail (SEM) of the radial striae developed on inner shell layers. M-O. RBINS a5815 (paralectotype), incomplete dorsal valve in plan, lateral and posterior views. P-S. RBINS a5817 (paralectotype), dorsal valve in plan, lateral, posterior and anterior views. T. RBINS a5816 (paralectotype), external mould of a ventral valve. Scale bars: 5 mm (A, B-E, G-J, M-S, T), 1 mm (F, K), $250 \mu \mathrm{m}$ (L). 
(three dorsal valves and one external ventral mould) that he considered as paratypes (without selecting a holotype): RBINS a5814 (pl. 1, fig. 14, text-fig. 6; Fig. 7G-L), RBINS a5815 (pl. 1, fig. 15, not text-fig. 6 as wrongly indicated; Fig. 7M-O), RBINS a5816 (pl. 1, fig. 16; Fig. 7T), and RBINS a5817 (pl. 1, fig. 17; Figs 7P-S, 8A-C). The specimen RBINS a5814 is hereby designated as the lectotype, the other specimens should be thus considered as paralectotypes.

Type locality and horizon. Tournai area, 'Assise de Celles' (Demanet, 1934) (Figs 1-2). Mortelmans (1969) reported the species in the Tournai (Crampon (Hastarian or Ivorian)), Pont-à-Rieu, and Vaulx members (both latter are Ivorian in age) and in the Antoing (Warchin Member of Ivorian age) formations.

Description. See Demanet (1934). Not all fila are continuously traceable, and they sometimes form outwardly convex drapes (e.g., Fig. 7M). Detail of the radial arrays of pits observed on the surface of the dorsal valve, which are similar to those observed in Orbiculoidea nitida (Phillips, 1836) by Williams \& Curry (1991), is provided in Fig. 8A-C. Demanet (1934, text-fig. 6) illustrated the thin radial striae observed on the lectotype (Fig. 7K-L) and extrapolated their presence on the whole shell. However, they are only developed on the inner shell layers.

Remarks. Demanet (1934) considered Orbiculoidea multistriata (J. Fraipont, 1888a) (see above) as a doubtful synonym (!) of $O$. portlockiana, but the deplorable state of knowledge concerning J. Fraipont's species precludes further discussion. Graham (1972) considered O. portlockiana as a junior synonym of $O$. cincta (Portlock, 1843) from the upper Viséan of Benburb in Co. Tyrone (Northern Ireland) (Mitchell \& Mitchell, 1982). This author selected a lectotype for Portlock's species but noted that it was not traced. To our knowledge, there is no recent illustration of topotypes of $O$. cincta, but comparison with Portlock's (1843) drawings shows that the dorsal apex is clearly more posteriorly located in $O$. portlockiana than in the North Irish species. Note also that Řehoř \& Řehořová (1972) erected a subspecies (Orbiculoidea portlockiana namuriana) based on material from the former Czech Republic.

Current name. Orbiculoidea portlockiana Demanet, 1934.

\section{Orbiculoidea tornacensis Demanet, 1934}

(Fig. 8D-H)

1934 Orbiculoidea tornacensis Demanet, p. 26-27, 104, pl. 1, fig. 18 , text-fig. 7 .

Type material. The dorsal valve RBINS a5818 (Fig. 8D-H) was selected as the holotype by Demanet (1934, pl. 1, fig. 18, text-fig. 7).

Type locality and horizon. Antoing 3 (= La Chapelle quarry in Demanet, 1958), 'Assise de Celles' (Tournaisian) (Demanet, 1934) (Figs 1-2). Mortelmans (1969) reported the species in the Orient (?) (Hastarian), Tournai (Crampon (Hastarian or Ivorian), Allain, Pont-à-Rieu, and Vaulx members (the latter three are Ivorian in age)) and in the Antoing (Warchin Member of Ivorian age) formations.

\section{Description. See Demanet (1934).}

Remarks. Although Graham (1972) considered Orbiculoidea tornacensis as a junior synonym of $O$. cincta (Portlock, 1843), the remark already expressed for $O$. portlockiana (see above) is still valid in this case but it is only based on the holotype of the species tornacensis. Further material is obviously needed for an accurate comparison. Orbiculoidea tornacensis was reported on several occasions in the Lower Carboniferous of Poland (Holy Cross Mountains,
Pomerania) (e.g., Kicuła \& Żakowa, 1966; Korejwo, 1979; Żakowa \& Chlebowski, 1984) and these records should be revised in the future.

Current name. Orbiculoidea tornacensis Demanet, 1934.

\section{Roemerella maillieuxi Demanet, 1934}

(Fig. 8I-Q)

1934 Roemerella maillieuxi Demanet, p. 27-28, 104, pl. 1, figs 19,19 a, text-figs $8,8 \mathrm{a}, 8 \mathrm{~b}$.

Type material. The incomplete, articulated specimen RBINS a5819 (Demanet, 1934, pl. 1, fig. 19-19a, text-fig. 8, 8a-b; Fig. 8I-Q) was selected as the holotype by Demanet (1934).

Type locality and horizon. Tournai area, 'Assise de Celles' (Demanet, 1934) (Figs 1-2). No more information was provided by Demanet (1958) and Mortelmans (1969).

Description. See Demanet (1934). Pitted microornament homogeneously developed was observed on the ventral valve of the holotype (Fig. 8P-Q).

Remarks. Mottequin's (2019) comment made for the Devonian species Roemerella forrierensis Maillieux, 1932 is valid concerning the generic assignment of Demanet's species.

Current name. Roemerella maillieuxi Demanet, 1934.

\subsubsection{Order Productida/Suborder Chonetidina}

Chonetes parva Ch. Fraipont, 1908, non Shumard, 1855

(Fig. 9A-B) $2 \mathrm{a}-\mathrm{b}$.

1908 Chonetes parva Ch. Fraipont, p. M10-M11, pl. 4, fig.

Type material. The external mould of a minute dorsal valve (ULg.PA. 2020.07.13/2) with some shelly fragments illustrated by Ch. Fraipont (1908) is hereby designated as the lectotype (Fig. 9A-B).

Type locality and horizon. Flavion (Fig. 1); according to Ch. Fraipont (1908), this species is known from the 'Waulsortien', which corresponded in those days to the Waulsortian facies (Tournaisian). The matrix is a dark limestone (mudstone) that could be from the Leffe Formation (Tournaisian, Ivorian) or even from the Molignée Formation (Viséan, Moliniacian) (Fig. 2).

Description. See Ch. Fraipont (1908).

Remarks. Chonetes parva Shumard, 1855 from the Coal Measures of Boone County (USA, Missouri) and Chonetes parva Ch. Fraipont, 1908 are primary homonyms (Articles 53.3, 57.2 of the Code). Shumard's species was not illustrated in the original publication and was considered as a synonym of Chonetes flemingi Norwood \& Pratten (1854) - the type species of Chonetinella Ramsbottom, 1952-by Keyes (1894). Although the part 1 of the volume 3 (second series) of the Journal of the Academy of Natural Sciences of Philadelphia, which includes the description of $C$. flemingi, was released in May, 1855, extra copies were printed for the authors in August, 1854; thus, following the Article 21.8 of the Code, 1854 is the year of publication. Shumard's species was published at the end of the year 1855 according to Shumard's report dated November, 1855. According to the Article 57.2, the junior name, i.e. Chonetes parva Ch. Fraipont, 1908, is permanently invalid and should be renamed but, due to the lack of additional specimens, no new name is currently proposed pending the thorough study of the Tournaisian-Viséan chonetidines from southern Belgium, which is well beyond the scope of this paper. Delépine (1928), who studied the brachiopod fauna from the Molignée Formation, did not report this species. From the 


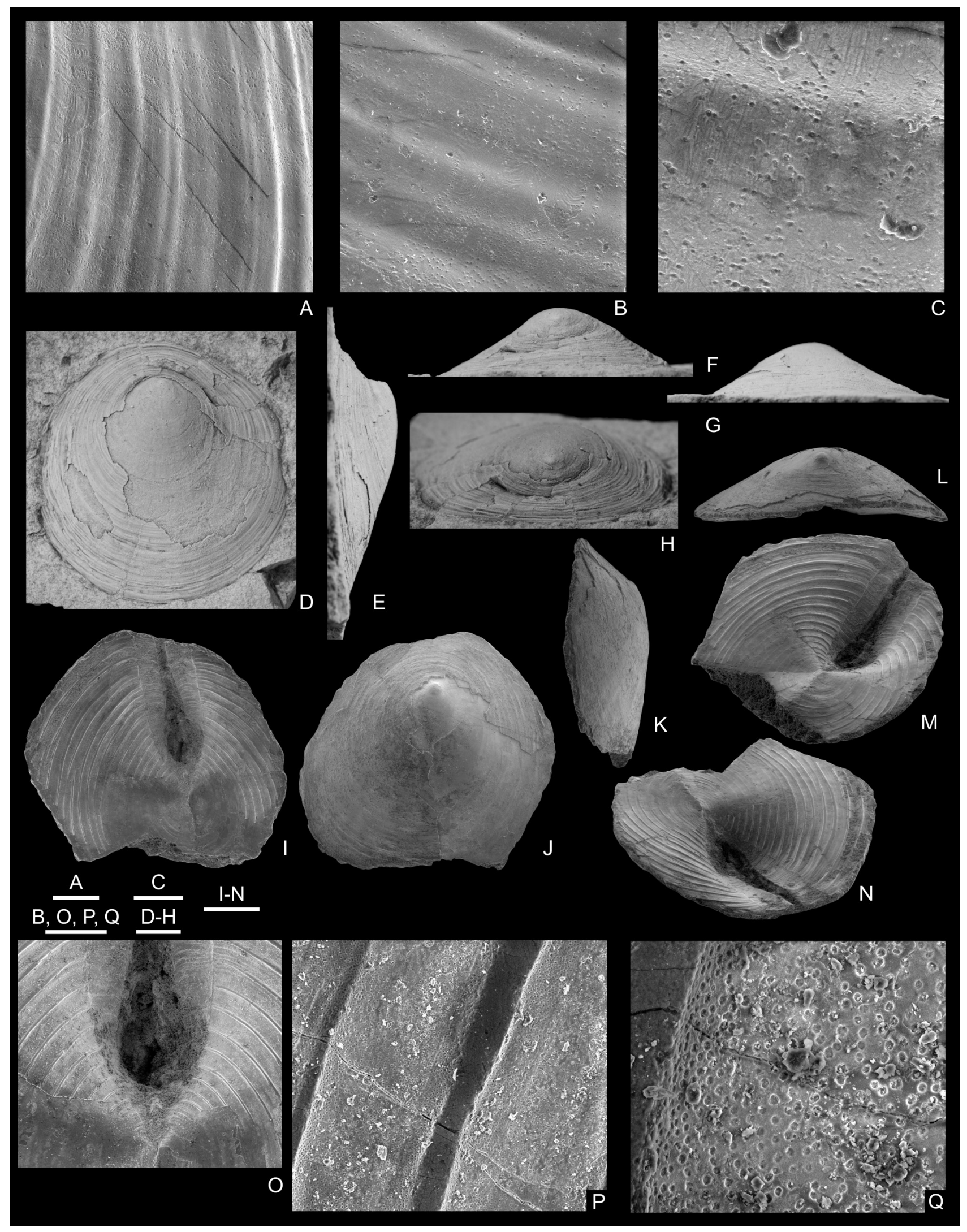

Figure 8. A-C. Orbiculoidea portlockiana Demanet, 1934, RBINS a5817 (paralectotype), dorsal valve (see Fig. 7P-S), detail of pitted microornament close to the anterior margin (all SEM); Tournai area, 'Assise de Celles' (Tournaisian). D-H. Orbiculoidea tornacensis Demanet, 1934, RBINS a5818 (holotype), dorsal valve in plan, lateral, posterior, anterior, and inclined posterior views; Antoing 3, 'Assise de Celles' (Tournaisian). I-Q. Roemerella maillieuxi Demanet, 1934, RBINS a5819 (holotype), incomplete articulated specimen in ventral, dorsal, lateral, posterior, oblique ventral, and oblique posteroventral views, partial enlargement of the pedicle opening, and detail of pitted microornament on ventral valve (all SEM); Tournai area, 'Assise de Celles' (Tournaisian). Scale bars: $250 \mu \mathrm{m}$ (A), $200 \mu \mathrm{m}$ (B, P), $50 \mu \mathrm{m}$ (C, Q), 2 mm (D-H, I-N), 1 mm (O). 


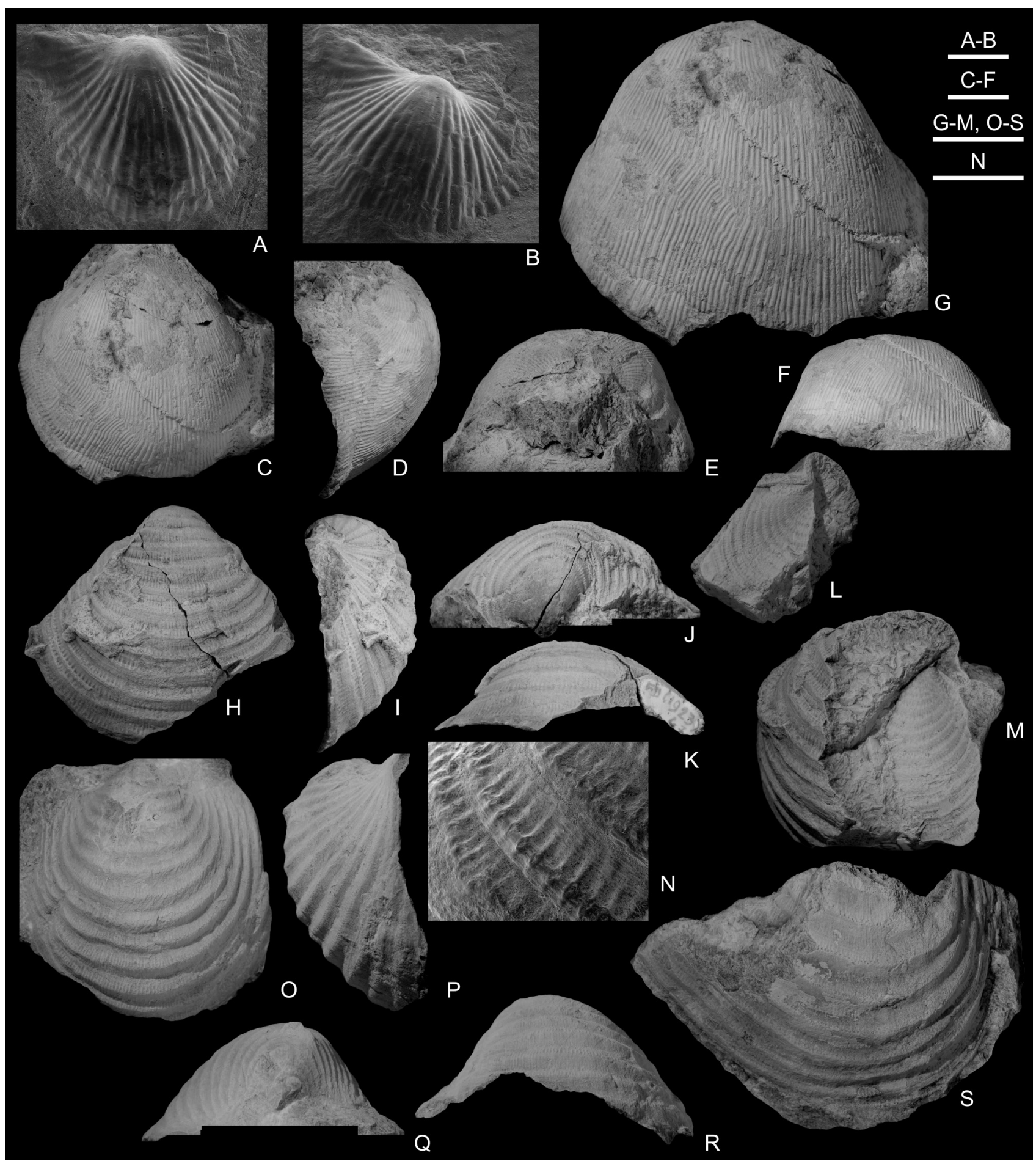

Figure 9. A-B. Chonetes parva Ch. Fraipont, 1908, non Shumard, 1855 ['Chonetes' parvus Ch. Fraipont, 1908, non Shumard, 1855], ULg.PA. 2020.07.13/2 (lectotype), dorsal external mould in plan and lateral oblique views (SEM); Flavion, Leffe Formation (Tournaisian, Ivorian) or Molignée Formation (Viséan, Moliniacian). C-G. Productus corrugatus var. contortus Demanet, 1923 [Linoprotonia? contorta (Demanet, 1923)], RBINS a11777 (lectotype), incomplete ventral valve in plan, lateral, posterior and anterior views, and detail of the ornamentation; Maredsous, Waulsort Formation (Tournaisian, Ivorian). H-S. Productus fournieri Demanet, 1923 [Scutepustula fournieri (Demanet, 1923)]; Maredsous, Waulsort Formation (Tournaisian, Ivorian). H-N. RBINS a11787, incomplete articulated specimen in ventral, lateral, posterior, anterior partial dorsal (a part is enclosed in matrix), and lateral oblique (showing the partial dorsal external mould) views, and detail of ornamentation (SEM). O-R. RBINS a11786, ventral valve in plan, lateral, posterior and anterior views. S. RBINS a11788, fragment of ventral valve in plan view. Scale bars: 1 mm (A-B), 10 mm (C-F, G-M, O-S), $2 \mathrm{~mm}(\mathrm{~N})$.

generic viewpoint, the costate ornamentation with few intercalations and the presence of well-developed ears may suggest an assignment to Plicochonetes Paeckelmann, 1930.

Current name. 'Chonetes' parvus Ch. Fraipont, 1908, non Shumard, 1855.

\subsubsection{Order Productida/Suborder Productidina}

Productus corrugatus var. contortus Demanet, 1923

(Fig. 9C-G)

1923 Productus corrugatus McCoy var. contortus Demanet, 
p. $92,94,152-153$, pl. 7, fig. 37, tables A-B.

Type material. The incomplete ventral valve (RBINS a11777) illustrated by Demanet (1923, pl. 7, fig. 37) is hereby designated as the lectotype (Fig. 9C-G).

Type locality and horizon. Maredsous (lime kiln quarry), Waulsort Formation (Tournaisian, Ivorian) (Figs 1-2).

Description. See Demanet (1923).

Remarks. According to Demanet (1923), the main external feature of his variety is the sinuous ornamentation that occurs per place as if the shell was broken and the pieces oriented obliquely to the general direction of the shell growth. This author considered this character as sufficient for allowing discrimination from Producta corrugata M`Coy, 1844, a species that Ferguson (1971, p. 554) thought to belong in his new genus Linoprotonia. The almost complete ventral valve registered NMING:F7186 (M`Coy, 1844, pl. 20, fig. 13 (reversed); Fig. 10A-C), from the Lower Carboniferous of Kiltullagh, Castlereagh, Co. Roscommon (Ireland), was considered as the type of the species by Delépine (1928, p. 26). According to the Article 74.6 of the Code, this citation as 'type de McCoy' acts as lectotype designation (it is impossible to be certain that it corresponds to the holotype by monotypy). The lectotype of M'Coy's species was figured by Delépine (1928, pl. 6, figs 6767bis) and Legrand-Blain (2009, pl. 2, fig. 12), but its generic assignment remains uncertain as important characters such as the presence of spines near the hinge cannot be ascertained. The poor state of preservation of the lectotype of Demanet's (1923) variety precludes a valuable comparison with the species corrugata. Of course, its particular ornament is most probably the result of problems encountered during the growth, but it does not display the strong rugae observed in the latter species. Demanet's species is temporarily promoted to specific rank pending the revision of the West European Linoprotonia species, including the species discussed by Ferguson (1971) and Mottequin (2010), but it must be noted that the species contorta differs from the type species of Linoprotonia in shell shape (illversus well-developed ears, location of the maximum width). Therefore, Demanet's species is doubtfully assigned to Linoprotonia. It was reported in the Molignée Formation (Viséan, Moliniacian) by Demanet (1923), but not mentioned in Delépine (1928), as well as in the Tournaisian of Tournai.

Current name. Linoprotonia? contorta (Demanet, 1923).

Productus dissimilis de Koninck, 1847

1847 Productus dissimilis de Koninck, p. 255-256, pl. 16, fig. 5a-c.

Type material. The single specimen illustrated by de Koninck (1847) has not been traced and may be considered as lost as it is not included in de Koninck's collection stored at the Muséum national d'Histoire naturelle, Paris (Gatinaud, 1946; Pacaud, 2015).

Type locality and horizon. According to de Koninck (1847), this species comes from the 'calcaire dévonien des environs de Chimay. Il y est très-rare', but its accurate age remains unknown as the Devonian limestones from the Chimay area are Eifelian to Frasnian in age (Marion \& Barchy, 1999).

Description. See de Koninck (1847).

Remarks. Productus dissimilis de Koninck, 1847 (not Productus dissimilis Hall, 1858 from the Upper Devonian of Iowa; see discussion in Muir-Wood \& Cooper, 1960) should be added to Mottequin's (2019) catalogue of Devonian species described in Belgium before 1950. This species is still incompletely known and was only cited occasionally in the Belgian and French literature. Mourlon $(1876,1881)$, followed by Gosselet (1888), doubtfully reported it from the Upper Famennian ('assises de Montfort et d'Evieux') of southern Belgium contrary to Maillieux (1933, 1941), who cited Productus (Avonia) dissimilis and Pustula dissimilis as occurring in the lower Famennian of this area, but specimens identified as such have not been traced in the RBINS collections. The species was reported from the Eifelian of Germany by Spriestersbach (1942) as Productella dissimilis, and assigned doubtfully to the genus Helaspis Imbrie, 1959 by May (1984, 2003). Nonetheless, it is currently impossible to discuss validly the generic assignment of this taxon further.

Current name. 'Productus' dissimilis de Koninck, 1847.

Productus fournieri Demanet, 1923

(Fig. 9H-S)

1923 Productus fournieri Demanet, p. 92, 94, 158-159, pl. 7, figs 46-48, tables A-B.

Type material. The articulated specimen RBINS a11787 (Demanet, 1923, pl. 7, fig. 47) is hereby designated as the lectotype (Fig. 9H-N); the ventral valves RBINS a11786 (Fig. 9O-R) and a11788 (Fig. 9S) (Demanet, 1923, pl. 7, figs 46, 48) are paralectotypes.

Type locality and horizon. Maredsous (lime kiln quarry), Waulsort Formation (Tournaisian, Ivorian) (Figs 1-2).

Description. See Demanet (1923).

Remarks. Sarytcheva (in Sarytcheva et al., 1963) rightly included the species fournieri in her new genus Scutepustula, whose type species is from the Tournaisian of South Urals. Carter (1999) challenged this generic assignment, but reexamination of the Belgian species confirms the development of closely spaced rugae bearing well-differentiated bands of elongate spine bases (Fig. 9N). It is obvious that further specimens are needed to validly compare the species Scutepustula fournieri from those listed by Sarytcheva (in Sarytcheva et al., 1963) and Carter (1999).

Current name. Scutepustula fournieri (Demanet, 1923).

\section{Productus maretiolensis Demanet, 1923}

(Fig. 11A-D)

1923 Productus maretiolensis Demanet, p. 94, 145-146, pl. 7, fig. 45, tables A-B.

Type material. The distorted ventral valve RBINS a11785 (Demanet, 1923, pl. 7, fig. 45) is hereby designated as the lectotype (Fig. 11A-D).

Type locality and horizon. Maredsous (lime kiln quarry), Waulsort Formation (Tournaisian, Ivorian) (Figs 1-2).

Description. See Demanet (1923).

Remarks. The large size, the shape and the ornamentation (few rugae and spines on visceral disk) suggest an assignment to Tolmatchoffia Fredericks, 1933 rather than to Dictyoclostus Muir-Wood, 1930. The lectotype displays two circular drill holes perpendicular to shell surface in the umbonal area (Fig. 11B-C) similar to those previously reported in Mississippian brachiopods from the Namur-Dinant Basin (Mottequin \& Sevastopulo, 2009; Mottequin \& Simon, 2017a, 2017b).

Current name. Tolmatchoffia maretiolensis (Demanet, 1923).

\section{Productus murchisonianus de Koninck, 1847}

1847 Productus murchisonianus de Koninck, p. 245-249, pl. 16, fig. 3a-b (?), c, not fig. 3d-f. 


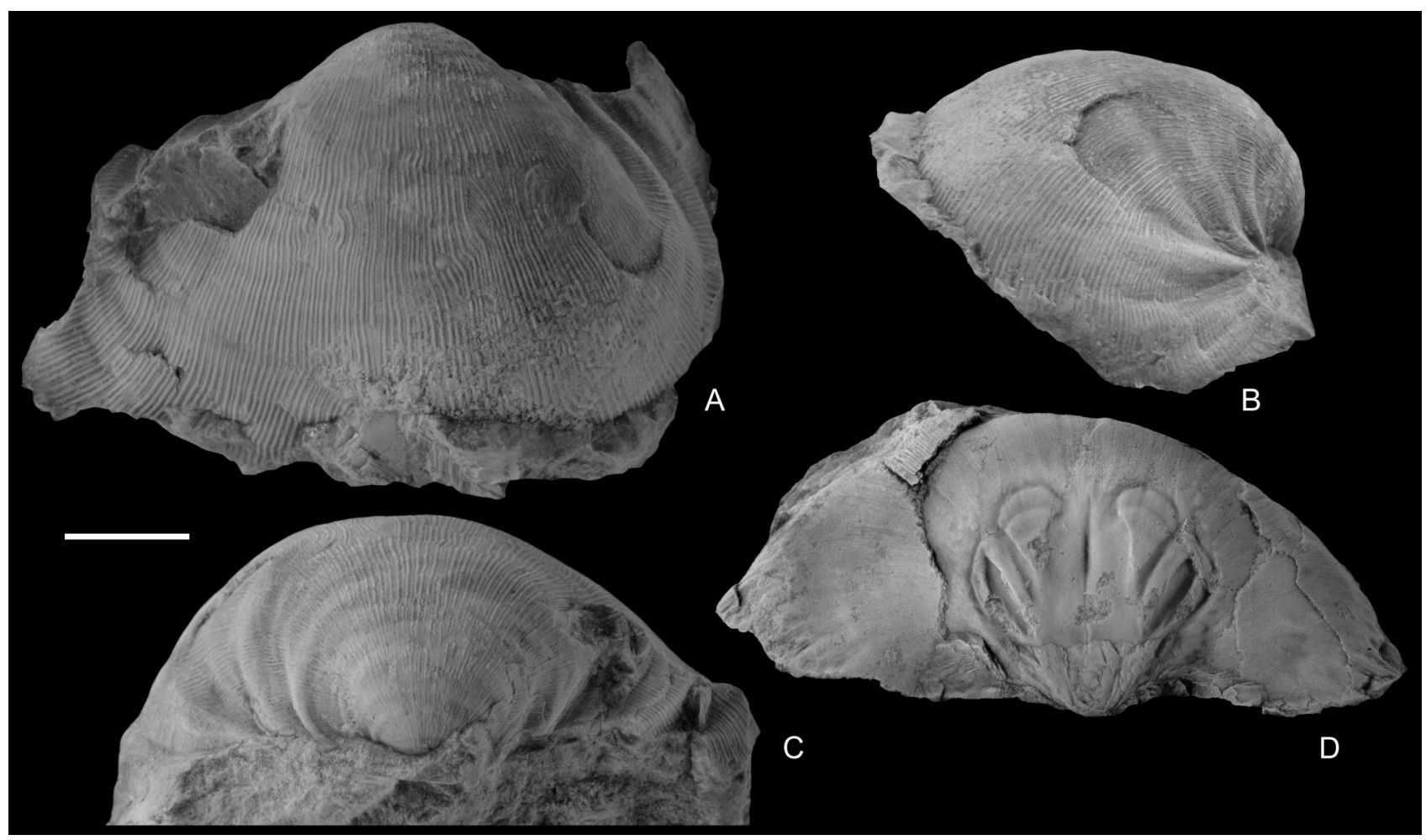

Figure 10. A-C. Producta corrugata M`Coy, 1844; NMING:F7186 (lectotype), almost complete ventral valve in plan, lateral and posterior views; Kiltullagh, Castlereagh, Co. Roscommon (Ireland), Lower Carboniferous. D. Orthis latissima M`Coy, 1844 [Schizophoria (S.) latissima (M`Coy, 1844), probably a junior synonym of $S$. (S.) resupinata resupinata (Martin, 1809)], NMING:F7449 (lectotype), incomplete and crushed dorsal internal mould with some shelly remains; St. John's Point, Dunkineely, Co. Donegal (Ireland), probably Arundian. Scale bar: 10 mm for all.

Type material. De Koninck (1847) erected the species Productus murchisonianus based on material from Tasmania, Belgium, Germany, and France (see also de Koninck, 1877). According to Gatinaud (1946) and Pacaud (2015), only one of the Australian specimens (MNHN.F.R06377) illustrated by de Koninck (1847, pl. 16, fig. 3c) has been recovered from the collections of the Muséum national d'Histoire naturelle (Paris), but other unillustrated specimens from Western Europe are also available in this institution: Belgium (Chaudfontaine (MNHN.F.R50559; Famennian?), Chimay (MNHN.F.R50557; Frasnian?, it seems to be related to Caucasiproductus? sp. indet. sensu Mottequin, 2008b) and Germany (Gerolstein (MNHN.F.R50556), Paffrath (MNHN.F.R50558)). It is obvious that de Koninck's (1847) species encompasses several taxa of different ages and should be restricted to the single illustrated specimen still available (MNHN.F.R06377; an articulated internal mould), which is hereby designated as the lectotype following the Recommendation 74B of the Code (illustrations are available via the website of the Muséum national d'Histoire naturelle: https://science.mnhn.fr/taxon/species/productus/ murchisonianus).

Type locality and horizon. The lectotype is devoid of detailed information related to its provenance and age. De Koninck (1847) simply indicated that it comes from the Devonian sandstone of Van Diemen's Land (the former name of Tasmania). Etheridge (1878) and Johnston (1888) indicated a Carboniferous age and, according to the latter author, it is from the Carboniferous Lower Marine Beds. Johnston (1887) also listed the species in his list of Upper Palaeozoic fossils from Tasmania. Nevertheless, this species could be younger (Permian) (see below).

Description. See de Koninck (1847).

Remarks. The lectotype displays strong similarities with representatives of the Permian strophalosiid genus Wyndhamia
Booker, 1929 (e.g., Wyndhamia jukesi (Etheridge, 1880); see Maxwell, 1954, and Clarke, 1969), but more specimens are required to reach a more confident generic identification. Moreover, Productus murchisonianus could be considered as a nomen oblitum.

Current name. 'Productus' murchisonianus de Koninck, 1847.

Productus plicatiliformis Demanet, 1923

(Fig. 11E-H)

1923 Productus plicatiliformis Demanet, p. 94, 161, pl. 8, fig. 52, tables A-B.

Type material. The incomplete ventral valve (RBINS a11792) illustrated by Demanet (1923) is hereby designated as the lectotype (Fig. 11E-H).

Type locality and horizon. Maredsous (lime kiln quarry), Waulsort Formation (Tournaisian, Ivorian) (Figs 1-2).

Description. See Demanet (1923).

Remarks. The lectotype displays strong, irregular rugae in the umbonal region and on the venter, and some elongate spine bases in these regions; costae and growth lines are developed on the flanks and on the trail. There is a kind of discontinuous (poor preservation?) low, median costa arising in the umbonal area. At first sight, based on the strong rugae and shape, this specimen could remind externally juveniles of Levitusia humerosa (Sowerby, 1822 in 1821-1822) (see Brunton, 1979), which is common in the Avins Member (e.g., Demanet, 1958; Brunton, 1979; Hance et al., 2006b), but the development of ribbing in the anterior part of the shell, is not observed in the latter species. From the ornamentation viewpoint, the species plicatiliformis is close to the representatives of the genus Seminucella Carter, 1987, but is considerably larger and its flanks are not subparallel. It seems more advisable to 


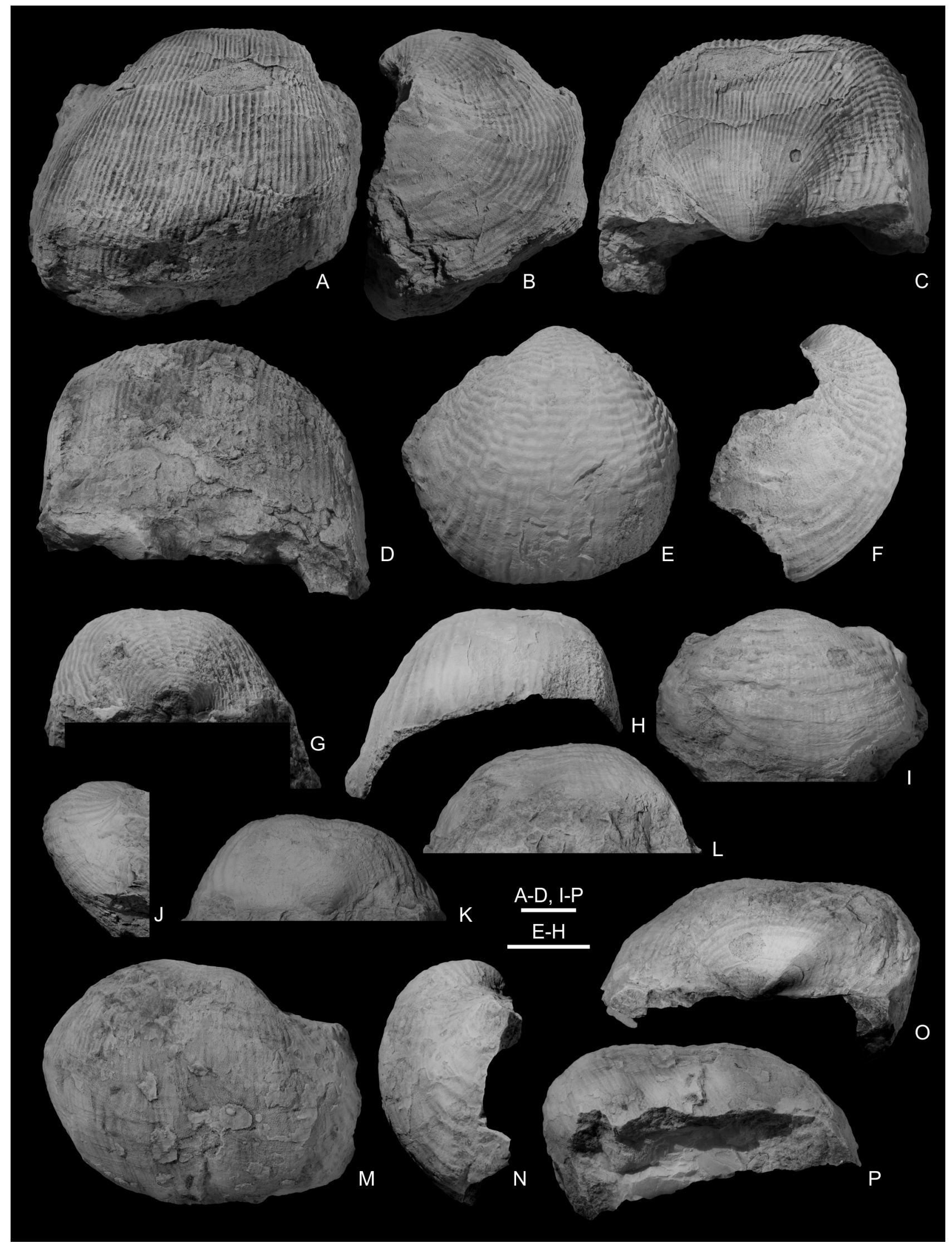

Figure 11. Productidines from Maredsous, Waulsort Formation (Tournaisian, Ivorian). A-D. Productus maretiolensis Demanet, 1923 [Tolmatchoffia maretiolensis (Demanet, 1923)], RBINS a11785 (lectotype), distorted ventral valve in plan, lateral, posterior and anterior views. E-H. Productus plicatiliformis Demanet, 1923 [Kadraliproductus? plicatiliformis (Demanet, 1923)], RBINS a11792 (lectotype), incomplete ventral valve in plan, lateral, posterior and anterior views. I-P. Productus saleei Demanet, 1923 [Dictyoclostus? saleei (Demanet, 1923)]. I-L. RBINS a11783 (paralectotype), distorted ventral valve in plan, lateral, posterior and anterior views. M-P. RBINS a11784 (lectotype), distorted and incomplete ventral valve in plan, lateral, posterior and anterior views. Scale bars: $10 \mathrm{~mm}$ for all. 
temporarily assign this species to Kadraliproductus Galitskaya 1977 as it displays the same type of ornamentation, but less coarse, than that of $K$. kadralensis (Gladtchenko, 1955) from the upper Tournaisian of Kirghizstan, even if the deficient preservation cannot permit to know accurately the longitudinal profile of the lectotype as Kadraliproductus is characterized by a strongly inflated, often geniculate ventral valve.

Current name. Kadraliproductus? plicatiliformis (Demanet, 1923).

\section{Productus saleei Demanet, 1923}

(Fig. 11I-P)

1923 Productus Saleei Demanet, p. 94, 157-158, pl. 7, figs 43-44, tables A-B.

Type material. The distorted ventral valve (an internal mould with shelly remains; RBINS a11784) illustrated by Demanet (1923, pl. 7, fig. 44) is hereby designated as the lectotype (Fig. 11M-P); the deformed ventral valve (RBINS a11783; Demanet, 1923, pl. 7, fig. 43) is a paralectotype (Fig. 11I-L).

Type locality and horizon. Maredsous (lime kiln quarry), Waulsort Formation (Tournaisian, Ivorian) (Figs 1-2).

Description. See Demanet (1923).

Remarks. Both specimens available at hand are inadequately preserved. Their shell is finely and entirely costate and strongly rugate in the posterior part. Nalivkin (1979) assigned the species saleei to the genus Fluctuaria Muir-Wood \& Cooper, 1960, but the Waulsortian material has nothing in common (e.g., absence of prominent rugae, outline not elongated) with its type species, i.e. F. undata (Defrance, 1826) from the Viséan (Warnantian) of Visé. The large size and the shape of the ventral valve (with development of sulcus) and the ornamentation suggest a provisional assignment to Dictyoclostus Muir-Wood, 1928.

Current name. Dictyoclostus? saleei (Demanet, 1923).

Productus semireticulatus var. minima Demanet, 1923 (Fig. 12A-R)

1923 Productus semireticulatus var. minima Demanet, p. 70, 144-145, pl. 6, fig. 32a-c, tables A-B.

Type material. Among the three syntypes available, of which two were previously illustrated, the specimen RBINS a11772 (Demanet, 1923, pl. 6, fig. 32b-c) is hereby designated as the lectotype (Fig. 12G-L). The specimens RBINS a11771A (Demanet, 1923, pl. 6, fig. 32a; Fig. 12A-F) and RBINS a11771B (Fig. 12M-R) are paralectotypes.

Type locality and horizon. Sosoye, Waulsort Formation or Longpré Formation (Avins Member) (Tournaisian, Ivorian) (Figs 1-2).

Description. See Demanet (1923).

Remarks. According to Muir-Wood (1928), Demanet's variety probably belongs to her longispinus group. Nevertheless, the type material does not reveal the presence of six symmetrically arranged spines as observed in representatives of the genus Eomarginifera Muir-Wood, 1930, and more particularly in its type species E. longispina (Sowerby, 1814 in 1812-1815). To our knowledge, it seems that Nalivkin (1948) was the first to promote this variety to a specific status; it was later assigned to the genus Tomiproductus Sarytcheva in Sarytcheva et al., 1963 by Nalivkin \& Fotieva (1973) and Nalivkin (1979) on the basis of Uralian material identified as such (e.g., Kucheva, 2019). Nevertheless, until now, the generic affinities of Demanet's species remain unclear due to the absence of data related to its internal morphology. Externally, the less inflated ventral umbo, the less convex and reticulate disk and evident concentric rugae prevent an assignment to Tomiproductus, but these features make it closer to Marginatia Muir-Wood \& Cooper, 1960.

Current name. Marginatia? minima (Demanet, 1923).

\section{Productus soreili Demanet 1923}

(Fig. 12S-V)

1923 Productus Soreili Demanet, p. 94, 136-137, pl. 5, fig. 20a-b, tables A-B.

Type material. The poorly preserved ventral valve (RBINS a11759) illustrated by Demanet (1923, pl. 5, fig. 20a-b) is hereby designated as the lectotype (Fig. 12S-V) because he reported that the species is quite common in the type locality.

Type locality and horizon. Maredsous (lime kiln quarry), Waulsort Formation (Tournaisian, Ivorian) (Figs 1-2).

Description. See Demanet (1923).

Remarks. The species was reported, but not illustrated, from Waulsortian facies of north-west County Limerick by ShephardThorn (1963), who assigned it to the genus Pustula Thomas, 1914. The presence of numerous low, irregular rugae and the few spines may suggest such an assignment.

Current name. Pustula? soreili (Demanet, 1923).

\subsubsection{Order Orthotetida}

Orthotetes crenistria var. maxima Demanet, 1923

(Fig. 13A-C)

1923 Orthothetes [sic] crenistria var. maxima Demanet, p. 94, 126, pl. 5, fig. 10, tables A-B.

Type material. The dorsal valve (RBINS a 11749, Fig. 13AC) illustrated by Demanet (1923, pl. 5, fig. 10) is hereby designated as the holotype (by monotypy) as he clearly stated that only one specimen was available for study.

Type locality and horizon. Maredsous (lime kiln quarry), Waulsort Formation (Tournaisian, Ivorian) (Figs 1-2).

Description. See Demanet (1923).

Remarks. Demanet (1934) placed Orthotetes crenistria maxima in the synonymy of the poorly known species Orthotetes fascifera Tornquist, 1895 from the Viséan of the Rossberg Massif (France, southern Vosges), which was transferred to Schuchertella Girty, 1904 by Paeckelmann (1930) and himself. However, according to Tornquist (1895), the shell of his new species is very flat, which precludes such synonymy. Currently, based on the features observable on the holotype, Demanet's (1923) species is assigned to Schellwienella Thomas, 1910 but readily cannot be considered as a subspecies of $S$. crenistria (Phillips, 1836) due to its more inflated dorsal valve. Furthermore, this Schellwienella displays a more transverse outline than that of $S$. radialiformis Demanet, 1934 from the Tournaisian of the Tournai area (see Mottequin \& Simon, 2017b).

Current name. Schellwienella maxima (Demanet, 1923).

\subsubsection{Order Orthida}

Dumont (1832), Davreux (1833) and de Koninck (1843, in 18421844) were the first to report the presence of schizophoriides in the Mississippian of southern Belgium. Six varieties of Schizophoria (Schizophoria) resupinata (Martin, 1809) were described by Demanet $(1923,1934)$ on the basis of specimens from the Tournaisian and the Viséan of the Namur-Dinant Basin, namely the varieties (subspecies according to the Code, 


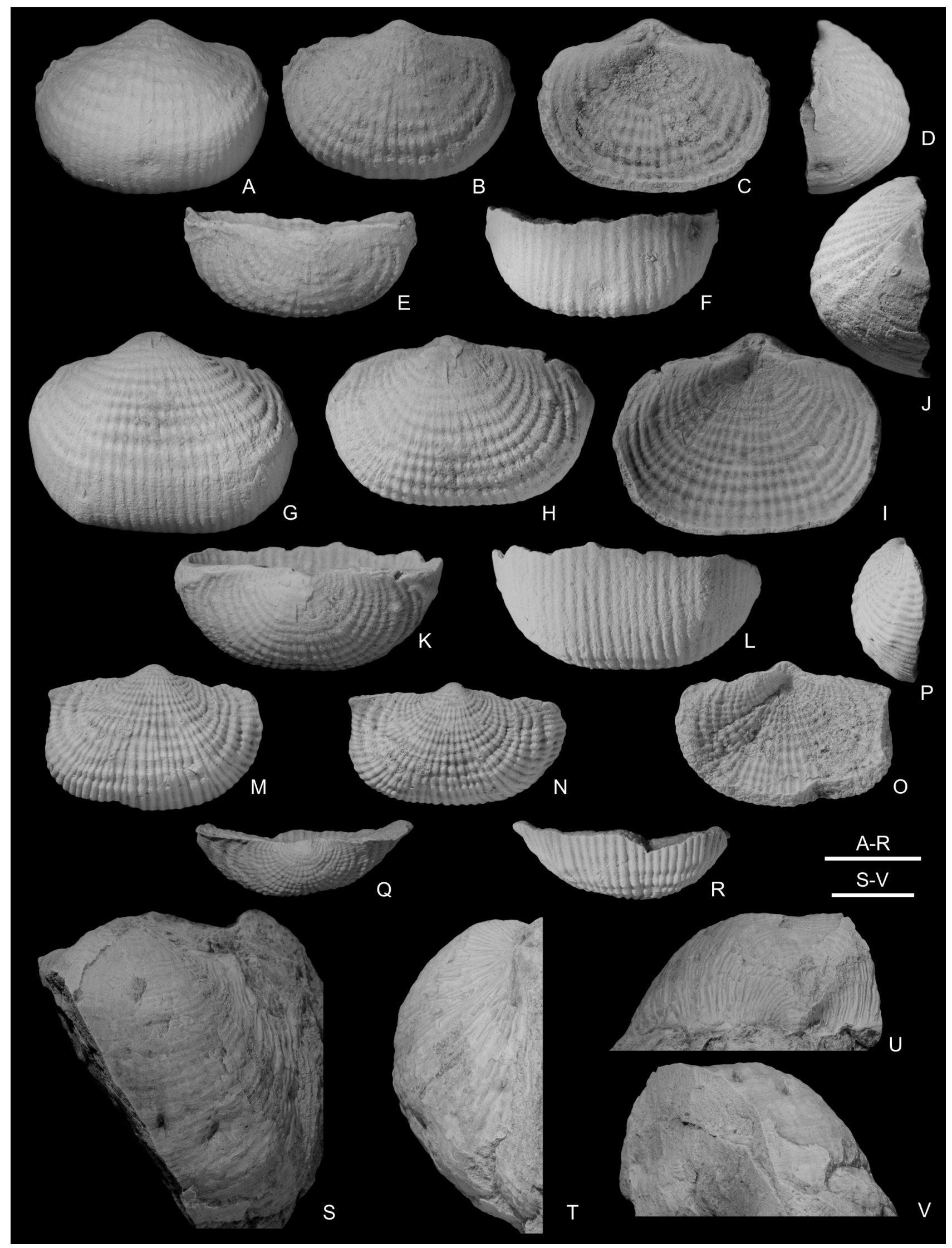

Figure 12. A-R. Productus semireticulatus var. minima Demanet, 1923 [Marginatia? minima (Demanet, 1923)]; Sosoye, Waulsort Formation or Longpré Formation (Avins Member) (Tournaisian, Ivorian). A-F. RBINS a11771A (paralectotype), articulated specimen in ventral, posteroventral, dorsal, lateral, posterior and anterior views. G-L. RBINS a11772 (lectotype), articulated specimen in ventral, posteroventral, dorsal, lateral, posterior and anterior views. M-R. RBINS a11771B (paralectotype), articulated specimen in ventral, posteroventral, dorsal, lateral, posterior and anterior views. S-V. Productus soreili Demanet, 1923 [Pustula? soreili (Demanet, 1923)], RBINS a11759 (lectotype), incomplete ventral valve in plan, lateral, posterior and anterior views; Maredsous, Waulsort Formation (Tournaisian, Ivorian). Scale bars: $5 \mathrm{~mm}$ (A-R), $10 \mathrm{~mm}$ (S-V). 


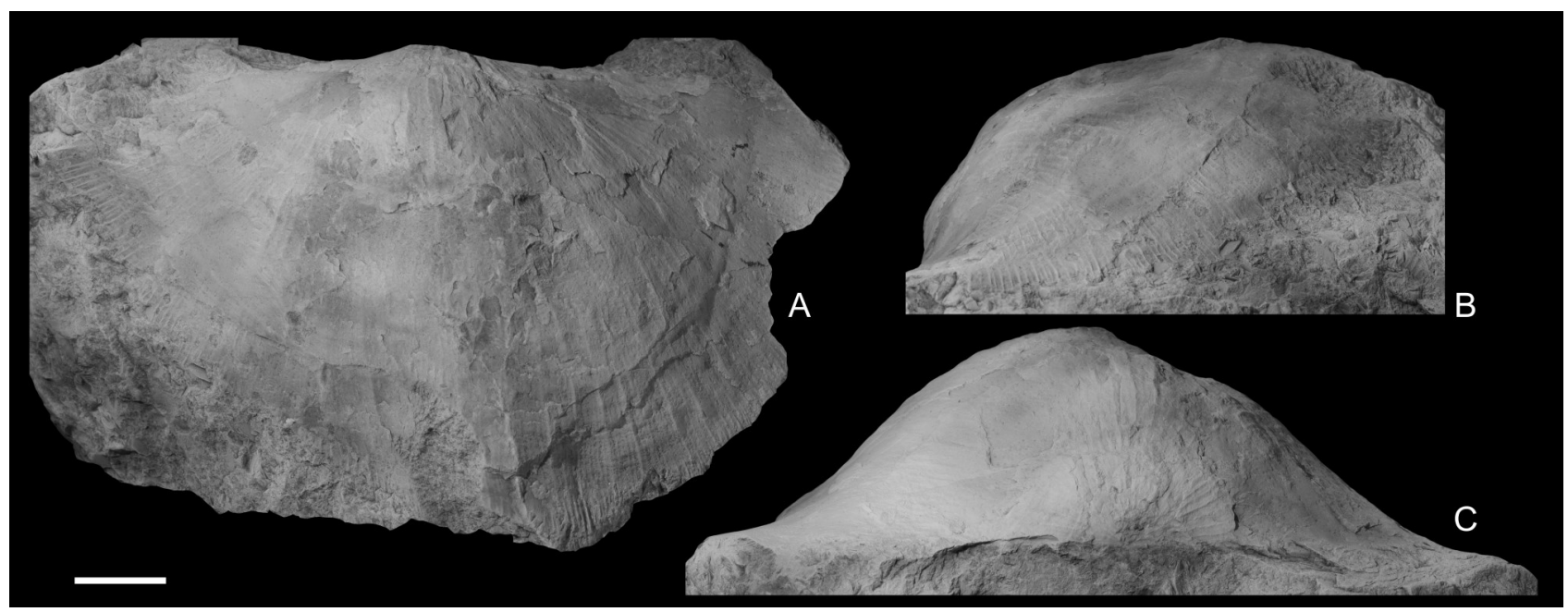

Figure 13. Orthotetes crenistria var. maxima Demanet, 1923 [Schellwienella maxima (Demanet, 1923)]; Maredsous, Waulsort Formation (Tournaisian, Ivorian). A-C. RBINS a1 1749 (holotype), ventral valve (RBINS a11749) in plan, lateral and posterior views. Scale bar: $10 \mathrm{~mm}$ for all.

see preliminary remarks above) dorsosinuata, gigantea, lata, palliata, pinguis, and rotundata (Figs 2, 14). They were subsequently discussed notably by Bond (1941), Parkinson (1954), Pocock (1965, 1968), Brunton (1968), Lazarev (1976), Martínez Chacón (1979), and Żakowa (1989). Most of these varieties have been synonymized with Schizophoria (S.) resupinata (Martin, 1809) or other species, but some of them were considered as distinct subspecies although there is no consensus according to the literature data (see above). The complete investigation of the different Schizophoria lineages present in the Belgian Carboniferous succession is well beyond the scope of this paper as it requires, wherever it is possible, new field collections in order to detail the relationships between the shape of the shell and the environmental conditions (see also Parkinson, 1954, and Bassett \& Bryant, 2006). As a first step in this direction, the illustrated type specimens figured by Demanet $(1923,1934)$ are fully illustrated here for the first time; to our knowledge, only one original specimen of $S$. (S.) resupinata dorsosinuata Demanet, 1934 was figured recently by Mottequin \& Weyer (2019).

Besides Demanet's subspecies enumerated above, at least five species were recognized in the Mississippian succession of southern Belgium: Schizophoria (S.) connivens (Phillips, 1836), S. (S.) aff. hudsoni George, 1932 (George's species was considered as distinct of $S$. connivens by Pocock, 1965, but as a synonym of Phillips' species by Pocock, 1968), S. (S.) resupinata resupinata, S. (Pocockia) gibbera (Portlock, 1843), and S. (Paraschizophoria) woodi Bond, 1941 (see Demanet, 1923, 1934, 1941; Bond, 1941; Pocock 1965, 1968). In Belgium, the youngest occurrence of Schizophoria, which cannot be checked currently, could be Demanet's (1943) doubtful report of the genus within the Ransart Member of the Châtelet Formation (Bashkirian, Westphalian A according to the traditional subdivision). It is also necessary to cite here the species Orthis Koninckii (recte konincki) introduced by d'Orbigny (1849) for Devonian and Carboniferous schizoporiids illustrated by de Koninck (1843 in 1842-1844). It was briefly discussed by Pocock (1965), but it remains inadequately known.

The thorough revision of the Tournaisian and Viséan schizophoriids from Western Europe is long overdue and it should be a long-term work involving the revision of numerous types. Note that the neotype of the species resupinata was selected by George \& Ponsford (1938, p. 228) and figured by Bond (1941, pl. 21, figs A-C), Parkinson (1954, fig. 1), Pocock (1965, pl. 3 [Carboniferous], fig. 7a-e), Wright (1965, fig. 210,5a-5b), and Brunton (1968, pl. 2, figs 1-3).

Schizophoria resupinata var. dorsosinuata Demanet, 1934 (Figs 14A, 15A-J)

1934 Schizophoria resupinata var. dorsosinuata Demanet, p. 53-54, 105, pl. 3, figs 14-15.

Type material. Both specimens illustrated by Demanet (1934) are hereby designated as lectotype (RBINS a5869, Figs 14A, 15A-E; Demanet, 1934, pl. 3, figs 14, 14a-14b; Mottequin \& Weyer, 2019, fig. 18a-e) and paralectotype (RBINS a5870, Fig. 15F-J; Demanet, 1934, pl. 3, fig. 15, 15a-15b), respectively.

Type locality and horizon. Tournai area, 'Assise de Celles' (Demanet, 1934) (Figs 1-2). Mortelmans (1969) recorded the species in the Tournai Formation (Pont-à-Rieu Member of Ivorian age).

Description. See Demanet (1934), Brunton (1968), and Pocock (1968).

Remarks. According to Pocock (1968), Demanet's varieties (except palliata) merely represent extreme individual variations. Nevertheless, such a statement should be reassessed in the future, based on the reinvestigation of the types of the different species and subspecies.

Current name. Schizophoria (Schizophoria) resupinata dorsosinuata Demanet, 1934.

Schizophoria resupinata var. gigantea Demanet, 1934

(Figs 14B, 15K-Q)

1934 Schizophoria resupinata var. gigantea Demanet, p. 60, 105 , pl. 4, figs 12-13.

Type material. Both specimens illustrated by Demanet (1934) are hereby designated as lectotype (RBINS a5888, Figs 14B, 15K-O; Demanet, 1934, pl. 4, fig. 12) and paralectotype (RBINS a5889, Fig. 15P-Q; Demanet, 1934, pl. 4, fig. 13), respectively.

Type locality and horizon. Visé, Visé Formation (Viséan, Warnantian) (Figs 1-2). Note that four main facies composed of pale to grey limestones are distinguished among this lithostratigraphic unit (see Poty et al., 2002 for more details). Most of the macrofossils that contributed to the fame of the Viséan fauna from Visé (Mottequin \& Poty, in press) were collected within buildups composed of massive algal and 


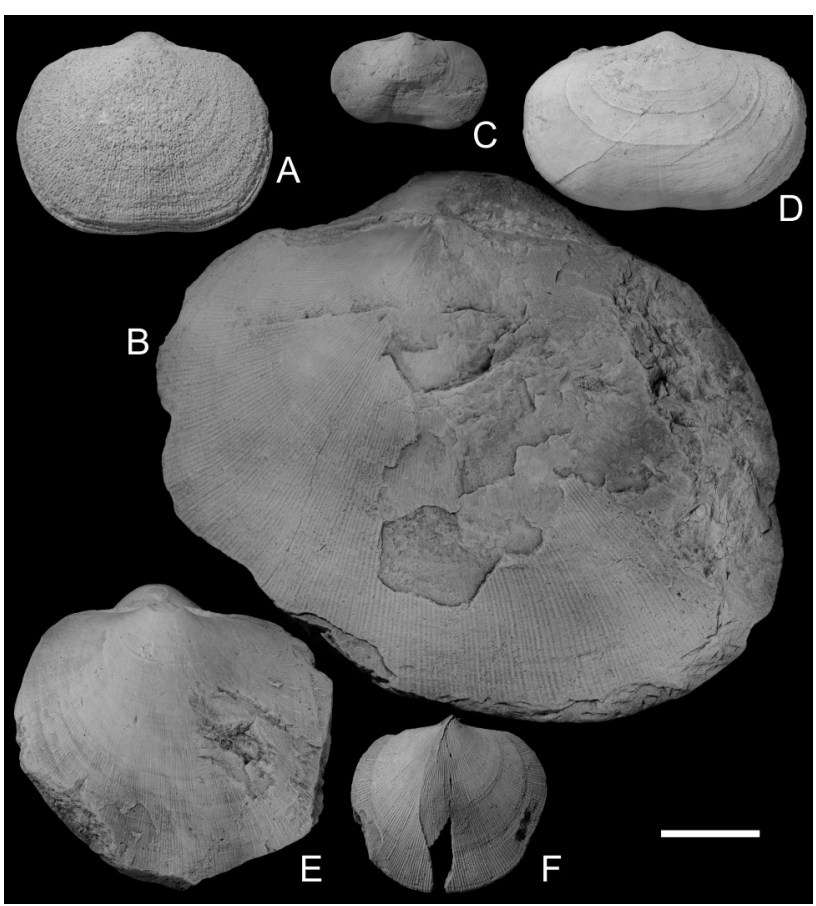

Figure 14. Size comparison of the lectotypes of Demanet's (1923, 1934) varieties of Schizophoria (Schizophoria) resupinata (Martin, 1809); all are presented in ventral view. A. Schizophoria resupinata var. dorsosinuata Demanet, 1934 [Schizophoria (Schizophoria) resupinata dorsosinuata Demanet, 1934], RBINS a5869 (Fig. 15A-E); Tournai area, 'Assise de Celles' (Tournaisian). B. Schizophoria resupinata var. gigantea Demanet, 1934 [Schizophoria (Schizophoria) resupinata gigantea Demanet, 1934], RBINS a5888 (Fig. 15K-O); Visé, Visé Formation (Viséan, Warnantian). C. Schizophoria resupinata var. lata Demanet, 1923 [Schizophoria (Schizophoria) resupinata lata Demanet, 1923], RBINS a11743 (Fig. 15R-V); Sosoye, Waulsort Formation or Longpré Formation (Avins Member) (Tournaisian, Ivorian). D. Schizophoria resupinata var. palliata Demanet, 1934 [Schizophoria (Pocockia) linguata (Quenstedt, 1871 in 1868-1871)], RBINS a5883 (Fig. 16A-D); Dréhance, Waulsort Formation (Tournaisian, Ivorian). E. Schizophoria resupinata var. pinguis Demanet, 1934 [Schizophoria (Schizophoria) resupinata pinguis Demanet, 1934], RBINS a5885 (Fig. 17F-J); Visé, Visé Formation (Viséan, Warnantian). F. Schizophoria resupinata var. rotundata Demanet, 1923 [Schizophoria (Schizophoria) resupinata rotundata Demanet, 1923], RBINS a11744 (Fig. 16I-M) Sosoye, Waulsort Formation or Longpré Formation (Avins Member) (Tournaisian, Ivorian). Scale bar: $10 \mathrm{~mm}$ for all.

bioclastic boundstones (Poty et al., 2002) belonging to the Mississippian Foraminifer Zone 14 (Poty et al., 2006). According to Aretz \& Chevalier (2007), this particular lithofacies is close to the Cracoean facies of England (Mundy, 1994).

Description. See Demanet (1934), Pocock (1968).

Remarks. As for Schizophoria resupinata var. dorsosinuata.

Current name. Schizophoria (Schizophoria) resupinata gigantea Demanet, 1934.

Schizophoria resupinata var. lata Demanet, 1923

(Figs 14C, 15R-V)

1923 Schizophoria resupinata Martin var. lata Demanet, p. 69, 122, pl. 5, fig. 4, tables A-B.

1934 Schizophoria resupinata var. lata Demanet; Demanet, p. $50-51,105$, pl. 3 , figs $6-8$.

Type material. The specimen RBINS a11743 (Figs 14C, 15R-
V) figured by Demanet (1923, pl. 5, fig. 4) is hereby designated as the lectotype.

Type locality and horizon. Sosoye, Waulsort Formation or Longpré Formation (Avins Member) (Tournaisian, Ivorian) (Figs 1-2).

Description. See Demanet $(1923,1934)$ and Pocock (1968).

Remarks. As for Schizophoria resupinata var. dorsosinuata. The lectotype of this subspecies is a young specimen that is considerably smaller than most of the specimens (RBINS a5861 -5863; not illustrated here) figured by Demanet (1934) from the Waulsort Formation (Vêves; Fig. 1). Furthermore, Demanet (1934) compared S. resupinata var. lata Demanet, 1923 with Orthis latissima $\mathrm{M}^{\circ} \mathrm{Coy}, 1844$ but he was probably not aware about the distorted character of the specimen illustrated by $\mathrm{M}^{\prime}$ Coy (1844). Orthis latissima undoubtedly belongs to Schizophoria and is probably a junior synonym of the long ranging species $S$. (S.) r. resupinata (Martin, 1809) (compare the large dorsal muscle field of the lectotype with that of Martin's species illustrated by Pocock (1968, text-fig. 14)) as mentioned by Davidson (1861). M'Coy's species has been overlooked in the studies dedicated to the Carboniferous schizophoriides from Western Europe (e.g., Bond, 1941; Pocock, 1968). For taxonomical purpose, the incomplete and crushed dorsal internal mould with some shelly remains (NMING:F7449, Fig. 10D), illustrated by $\mathrm{M}^{`} \mathrm{Coy}$ (1844, pl. 20 fig. 20 [left part]), is hereby designated as the lectotype (it is impossible to be certain that it corresponds to the holotype by monotypy). It comes from St. John's Point, Dunkineely, Co. Donegal (Ireland), and is probably of Arundian age (N.T. Monaghan, pers. com., September 2008). The shelly fragment showing the muscle scars and corresponding to M'Coy's central figure has not been traced, whereas the right is most probably an external reconstruction of the lectotype showing the fine ornament.

Current name. Schizophoria (Schizophoria) resupinata lata Demanet, 1934.

Schizophoria resupinata var. palliata Demanet, 1934 (Figs 14D, 16A-H)

1934 Schizophoria resupinata var. palliata Demanet, p. 58 59,105 , pl. 4, figs $7-8$

Type material. Contrary to Pocock's (1965) statement, both specimens illustrated by Demanet (1934, pl. 4, figs 7-8) are not lost. Bond (1941) selected the almost complete ventral valve (RBINS a5883, Figs 14D, 16A-D) illustrated by Demanet (1934, pl. 4, figs 7, 7a-7b) as the holotype. According to the Article 74.5 of the Code, the misuse of the term 'holotype' by Bond (1941) acts however as lectotype designation as this author explicitly indicated, when wrongly using the term 'holotype', that he was selecting from the specimens illustrated by Demanet (1934); the dorsal valve RBINS a5884 (Demanet, 1934, pl. 4, fig. 8) is thus a paralectotype (Fig. 16E-H).

Type locality and horizon. Dréhance (Fossé des Tchawias), Waulsort Formation (Tournaisian, Ivorian) (Figs 1-2).

Description. See Demanet (1934), Bond (1941) and Pocock (1968).

Remarks. Bond (1941) promoted Demanet's variety to species level and it was considered later as a junior synonym of Orthis linguata Quenstedt, 1871 in 1868-1871 from the 'Bergkalke von Ratingen' (Germany, Velbert Anticline; see Herbig, 2016 for an overview of the Mississippian succession in this area). This species was included by Lazarev (1976) in his new subgenus Schizophoria (Pocockia).

Current name. Schizophoria (Pocockia) linguata (Quenstedt, 1871 in 1868-1871). 


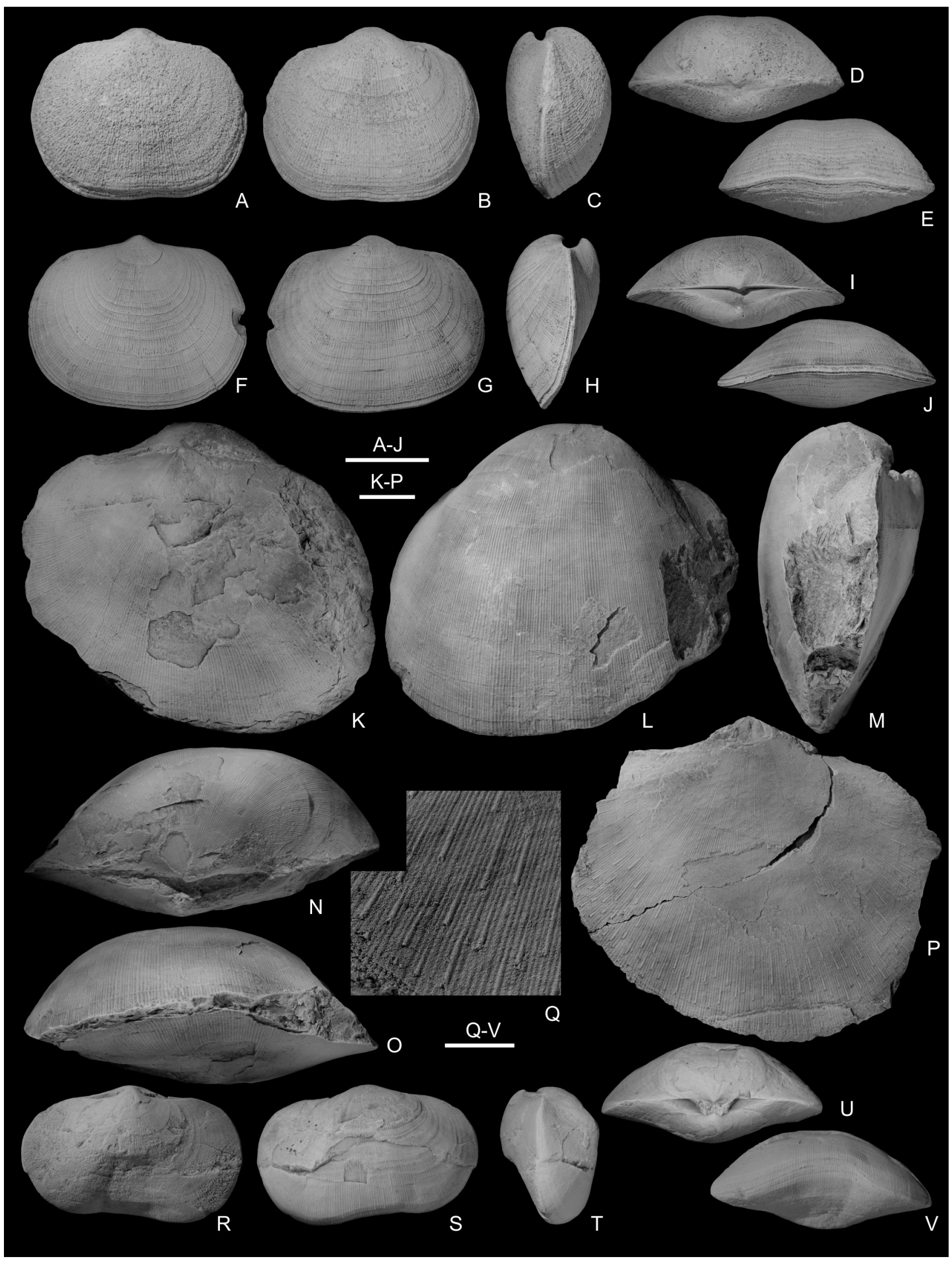

Figure 15. A-J. Schizophoria resupinata var. dorsosinuata Demanet, 1934 [Schizophoria (Schizophoria) resupinata dorsosinuata Demanet, 1934]; Tournai area, 'Assise de Celles' (Tournaisian). A-E. RBINS a5869 (lectotype), articulated specimen in ventral, dorsal, lateral, posterior and anterior views. F-J. RBINS a5870 (paralectotype), articulated specimen in ventral, dorsal, lateral, posterior and anterior views. K-P. Schizophoria resupinata var. gigantea Demanet, 1934 [Schizophoria (Schizophoria) resupinata gigantea Demanet, 1934]; Visé, Visé Formation (Viséan, Warnantian). K-O. RBINS a5888 (lectotype), distorted articulated specimen in ventral, dorsal, lateral, posterior and anterior views. P-Q. RBINS a5889 (paralectotype), ventral valve in plan view and detail of the ornamentation. R-V. Schizophoria resupinata var. lata Demanet, 1923 [Schizophoria (Schizophoria) resupinata lata Demanet, 1923], RBINS a11743 (lectotype) in ventral, dorsal, lateral, posterior and anterior views; Sosoye, Waulsort Formation or Longpré Formation (Avins Member) (Tournaisian, Ivorian). Scale bars: $10 \mathrm{~mm}$ (A-J, K-P), $5 \mathrm{~mm}(\mathrm{Q}-\mathrm{V})$. 


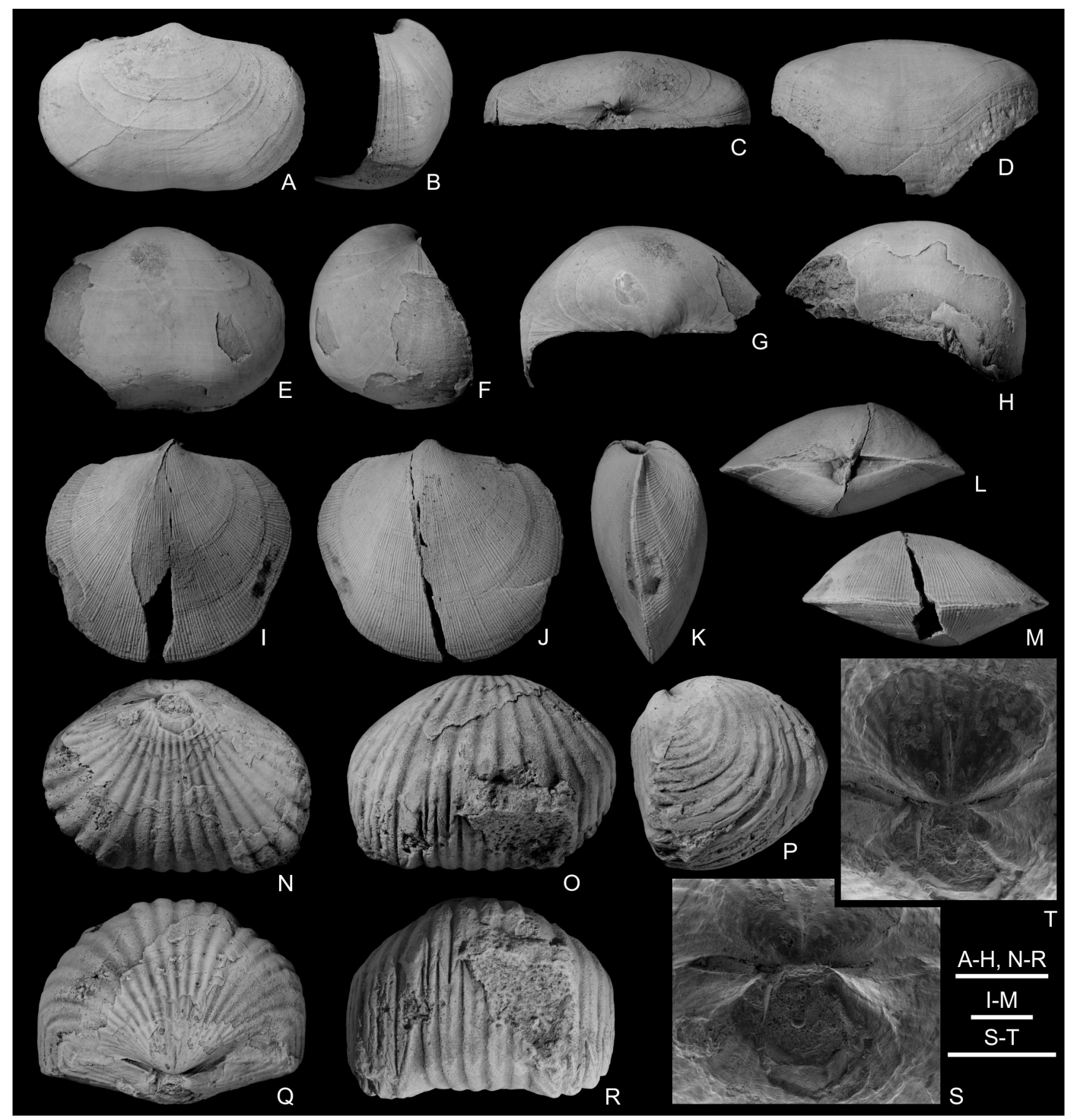

Figure 16. A-H. Schizophoria resupinata var. palliata Demanet, 1934 [Schizophoria (Pocockia) linguata (Quenstedt, 1871 in 1868-1871)]; Dréhance, Waulsort Formation (Tournaisian, Ivorian). A-D. RBINS a5883 (lectotype), almost complete valve in plan, lateral, posterior and anterior views. E-H. RBINS a5884 (paralectotype), slightly distorted dorsal valve in plan, lateral, posterior and anterior views. I-M. Schizophoria resupinata var. rotundata Demanet, 1923 [Schizophoria (Schizophoria) resupinata rotundata Demanet, 1923], RBINS a11744 (lectotype), slightly distorted articulated specimen in ventral, dorsal, lateral, posterior and anterior views; Sosoye, Waulsort Formation or Longpré Formation (Avins Member) (Tournaisian, Ivorian). N-T. Camarophoria destinezi Ch. Fraipont, 1908 [Pleuropugnoides? destinezi (Ch. Fraipont, 1908)], ULg.PA. 2020.07.13/3 (lectotype), articulated specimen in ventral, dorsal, lateral, posterior and anterior views, and detail (SEM) of the dental plates and the dorsal septum; Flavion, Waulsort Formation (Tournaisian, Ivorian). Scale bars: $10 \mathrm{~mm}$ (A-H, N-R), $5 \mathrm{~mm}$ (I-M, S-T).

Schizophoria resupinata var. pinguis Demanet, 1934 (Figs 14E, 17A-O)

1934 Schizophoria resupinata var. pinguis Demanet, p. 5960, 105, pl. 4, figs 9-11.

Type material. The specimen RBINS a5885 illustrated by Demanet (1934, pl. 4, fig. 9-9a) is hereby designated as the lectotype (Figs 14E, 17F-J). The two other specimens RBINS a5886 (Demanet, 1934, pl. 4, fig. 10) (Fig. 17A-E) and RBINS a5887 (Demanet, 1934, pl. 4, fig. 11) (Fig. 17K-O) have thus to be considered as paralectotypes.

Type locality and horizon. Visé, Visé Formation (Viséan, Warnantian) (Figs 1-2). See remark for Schizophoria resupinata var. gigantea.

Description. See Demanet (1934) and Pocock $(1965,1968)$.

Remarks. As for Schizophoria resupinata var. dorsosinuata.

Current name. Schizophoria (Schizophoria) resupinata pinguis Demanet, 1934. 


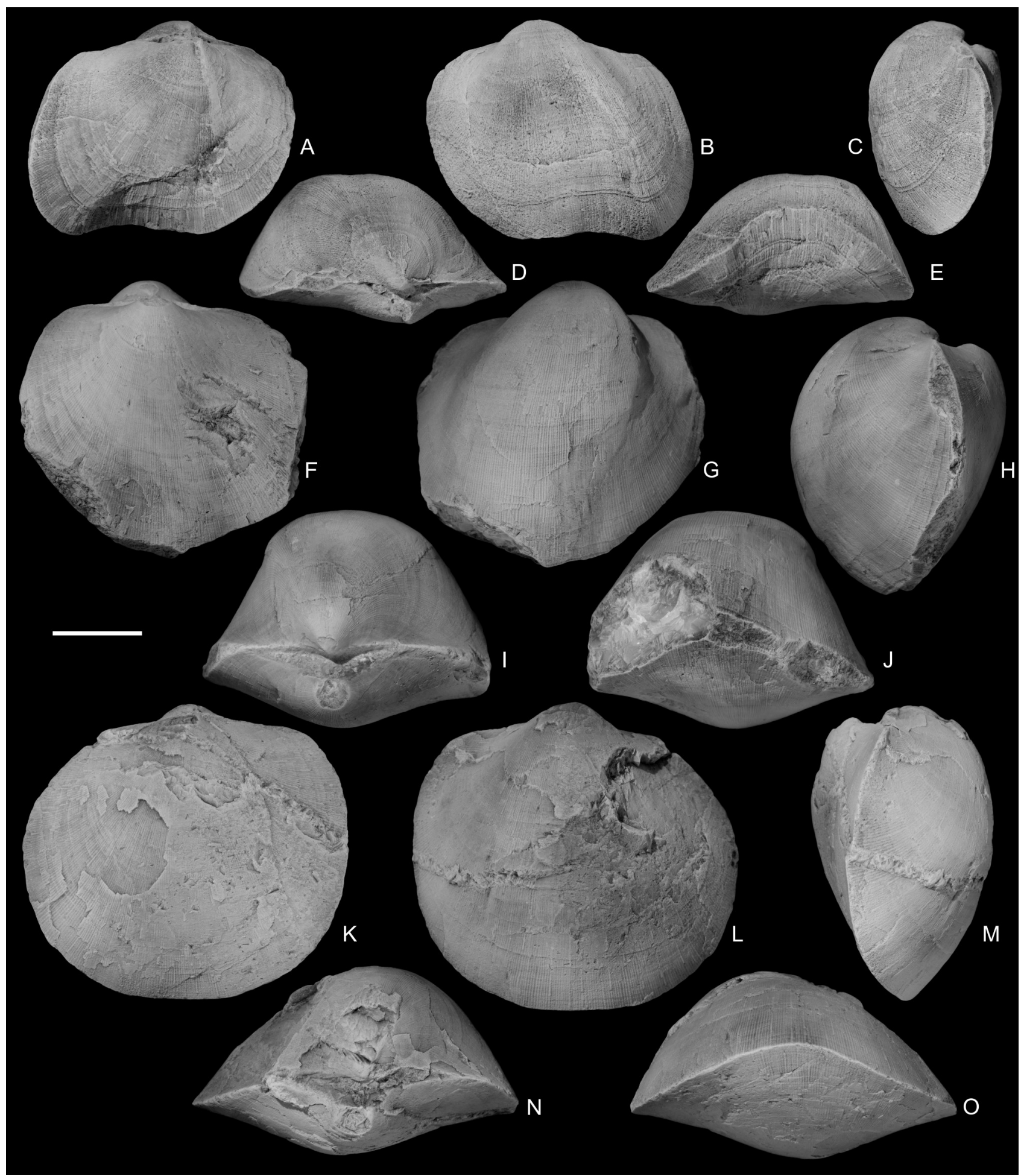

Figure 17. Schizophoria resupinata var. pinguis Demanet, 1934 [Schizophoria (Schizophoria) resupinata pinguis Demanet, 1934]; Visé, Visé Formation (Viséan, Warnantian). A-E. RBINS a5886 (paralectotype), distorted articulated specimen in ventral, dorsal, lateral, posterior and anterior views. F-J. RBINS a5885 (lectotype), distorted articulated specimen in ventral, dorsal, lateral, posterior and anterior views. K-O. RBINS a5887 (paralectotype), distorted articulated specimen in ventral, dorsal, lateral, posterior and anterior views. Scale bar: $10 \mathrm{~mm}$.

Schizophoria resupinata var. rotundata Demanet, 1923 (Figs 14F, 16I-M)

1923 Schizophoria resupinata Martin var. rotundata Demanet, p. 69, 122, pl. 5, fig. 5, tables A-B.

1934 Schizophoria resupinata var. rotundata Demanet; Demanet, p. 51-53, 105, pl. 3, figs 9-13, text-fig. 10.

Type material. The specimen RBINS a11744 figured by
Demanet (1923, pl. 5, fig. 5) is hereby designated as the lectotype (Figs 14F, 16I-M).

Type locality and horizon. Sosoye, Waulsort Formation or Longpré Formation (Avins Member) (Tournaisian, Ivorian) (Figs 1-2).

Description. See Demanet $(1923,1934)$ and Pocock (1965, 1968).

Remarks. As for Schizophoria resupinata var. dorsosinuata. Besides the lectotype, Demanet (1934, pl. 3, fig. 11) illustrated a 
dorsal valve (RBINS a5866) from the Waulsort Formation of the Dinant area (Anseremme, Fig. 1) assigned to the variety rotundata whereas the other specimens (RBINS a5864-5865, 5867-5868) identified as such by Demanet (1934, pl. 3, figs 910, 12-13, text-fig. 10) are from the Hastarian Pont d'Arcole Formation at Hastière (Fig. 1).

Current name. Schizophoria (Schizophoria) resupinata rotundata Demanet, 1923.

\subsubsection{Order Rhynchonellida}

Camarophoria destinezi Ch. Fraipont, 1908

(Fig. 16N-T)

1908 Camarophoria Destinezi Ch. Fraipont, p. M11-M12, pl. 4, fig. 3a-d.

Type material. The articulated, partly decorticated specimen (ULg.PA. 2020.07.13/3) illustrated by Ch. Fraipont (1908, pl. 4, fig. 3a-d) is hereby designated as the lectotype (Fig. 16N-T).

Type locality and horizon. Flavion; as for Chonetes parva (see above), Ch. Fraipont (1908) indicated 'Waulsortien' as the type horizon, Waulsort Formation (Tournaisian, Ivorian) (Figs 1-2).

Description. See Ch. Fraipont (1908).

Remarks. As recently indicated by Mottequin \& Simon (2017b), several costate rhynchonellide species were reported in the Waulsortian mounds by de Koninck (1887) and Demanet $(1923,1958)$, but none were recently revised. At first view, Ch. Fraipont's (1908) species differs from Rhynchonella laeta de Koninck, 1887, probably a representative of the genus Pleuropugnoides Ferguson, 1966 and possibly a junior synonym of P. pleurodon (Phillips, 1836), by its larger size, by its rounded ribs and its less developed sulcus. These two taxa were reported from the Flavion Waulsortian mound by Demanet (1958), who did not cite the species destinezi. The broken beak of the lectotype shows thin dental plates largely diverging anteriorly in the most posterior part and well-developed, concave palintropes (Fig. 16S-T); the decortication enables to observe the onset of the dorsal median septum reflected by the presence of a median furrow (Fig. 16S-T). From the generic viewpoint, a provisional assignment to Pleuropugnoides Ferguson, 1966 is the most satisfactory pending the examination of further material. 1908).

Current name. Pleuropugnoides? destinezi (Ch. Fraipont,

\subsubsection{Order Spiriferida}

Spirifer konincki var. attenuiformis Demanet, 1923 (Fig. 18A-F)

1923 Spirifer Konincki Dewalque vel Douglas [sic] var. attenuiformis Demanet, p. 94, 170-171, pl. 8, fig. 60a-b, tables A-B.

Type material. The almost complete specimen (RBINS a11800) figured by Demanet (1923, pl. 8, fig. 60a-b) is hereby designated as the lectotype (Fig. 18A-F).

Type locality and horizon. Maredsous (lime kiln quarry), Waulsort Formation (Tournaisian, Ivorian) (Figs 1-2).

Description. See Demanet (1923).

Remarks. Bublichenko (1976) and Sartenaer \& Plodowski (2002) rightly considered the single specimen illustrated by Demanet (1923) as a juvenile of Mesochorispira konincki (Dewalque, 1895). This catalogue is an opportunity to complement Sartenaer \& Plodowski's (2002) revision of $M$. konincki in figuring the internal mould of a large specimen that illustrates their description of the ventral muscle field (Fig. 18G-L).
Current name. Mesochorispira konincki (Dewalque, 1895).

Spirifer konincki var. latissimus Demanet, 1923

(Fig. 19A-E)

1923 Spirifer konincki Dewalque vel Douglas var. latissimus Demanet, p. 94, 169-170, pl.8, fig. 61, tables A-B.

Type material. The incomplete and distorted specimen (RBINS a11801) illustrated by Demanet (1923, pl. 8, fig. 61) is hereby designated as the lectotype (Fig. 19A-E).

Type locality and horizon. Maredsous (lime kiln quarry), Waulsort Formation (Tournaisian, Ivorian) (Figs 1-2).

Description. See Demanet (1923).

Remarks. As stated by Sartenaer \& Plodowski (2002), the only specimen illustrated by Demanet (1923) is distinct from Mesochorispira konincki due to its ribbing pattern and its markedly transverse outline. On the flanks, some of the inner ribs bifurcate anteriorly, but it is highly probable that they bifurcate near the beak; there is no fasciculation. Microornament consists of capillae and growth microlines (reticulate pattern) (Fig. 19E). The broken beak shows relatively thin but well-individualized dental plates (Fig. 19D). The particular outline and the ribbing pattern suggest an assignment to Grandispirifer Yang, 1959, but the development of distinct dental plates challenges such assignment. Nevertheless, until now, all the sections in specimens assigned to Yang's genus are poorly detailed and better illustrations are badly needed (Yang, 1959; Shi et al., 2016). Also, the presence of dental adminicula in Grandispirifer was discussed by different authors such as Plodowski (1970), Thomas (1971), Legrand-Blain (1986), and Carter (2006).

Current name. Grandispirifer? latissimus (Demanet, 1923).

\subsubsection{Order Terebratulida}

\section{Camarophoria pentangulata Demanet, 1923}

(Fig. 20A-F)

1923 Camarophoria pentangulata Demanet, p. 190-191, pl. 11, fig. 88a-b, tables A-B.

Type material. The articulated specimen (RBINS a11828) illustrated by Demanet (1923) is hereby designated as the lectotype (Fig. 20A-F).

Type locality and horizon. Sosoye, Waulsort Formation or Longpré Formation (Les Avins Member) (Tournaisian, Ivorian) (Figs 1-2).

Description. See Demanet (1923).

Remarks. The particular morphology (strongly ventribiconvex profile, plicosulcate anterior commissure) of this minute shell recalls that of Terebratula reflexa de Koninck, 1843 in 1842-1844 from the Viséan (Warnantian) of Visé, which is also markedly ventribiconvex and strongly unisulcate (Fig. 20GK; specimen RBINS a5402 illustrated by de Koninck, 1887, pl. 16, figs 84-89) to plicosulcate. Such external morphologies are reported from the rhynchonellides and the terebratulides, but the internal features of de Koninck and Demanet's species remain largely unknown even if some abraded specimens or partial internal moulds of the former display short, divergent dental plates. Due to the absence of data related to the internal features, Terebratula reflexa was doubtfully assigned by Stehli (1961) to his new cryptonellid genus Gacina although he likewise recognized that it could equally belong to Cryptacanthia White \& St. John, 1867. The outline of T. reflexa is less developed in length than those of the other species assigned to Gacina by Stelhi (1961) and is more in accordance with the shape of 


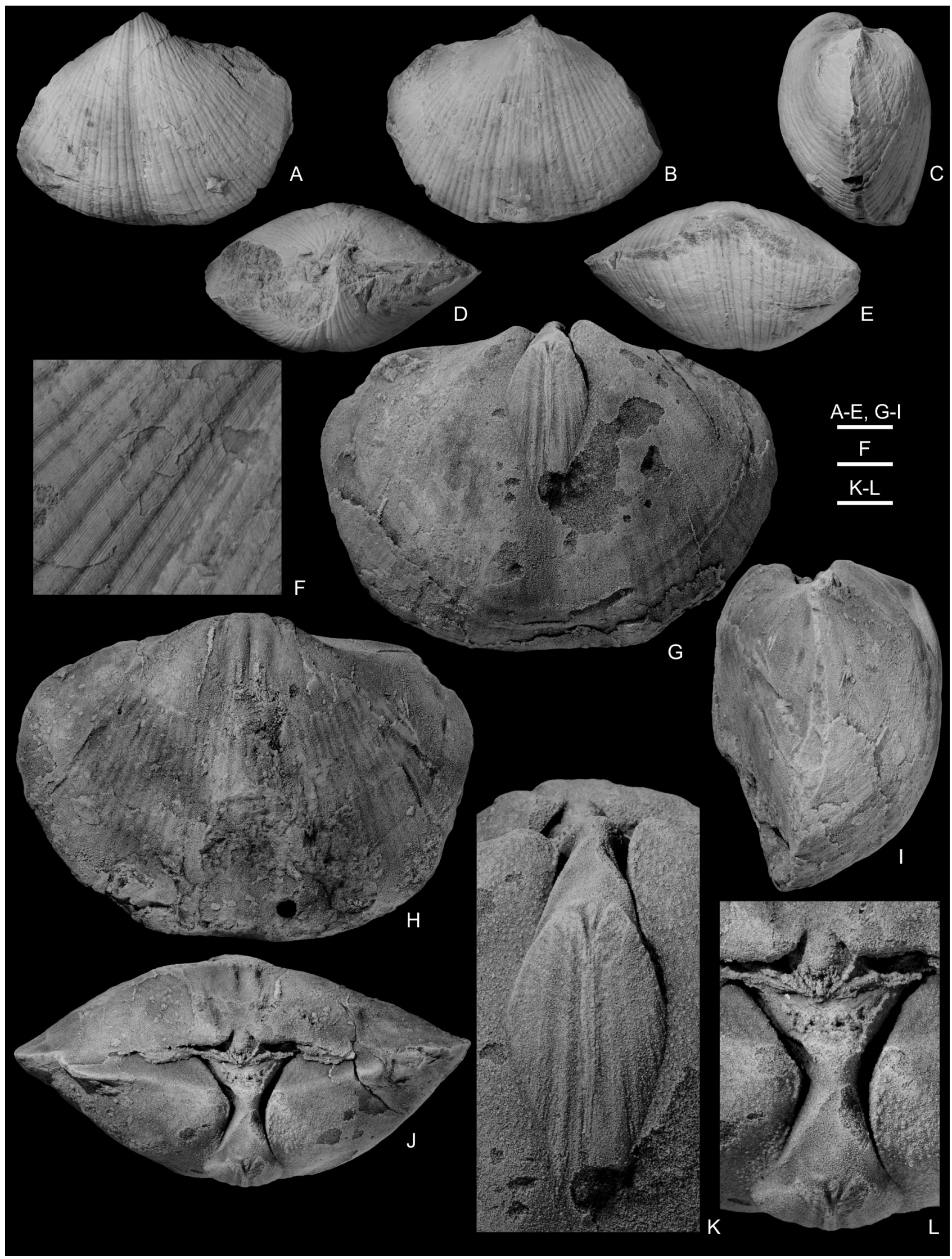

Figure 18. A-F. Spirifer konincki var. attenuiformis Demanet, 1923 [Mesochorispira konincki (Dewalque, 1895)], RBINS a11800 (lectotype), articulated specimen in ventral, dorsal, lateral, posterior and anterior views, and close-up of the microornament in the sulcus; Maredsous, Waulsort Formation (Tournaisian, Ivorian). G-L. Mesochorispira konincki (Dewalque, 1895), UMONS-GFA 2019-11-21/1, slightly crushed internal mould in ventral, dorsal, lateral and posterior views, close-up of the ventral muscle field and detail of the cardinalia and dental plates; Soignies (?), Ecaussinnes Formation (Tournaisian, Ivorian). Scale bars: $10 \mathrm{~mm}$ (A-F, G-L), $2 \mathrm{~mm}$ (F), K-L (5 mm). 


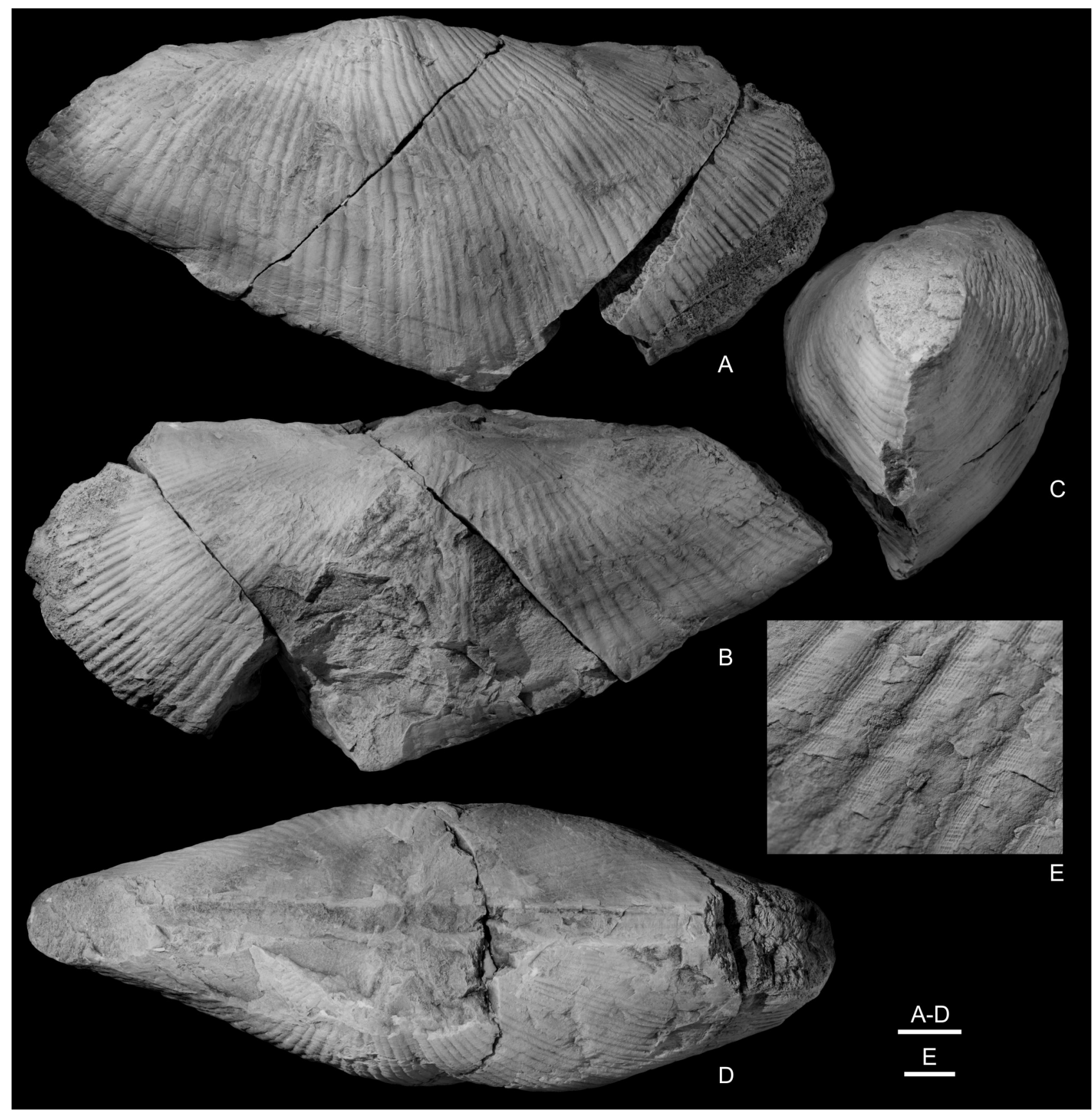

Figure 19. Spirifer konincki var. latissimus Demanet, 1923 [Grandispirifer? latissimus (Demanet, 1923)]; Maredsous, Waulsort Formation (Tournaisian, Ivorian). A-E. RBINS a11801 (lectotype), incomplete and distorted articulated specimen in ventral, dorsal, lateral and posterior views, and enlargement of the microornament on the left ventral flank. Scale bars: $10 \mathrm{~mm}(\mathrm{~A}-\mathrm{D}), 2 \mathrm{~mm}(\mathrm{E})$.

Cryptacanthia species (e.g., White \& St. John, 1867; Dunbar \& Condra, 1932; Cooper, 1957), but the European species can display a strong median dorsal rib (plicosulcate commissure). For all these reasons, both species described in Belgium are doubtfully ascribed to the terebratulide genus Cryptacanthia rather than to Gacina. However, it is not at all excluded that each of them belongs to distinct genera or even distinct order. Further research is therefore required. 1923).

Current name. Cryptacanthia? pentangulata (Demanet,

\subsection{Middle and Upper Devonian trilobites}

Phacops (Phacops) accipitrinus maretiolensis Richter \& Richter, 1933

(Fig. 21A-O)
1933 Phacops (Phacops) accipitrinus maretiolensis Richter \& Richter: 1933, p. 12-15, pl. 2, figs 9-14.

Type material. The illustrated type specimens were selected by Richter \& Richter (1933, pl. 2, figs 9-14) and are photographically illustrated herein for the first time: holotype (RBINS a7812, pl. 2, fig. 9 a-b; Fig. 21A-D) and illustrated paratypes RBINS a7813 (pl. 2, fig. 10; Fig. 21E-H), a7814 (pl. 2, fig. 11; only a plaster mould is available), a7815 (pl. 2, fig. 12; Fig. 21I-J), a7816 (pl. 2, fig. 13; Fig. 21K), a7817 (pl. 2, fig. 14; Fig. 21L-O). The CGF collection also includes one unfigured paratype (CGF 2020.11.10/12, unillustrated).

Type locality and horizon. Maredsous (Bioul 525) (Fig. 1), Etrœungt Formation (latest Famennian, 'Strunian').

Description. See Richter \& Richter (1933).

Remarks. Struve (1976) erected the genus Omegops for 


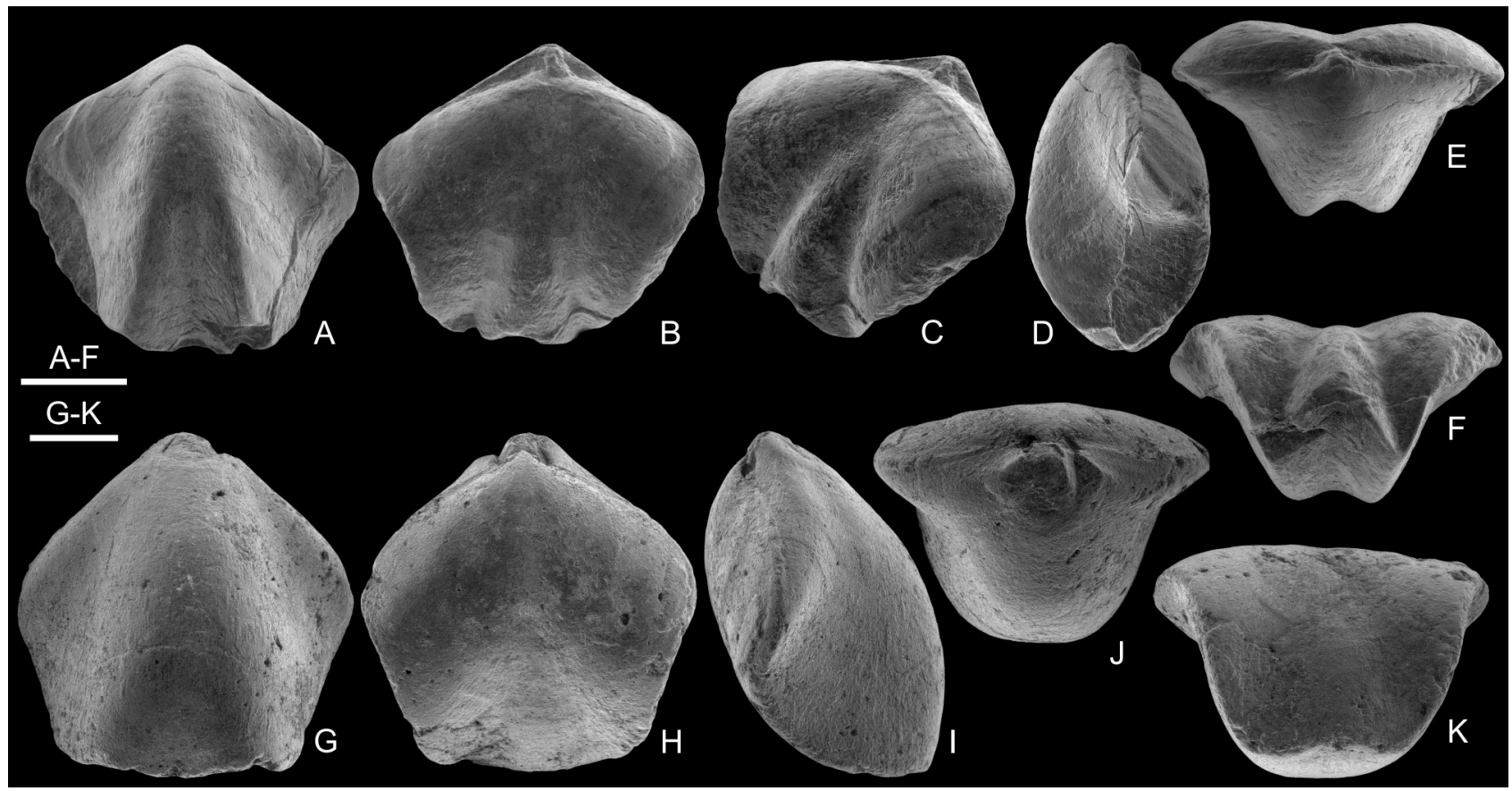

Figure 20. A-F. Camarophoria pentangulata Demanet, 1923 [Cryptacanthia? pentangulata (Demanet, 1923)], RBINS a11828 (lectotype), articulated specimen in ventral, dorsal, oblique dorsal, lateral, posterior and anterior views (SEM); Sosoye, Waulsort Formation or Longpré Formation (Avins Member) (Tournaisian, Ivorian). G-K. Cryptacanthia? reflexa (de Koninck, 1843 in 1842-1844), RBINS a5402 (topotype), internal mould in ventral, dorsal, lateral, posterior and anterior views (SEM); Visé, Visé Formation (Viséan, Warnantian). Scale bars: 10 mm (A-F, G-K).

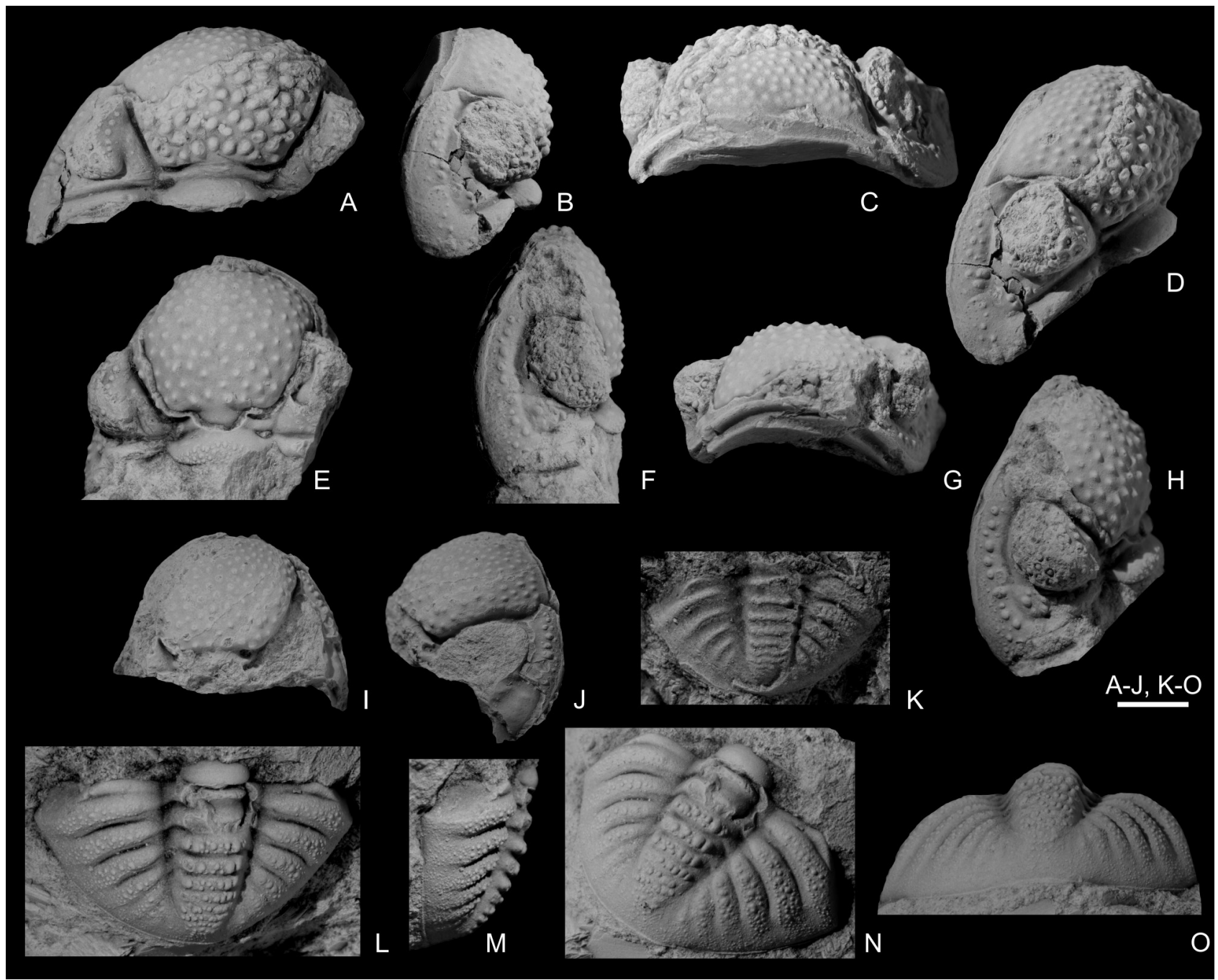

Figure 21. Phacops (Phacops) accipitrinus maretiolensis Richter \& Richter, 1933 [Omegops maretiolensis (Richter \& Richter, 1933)]; Bioul 525, Etrœungt Formation (latest Famennian, Strunian). A-D. RBINS a7812 (holotype), incomplete cephalon in dorsal, lateral, frontal and posterolateral views. E-H. RBINS a7813 (paratype), incomplete cephalon in dorsal, lateral, frontal and posterolateral views. I-J. RBINS A7815 (paratype), incomplete cephalon in dorsal and posterolateral views. K. RBINS a7816 (paratype), pygidium in dorsal view. L-O. RBINS a7817 (paratype), pygidium in dorsal, lateral, posterolateral and frontal views. Scale bar: $4 \mathrm{~mm}(\mathrm{~A}-\mathrm{J}), 2 \mathrm{~mm}(\mathrm{~K}-\mathrm{O})$. 
Calymene accipitrina Phillips, 1841 from the Famennian Pilton Beds of England and Richter \& Richter's subspecies was promoted to a specific status by Crônier \& Feist (in Denayer et al., 2020). 1933)

Current name. Omegops maretiolensis (Richter \& Richter,

\section{Dechenella striata Stainier, 1887}

(Fig. 22A-Y)

1887 Dechenella striata Stainier, p. 80-83, pl. 4, fig. 1a-d.

Type material. The syntypes consist of eight cephalon fragments (RBINS a7629A-H, only the first five are illustrated in Fig. 22A-L, they all participated to Stainier's (1887, pl. 4, fig. 1a) reconstruction figure), four pygidia (RBINS a7630A (Stainier, 1887, pl. 4, fig. 1b, d; Fig. 22Q-S), a7630C (Fig. 22MN), a7630D (Fig. 22O-P), and a7631 (Fig. 22T-V)), and one hypostome (RBINS a7630B (Stainier, 1887, pl. 4, fig. 1c; Fig. $22 \mathrm{~W}-\mathrm{Y}))$

Type locality and horizon. Sombreffe 6189 (Fig. 1), Alvaux Member of the Bois de Bordeaux Formation (Givetian).

Description. See Stainier (1887).

Remarks. Dechenella striata, originally illustrated by strongly embellished drawings and reconstruction, was doubtfully placed in synonymy with $D$. verneuili (Barrande, 1852), namely the type species of the genus Dechenella Kayser, 1880 , by Richter (1912). This opinion was maintained by Richter \& Richter (1950) according to their synonymy list related to Barrande's species and followed notably by Maillieux (1933), Asselberghs (1936), and Fourmarier (1954) in their faunal lists for the Alvaux Formation, although Maillieux (1940b) used Stainier's species name. Note that Stainier's species was erroneously cited as Dechenella striatella by Dormal (1888) (see Forir, 1896). Nevertheless, the type material of Stainier's (1887) has never been photographically illustrated so far. In order to promote the revision of this species, the type material (at least the best preserved) is illustrated photographically for the first time, but no lectotype is designated among the syntypes at this stage.

Current name. Dechenella striata Stainier, 1887.

\section{Acknowledgements}

Special thanks are due to Julien Cillis (RBINS) for the SEM photographic work. The following persons are acknowledged for giving access to the collections under their care and for the loan of material: Bernard Lorent (Abbot of Maredsous), JeanClaude Genard (CGF), Julien Denayer and Valentin Fischer (Université de Liège), Jean-Marc Baele and Nicolas Dupont (Université de Mons), and Nigel T. Monaghan and Matthew A. Parkes (National Museum of Ireland, Dublin). I acknowledge Marie Legrand-Blain (Bordeaux) and Jan Sklenář (National Museum, Prague) for providing literature. Valentin Fisher and Pascal Godefroit (RBINS) are thanked for identification of the Mesozoic vertebrates illustrated in this paper. Thanks also to Edouard Poty (Université de Liège) for his advices on Carboniferous stratigraphy and to Alexander Ivanov (St. Petersburg University) for information related to the euchondrocephalian tooth plates. The manuscript benefited from the thorough reviews of Martin Basse (Senckenberg Forschungsinstitut und Naturmuseum, Frankfurt), Gabriela Adriana Cisterna (Universidad Nacional de La Rioja), Edouard Poty, Yuan-lin Sun (Peking University), and Jacqueline Vander Auwera (Université de Liège).

\section{References}

Amler, M.R.W. \& Herbig, H.-G., 2006. Ostrand der KohlenkalkPlattform und Übergang in das Kulm-Becken im westlichsten Deutschland zwischen Aachen und Wuppertal. In Deutsche Stratigraphische Kommission (ed.), Stratigraphie von Deutschland VI. Unterkarbon (Mississippium). Schriftenreihe der Deutschen Geologischen Gesellschaft, 41, 441-477.

Aretz, M. \& Chevalier, E., 2007. After the collapse of stromatoporidcoral reefs - the Famennian and Dinantian reefs of Belgium: much more than Waulsortian mounds. Geological Society, London, Special Publications, 275, 163-188. https://doi.org/10.1144/ gsl.sp.2007.275.01.11

Asselberghs, E., 1936. Le Dévonien du bord nord du bassin de Namur. Mémoires de l'Institut géologique de l'Université de Louvain, 10, 229-327.

Barrande, J., 1852. Systême Silurien du Centre de la Bohême. $1^{\text {ère }}$ partie : Recherches paléontologiques. Vol. 1. Crustacés : Trilobites. Chez l'auteur et éditeur, Prague \& Paris, 935 p.

Barrande, J., 1887. Systême Silurien du Centre de la Bohême. $1^{\text {ère }}$ partie : Recherches paléontologiques. Vol. 7. Classe des Échinodermes. Ordre des Cystidées. Řivnáč, Prague and Gerhard, Leipzig, $233 \mathrm{p}$

Bassett, M.G. \& Bryant, C., 2006. A Tournaisian brachiopod fauna from south-east Wales. Palaeontology, 49, 485-535. https:// doi.org/10.1111/j.1475-4983.2006.00551.x

Bather, F.A., 1913. Caradocian Cystidea from Girvan. Transactions of the Royal Society of Edinburgh, 49, 359-529. https:// doi.org/10.1017/S0080456800003999

Belanger, I., Delaby, S., Delcambre, B., Ghysel, P., Hennebert, M., Laloux, M., Marion, J.-M., Mottequin, B. \& Pingot, J.-L., 2012. Redéfinition des unités structurales du front varisque utilisées dans le cadre de la nouvelle Carte géologique de Wallonie (Belgique). Geologica Belgica, 15, 169-175.

Béthune, P. de, 1954. Carte géologique de Belgique (échelle 1/500.000). Atlas de Belgique, planche 8. Académie royale de Belgique, Bruxelles.

Bisat, W.S., 1924. The Carboniferous goniatites of the north of England and their zones. Proceedings of the Yorkshire Geological Society, 20, 40-124. https://doi.org/10.1144/pygs.20.1.40

Bisat, W.S., 1952. The goniatite succession at Cowdale Clough, Barnoldswick, Yorkshire. Transactions of the Leeds Geological Association, 6, 155-181.

Bond, G., 1941. Species and variation in British and Belgian Carboniferous Schizophoriidae. Proceedings of the Geologists' Association, 52, 285-303. https://doi.org/10.1016/s0016-7878(41) 80011-X

Booker, F.W., 1929. Preliminary note on new subgenera of Productus and Strophalosia from the Branxton District. Journal and Proceedings of the Royal Society of New South Wales, 63, 24-32.

Bruguière, J.G., 1797. Vers, Coquilles, Mollusques et Polypiers. Tableau encyclopédique et méthodique des trois règnes de la nature, vol. 2. Agasse, Paris, pl. 96-314.

Brüning, K., 1923. Beiträge zur Kenntnis des Rheinisch-westfälischen Unterkarbons, insbesondere der Goniatiten und Korallen in der stratigraphischen Stellung und Gliederung. Geologisches Institut der Universität, Marburg, 1-59.

Brunton, C.H.C., 1968. Silicified brachiopods from the Viséan of County Fermanagh (II). Bulletin of the British Museum (Natural History), Geology, 16, 1-70.

Brunton, C.H.C., 1979. The Lower Carboniferous brachiopod genus Levitusia Muir-Wood, H. M. and Cooper, G. A., from western Europe and the USSR. Bulletin de l'Institut royal des Sciences naturelles de Belgique, Sciences de la Terre, 51/10, 1-23.

Bublichenko, N.L., 1976. Brakhiopody nizhnego karbona Rudnogo Altaya (svity bukhtarminskaya, ul'binskaya, pravoloktevskaya) [Brachiopods of the Lower Carboniferous in Rudny Altai (the 


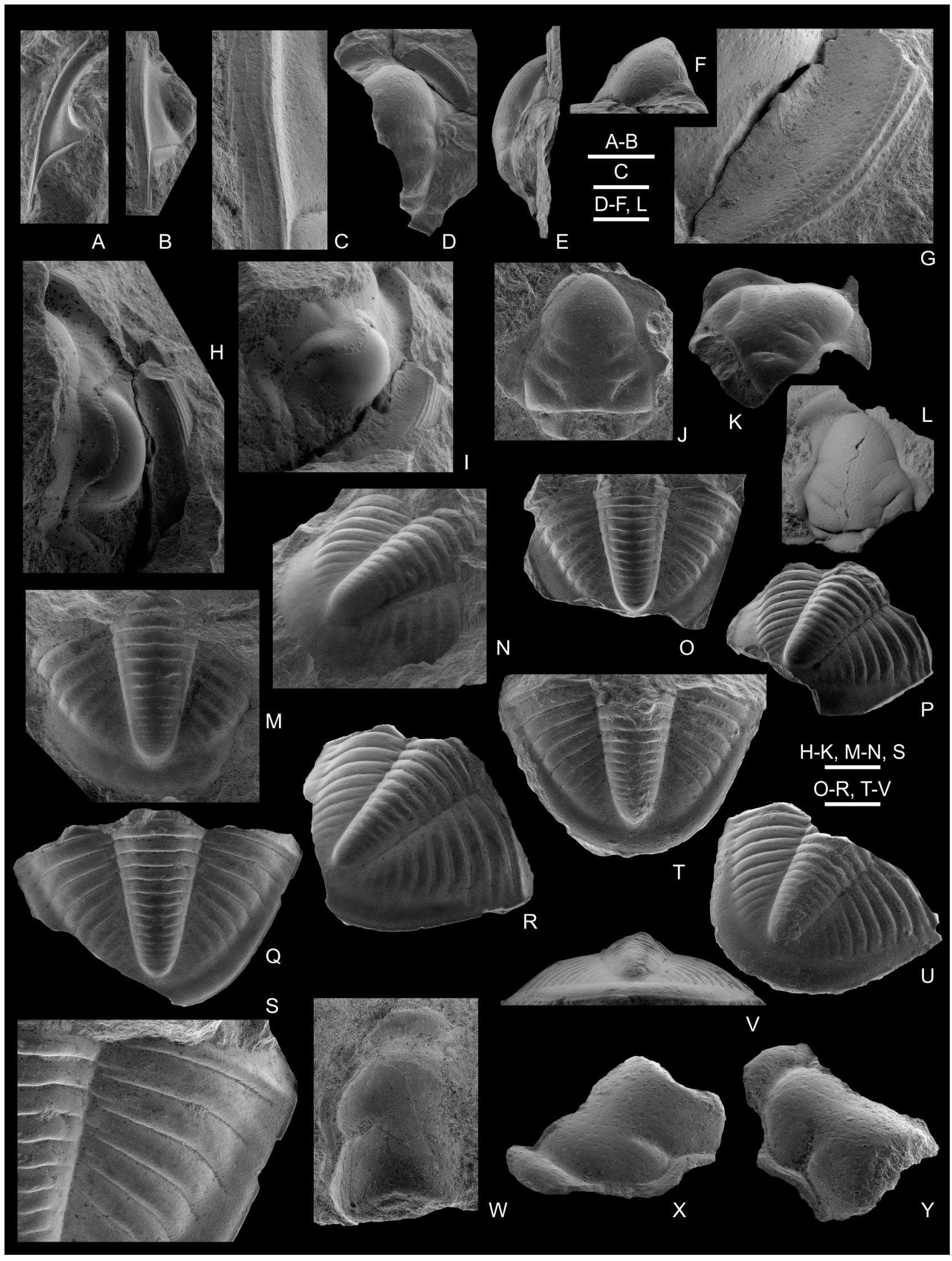

Figure 22. Syntypes of Dechenella striata Stainier, 1887 from Sombreffe 6189, Bois de Bordeaux Formation, Alvaux Member (Givetian). A-C. RBINS a7629A, librigena in dorsal and lateral views, and close-up. D-G. RBINS a7629B, incomplete cranidium in dorsal, lateral and frontal views, and close-up. H-I. RBINS a7629C, incomplete cranidium and librigena in dorsal and oblique lateral views. J-K. RBINS a7629D, incomplete cranidium in dorsal and oblique lateral views. L. RBINS a7629E, almost complete cranidium in dorsal view. M-N. RBINS a7630C, pygidium in dorsal and posterolateral views. O-P. RBINS a7630D, incomplete pygidium in dorsal and posterolateral views. Q-S. RBINS a7630A, incomplete pygidium in dorsal and posterolateral views, and detail. T-V. RBINS a7631, pygidium in dorsal, posterolateral and frontal views. W-Y. RBINS a7630B, hypostome in dorsal, anterolateral and posterolateral views. Specimen RBINS a7629E on Fig. 22L was coated with ammonium chloride; the rest of the material was imaged using a SEM (specimens uncoated). Scale bars: $2 \mathrm{~mm}$ (A-B, D-F, L, O-R, T-V), $0.5 \mathrm{~mm}$ (C), $1 \mathrm{~mm}$ (G, H-K, M-N, S, W-Y). 
Bukhtarminskaya, Ul'binskaya, and Pravoloktevskaya suites)]. Institut Geologicheskikh Nauk im. K. I. Saptaeva. Akademiia Nauk Kazakhskoi. 'Nauka', Alma Ata, 211 p. [In Russian].

Bultynck, P. \& Dejonghe, L., 2002. Devonian lithostratigraphic units (Belgium). Geologica Belgica, 4, 39-69. https://doi.org/10.20341/ gb. 2014.043

Buttgenbach, H., 1898a. Les minéraux du marbre noir de Denée. Annales de la Société géologique de Belgique, 25, Mémoires, 83-89.

Buttgenbach, H., 1898b. La calcite de Villers-en-Fagne. Annales de la Société géologique de Belgique, 25, Mémoires, 91-109.

Buttgenbach, H., 1900. Description des minéraux de fluorine belge. Annales de la Société géologique de Belgique, 27, Mémoires, 111121.

Buttgenbach, H., 1906a. Notes minéralogiques. Annales de la Société géologique de Belgique, 33, M9-M16.

Buttgenbach, H., 1906b. Note sur des cristaux de smithsonite. Bulletin de la Société française de Minéralogie, 29, 190-192. https:// doi.org/10.3406/bulmi.1906.2779

Buttgenbach, H., 1920. Contribution à l'étude des calcites belges. Académie royale de Belgique, Classe des Sciences, Mémoire in- $8^{\circ}$, $2^{\text {ème }}$ série, 4, 1-50.

Buttgenbach, H., 1923. Cristaux de calcite de Bioul. Annales de la Société géologique de Belgique, 46, B170-B172.

Buttgenbach, H., 1925. Calcite et barytine de Bioul. Annales de la Société géologique de Belgique, 48, B63-B68.

Carter, J.L., 1987. Lower Carboniferous brachiopods from the Banff Formation of western Alberta. Geological Survey of Canada, Bulletin, 378, 1-183. https://doi.org/10.4095/122462

Carter, J.L., 1999. Tournaisian (early Osagean) brachiopods from a bioherm in the St. Joe Formation near Kenwood, Oklahoma. Annals of Carnegie Museum, 68, 91-149.

Carter, J.L., 2006. Spiriferoidea. In Kaesler, R.L. (ed.), Treatise on Invertebrate Paleontology, Part H, Brachiopoda, 5 (revised). Geological Society of America and University of Kansas, Boulder and Lawrence, 1769-1811.

Clarke, M.J., 1969. Tasmanian Strophalosiidae. Geological Survey of Tasmania, Records 10, 1-51.

Conil, R., 1968. Le calcaire carbonifère depuis le Tn1a jusqu'au V2a. Annales de la Société géologique de Belgique, 90, B687-B726.

Cooper, G.A. 1957. Loop development of the Pennsylvanian terebratulid Cryptacanthia. Smithsonian Miscellaneous Collections, $134 / 3,1-18$.

Crosse, H., 1863. Mélanges paléontologiques, par le baron P. de Ryckholt, lieutenant-colonel d'artillerie, chevalier de l'ordre de Léopold. - Deuxième et troisième parties. Journal de conchyliologie, 11, 216-219.

Currie, E.D., 1954. Scottish Carboniferous goniatites. Transactions of the Royal Society of Edinburgh, 62, 527-602. https:// doi.org/10.1017/s0080456800009376

Davidson, T., 1860. The Carboniferous system in Scotland characterized by its Brachiopoda. The Geologist, 3, 219-240. https:// doi.org/10.1017/s1359465600021638

Davidson, T., 1861. British fossil Brachiopoda, vol. 2. Carboniferous, part 5, no. 4. Palaeontographical Society, London.

Davis, J.W., 1883. On the fossil fishes of the Carboniferous Limestone Series of Great Britain. Scientific Transactions of the Royal Dublin Society, series 2, 1, 327-600.

Davreux, C.J., 1833. Essai sur la constitution géognostique de la province de Liége. Mémoires couronnés de l'Académie royale des Sciences et Belles-Lettres de Bruxelles, 9, 1-297.

Defrance, M.J.L., 1826. Art. Productus. Dictionnaire des Sciences Naturelles, 43, 349-355.

Dehée, R. 1929. Description de la faune d'Etrœungt - Faune de passage du Dévonien au Carbonifère. Mémoires de la Société géologique de France, nouvelle série, 5, 1-62.

de Koninck, L.-G., 1842-1844. Description des animaux fossiles qui se trouvent dans le terrain carbonifère de Belgique. H. Dessain, Liége, $650 \mathrm{p}$ de Koninck, L.-G., 1847. Monographie du genre Productus. Mémoires de la Société royale des Sciences de Liége, 4, 73-278.

de Koninck, L.-G., 1877. Recherches sur les fossiles paléozoïques de la Nouvelle-Galles du Sud (Australie). Mémoires de la Société royale des Sciences de Liége, $2^{\text {ème }}$ série, 6, 1-140.

de Koninck, L.-G., 1878. Faune du calcaire carbonifère de la Belgique. Première partie : poissons et genre nautile. Annales du Musée royal d'Histoire naturelle de Belgique, 2, 9-76.

de Koninck, L.-G., 1887. Faune du calcaire carbonifère de la Belgique. Sixième partie : brachiopodes. Annales du Musée royal d'Histoire naturelle de Belgique, 14, 1-154.

Delcambre, B. \& Pingot, J.-L., 2018. Carte géologique de Wallonie : Bioul - Yvoir 53/3-4. 1/25 000. Service public de Wallonie, Direction générale de l'Agriculture, des Ressources Naturelles et de l'Environnement, Namur, avec une notice explicative de 128 p.

Deleers, C. \& Pastiels, A., 1952. Contribution à l'étude biométrique de Lingula mytilloides Sowerby du Westphalien de la Belgique. Publications de l'Association pour l'Etude de la Paléontologie et de la Stratigraphie houillères, 12, 3-67.

Delépine, G., 1928. Les brachiopodes du Marbre noir de Dinant (Viséen inférieur). Mémoires du Musée royal d'Histoire naturelle de Belgique, 37, 1-39.

Delépine, G., 1940. Les goniatites du Dinantien de la Belgique. Mémoires du Musée royal d'Histoire naturelle de Belgique, 91, 1-91.

Delmer, A., Dusar, M. \& Delcambre, B., 2002. Upper Carboniferous lithostratigraphic units (Belgium). Geologica Belgica, 4, 95-103. https://doi.org/10.20341/gb.2014.045

Demanet, F., 1923. Le Waulsortien de Sosoye et ses rapports fauniques avec le Waulsortien d'âge Tournaisien supérieur. Mémoires de l'Institut géologique de l'Université de Louvain, 2, 37-285.

Demanet, F., 1934. Les brachiopodes du Dinantien de la Belgique. Premier volume. Atremata, Neotremata, Protremata (pars). Mémoires du Musée royal d'Histoire naturelle de Belgique, 61, 1-116.

Demanet, F., 1941. Faune et stratigraphie de l'étage Namurien de la Belgique. Mémoires du Musée royal d'Histoire naturelle de Belgique, 97, 1-327.

Demanet, F., 1943. Les horizons marins du Westphalien de la Belgique et leurs faunes. Mémoires du Musée royal d'Histoire naturelle de Belgique, 101, 1-166.

Demanet, F., 1958. Contribution à l'étude du Dinantien de la Belgique. Mémoires de l'Institut royal des Sciences naturelles de Belgique, 141, 1-152.

Demanet, F. \& Van Straelen, V., 1938. Faune houillère de la Belgique. In Renier, A., Stockmans, F., Demanet, F. \& Van Straelen, V., Flore et faune houillères de la Belgique. Introduction à l'étude paléontologique du terrain houiller. Volumes 1-2. Musée royal d'Histoire naturelle de Belgique, Bruxelles, 99-246.

Denayer, J., Prestianni, C., Mottequin, B., Hance, L. \& Poty, E., 2020. The Devonian-Carboniferous boundary in Belgium and surrounding areas. Palaeobiodiversity and Palaeoenvironments. https://doi.org/10.1007/s12549-020-00440-5

Derycke, C., Cloutier, R. \& Candilier, A.-M., 1995. Palaeozoic vertebrates of northern France and Belgium: Part II Chondrichthyes, Acanthodii, Actinopterygii (uppermost Silurian to Carboniferous). Geobios, Mémoire Spécial, 19, 343-350. https:// doi.org/10.1016/s0016-6995(95)80136-7

Dewalque, G., 1875. Réunion extraordinaire à Huy et à Liége du 19 au 22 septembre 1875. Compte-rendu de l'excursion du 19 septembre. Annales de la Société géologique de Belgique, 2, Bulletin, 106-124.

Dewalque, G., 1881. Fragments paléontologiques : sur une algue nouvelle de la craie; une algue nouvelle des psammites du Condroz ; un nouveau crustacé phyllopode ; Leperdita Briarti ; Crania Corneti ; Protaster Decheni. Annales de la Société géologique de Belgique, 8, Mémoires, 43-54.

Dewalque, G., 1895. Sur Spirifer mosquensis auct. Annales de la Société géologique de Belgique, 22, Bulletin, 46-47. 
Dewalque, G., 1905. Catalogue des météorites conservées dans les collections belges. Annales de la Société géologique de Belgique, Mémoires, 32, 15-19.

Dorlodot, H. de, 1895. Le Calcaire Carbonifère de la Belgique et ses relations avec celui du Hainaut français. Annales de la Société géologique du Nord, 23, 201-313.

Dormal, V., 1888. Contribution à l'étude du système dévonien dans le bassin de Namur. Annales de la Société géologique de Belgique, 15, Mémoires, 88-111.

Dorsman, L., 1945. The marine fauna of the Carboniferous in the Netherlands. Mededelingen van de Geologische Stichting, 3/3, 3-101.

Dumont, A., 1832. Mémoire sur la constitution géologique de la province de Liége. Mémoires couronnés de l'Académie royale de Sciences et Belles-Lettres de Bruxelles, 8, 1-374.

Dunbar, C.O. \& Condra, G.E., 1932. Brachiopoda of the Pennsylvanian System in Nebraska. Bulletin of the Nebraska Geological Survey, series 2, 5, 1-377.

Dzik, J., 1997. Emergence and succession of Carboniferous conodont and ammonoid communities in the Polish part of the Variscan sea. Acta Palaeontologica Polonica, 42, 57-170.

Ebbighausen, V., Korn, D. \& Bockwinkel, J., 2010. The ammonoids from the Dalle à Merocanites of Timimoun (Late Tournaisian-Early Viséan; Gourara, Algeria). Fossil Record, 13, 153-202. https:// doi.org/10.5194/fr-13-153-2010

Eichwald, E., 1860. Lethaea Rossica ou Paléontologie de la Russie. Schweizerbart'sche Verlagsbuchhandlung, Stuttgart, 1654 p.

Etheridge, R. Jr., 1878. A catalogue of Australian fossils (including Tasmania and the Island of Timor) stratigraphically and zoologically arranged. Cambridge, Cambridge University Press, 232 p. https://doi.org/10.5962/bhl.title. 28810

Etheridge, R. Jr., 1880. Report on a collection of fossils from the Bowen River coalfield and the limestone of the Fanning River, North Queensland. Proceedings of the Royal Physical Society of Edinburgh, 5, 263-328.

Ferguson, J., 1966. Variation in two species of the Carboniferous brachiopod Pleuropugnoides. Proceedings of the Yorkshire Geological Society, 35/3, 353-374. https://doi.org/10.1144/ pygs.35.3.353

Ferguson, J., 1971. Linoprotonia, a new genus of Lower Carboniferous productoid. Proceedings of the Yorkshire Geological Society, 38/4, 549-564. https://doi.org/10.1144/pygs.38.4.549

Forir, H., 1896. Quelques rectifications et additions aux listes de fossiles des terrains paléozoïques de Belgique. Annales de la Société géologique de Belgique, 23, Bulletin, 34-36.

Fourmarier, P., 1954. Le Mésodévonien. In Fourmarier, P. (Ed.), Prodrome d'une description géologique de la Belgique. Société géologique de Belgique, Liège, 120-141.

Fournier, G., 1892. Note préliminaire sur l'existence de la faune de Waulsort dans les étages Viséen et Tournaisien du calcaire carbonifère. Annales de la Société géologique de Belgique, 19, Bulletin, 77-81.

Fournier, G., 1896a. Note sur une météorite tombée à Lesves. Annales de la Société géologique de Belgique, 23, Bulletin, 88-90.

Fournier, G., 1896b. Liste des fossiles du récif de Sosoye. Annales de la Société géologique de Belgique, 23, Bulletin, 44-46.

Fournier, G., 1897a. Quartz violet à Maredsous. Annales de la Société géologique de Belgique, 24, Bulletin, 28.

Fournier, G., 1897b. Découverte de wavellite à Bioul. Annales de la Société géologique de Belgique, 28, Bulletin, 43-44.

Fournier, G., 1897c. Un nouveau trilobite de l'étage Couvinien. Annales de la Société géologique de Belgique, 24, Bulletin, 52.

Fournier, G., 1899a. Aragonite sur les schistes houillers à Namur. Annales de la Société géologique de Belgique, 25, Bulletin, 110.

Fournier, G., 1899b. Calcédoine dans le calcaire carbonifère à Maredret. Annales de la Société géologique de Belgique, 25, Bulletin, 110-111.

Fournier, G., 1899c. Sur des cristaux de quartz dans le calcaire carbonifère. Annales de la Société géologique de Belgique, 25, Bulletin, 111-113.
Fournier, G., 1904. A propos des cristaux de quartz dans le calcaire carbonifère. Annales de la Société géologique de Belgique, 31, B77B80.

Fournier, G. \& Kaisin, F., 1929. Compte-rendu de la session extraordinaire de la Société belge de Géologie, de Paléontologie et d'Hydrologie tenue à Yvoir les 19, 20 et 21 septembre 1927. Bulletin de la Société belge de Géologie, de Paléontologie et d'Hydrologie, 38, 15-45.

Fraipont, Ch., 1908. Notes sur quelques fossiles du Calcaire carbonifère. Annales de la Société géologique de Belgique, 35, M7-M12.

Fraipont, J., 1888a. Une nouvelle Discine du calcaire carbonifère inférieur. Discina (Orbiculö̈dea) multistriata, n. sp. Annales de la Société géologique de Belgique, 15, Bulletin, 162-164.

Fraipont, J., 1888b. Une lingule nouvelle du calcaire carbonifère de Visé (Lingula Konincki). Annales de la Société géologique de Belgique, 15, Bulletin, 142-143.

Fredericks, G., 1933. [Palaeontological notes, 4: On some Upper Palaeozoic brachiopods of Eurasia]. Tsentral'nogo Nauchno Issledovatelskii Geologo Razvedochnii Institut (TSNIGRI), Materialy, 2, 24-33. [In Russian].

Galitskaya, A.I., 1977. Ranne-i Srednekamennougol'nye Produktidy Severnoi Kirgizii [Early and middle Carboniferous Productida of Northern Kirghizia]. Akademiia Nauk Kirgizkoi SSR, Frunze, 298 p. [In Russian].

Gatinaud, G., 1946. Catalogue des Brachiopodes types et figurés de la collection du Laboratoire de Paléontologie du Muséum national d'Histoire naturelle - 1. Productidae et Chonetidae figurés par de Koninck (1843-1846). Bulletin du Muséum national d'Histoire naturelle, $2^{\text {ème }}$ série, $18,372-376$.

Genard, J.-C., 2018. Le Centre Grégoire Fournier. La Lettre de Maredsous, 47/1, 21-30.

Genard, J.-C., 2019. Le Centre Grégoire Fournier ( $2^{\mathrm{e}}$ partie). La Lettre de Maredsous, 48/1, 9-19.

George, T.N., 1932, Brachiopoda from the Cayton Gill Beds. Transactions of the Leeds Geological Association, 5/1, 37-48.

George, T.N. \& Ponsford, D.R.A., 1938. Notes on the morphology of Schizophoria. Transactions of the Leeds Geological Association, 5/4, 227-245.

Ghysens, G. \& Conil, R., 1973. Les Calcschistes de Maredsous et leur localité type (Tournaisien moyen). Bulletin de la Société belge de Géologie, de Paléontologie et d'Hydrologie, 82, 1-16.

Giebel, C.G., 1858. Die Silurische Fauna des Unterharzes nach Herren C. Bischof's Sammlung. Abhandlungen des Naturwissenschaftlichen Vereines der Provinzen Sachsen und Thüringen, 1, 25-70.

Girty, G.H., 1904. New molluscan genera from the Carboniferous. Proceedings of the United States National Museum, 27, 721-736. https://doi.org/10.5479/si.00963801.27-1372.721

Gladtchenko, A.Ya., 1955. Polevoi atlas rukovodiashchikh brakhiopod nizhnego karbona severnoi Kirgizii [Atlas of the Carboniferous brachiopods of Kirgizia]. Izdatel'stvo Instituta Geologii Akademiia Nauk Kirgiz SSR, Frunze, 31 p. [In Russian].

Goldfuss, A., 1839. Beiträge zur Petrefactenkunde. Verhandlungen der Kaiserlichen Leopoldinisch-Carolinischen Akademie der Naturforscher, 11, 327-364.

Gosselet, J., 1888. L'Ardenne. Mémoires pour servir à l'Explication de la Carte géologique détaillée de la France. Baudry \& Cie, Paris, 881 p.

Grady, M.M., 2000. Catalogue of meteorites: with special reference to those represented in the collection of The Natural History Museum, London. Cambridge University Press, Cambridge, 689 p.

Graham, D.K., 1970. Scottish Carboniferous Lingulacea. Bulletin of the Geological Survey of Great Britain, 31, 139-184.

Graham, D.K., 1972. A review of the brachiopod genus Orbiculoidea in the Scottish Carboniferous. Bulletin of the Geological Survey of Great Britain, 38, 43-58.

Grimm, M.C., 1998. Frasnian inarticulate Brachiopoda of the Büdesheim Syncline (Eifel/Germany), of the Saxony Vogtland (Germany) and the Ardennes (Belgium and Northern France). 
Senckenbergiana lethaea, 77, 73-85. https://doi.org/10.1007/ bf03043735

Hall, J., 1847. Palaeontology of New-York, vol. 1. Containing descriptions of the organic remains of the lower division of the NewYork System (equivalent of the Lower Silurian rocks of Europe). C. van Benthuysen, Albany, $338 \mathrm{p}$.

Hall, J., 1858. Report on the Geological Survey of the state of Iowa; embracing the results of investigations made during portions of the years 1855-1857, Palaeontology, vol. 1, part 2. Published by authority of the legislature of Iowa, Des Moines, 473-724.

Hall, J., 1871. Notes on some new or imperfectly known forms among the Brachiopoda, etc. Annual Report of the New York State Cabinet of Natural History, 23, 244-247.

Hance, L., Dejonghe, L., Ghysel, P., Laloux, M. \& Mansy, J.-L., 1999. Influence of heterogeneous lithostructural layering on orogenic deformation in the Variscan Front Zone (eastern Belgium). Tectonophysics, 309,161-177. https://doi.org/10.1016/s0040-1951 (99)00137-7

Hance, L., Poty, E. \& Devuyst, F.-X, 2006a. Tournaisian. Geologica Belgica, 9, 47-53.

Hance, L., Poty, E. \& Devuyst, F.-X., 2006b. Ivorian. Geologica Belgica, 9, 117-122.

Henrard, P., 1951. Le Musée des Sciences naturelles de l'Abbaye de Maredsous. Recueil des travaux présentés aux réunions de la Société des Naturalistes de Namur-Luxembourg, Facultés des Sciences, Namur et Société des Naturalistes Namur-Luxembourg, Namur, 34 p.

Herbig, H.-G., 2016. Mississippian (Early Carboniferous) sequence stratigraphy of the Rhenish Kulm Basin, Germany. Geologica Belgica, 19, 81-110. https://dx.doi.org/10.20341/gb.2016.010

Herbosch, A. \& Verniers, J., 2014. Stratigraphy of the Lower Palaeozoic of the Brabant Massif, Belgium. Part II: The Middle Ordovician to lowest Silurian of the Rebecq Group. Geologica Belgica, 17, 115-136.

Imbrie, J., 1959. Brachiopods of the Traverse Group (Devonian) of Michigan. Part 1. Dalmanellacea, Pentameracea, Strophomenacea, Orthotetacea, Chonetacea and Productacea. Bulletin of the American Museum of Natural History, 116, 349-409.

International Commission on Zoological Nomenclature, 1999. International Code of Zoological Nomenclature, 4th edition. International Trust for Zoological Nomenclature, London, $338 \mathrm{p}$.

Johnston, R.M., 1887. Contribution to the palaeontology of the Upper Palaeozoic rocks of Tasmania. Papers and Proceedings of the Royal Society of Tasmania, 1886, 4-18.

Johnston, R.M., 1888. Systematic account on the geology of Tasmania. William Thomas Strutt (Government Printer), Hobart, 408 p.

Kayser, E., 1880. Dechenella, eine devonische Gruppe der Gattung Phillipsia. Zeitschrift der Deutschen Geologischen Gesellschaft, 32, 703-707.

Keyes, C.R., 1894. Paleontology of Missouri (part 2). Missouri Geological Survey, 5, 1-266.

Kicuła, J. \& Żakowa, H., 1966. Paleozoik okolic Skalbmierza. Kwartalnik Geologiczny, 10, 263-281. [In Polish].

Korejwo, K., 1979. Biostratigraphy of the Carboniferous sediments from the Wierzchowo area (Western Pomerania). Acta Geologica Polonica, 29, 457-473.

Korejwo, K. \& Teller, L., 1968. Stratygrafia karbonu zachodniej części niecki lubelskiej. Acta Geologica Polonica, 18, 153-177. [In Polish].

Korn, D. \& Ebbighausen, V., 2008. The Early Carboniferous (Mississippian) ammonoids from the Chebket el Hamra (Jerada Basin, Morocco). Fossil Record, 11, 83-156. https:// doi.org/10.1002/mmng.200800004

Kucheva, N.A., 2019. Rasprostranenie brahiopod v otlozhenijah nizhnej chasti vizejskogo jarusa Vostochno-Ural'skogo subregiona [Distribution of brachiopods in the Lower Viséan deposits in the Eastern Urals]. Litosfera, 19, 59-80. [In Russian]. https:// doi.org/10.24930/1681-9004-2019-19-1-59-80
Lazarev, S.S., 1976. Morfologiia i Razvitie Brakhiopod (Nadsemeistvo Enteletatsea) [Morphology and evolution of brachiopods (of the superfamily Enteletacea)]. Akademiia Nauk SSSR Paleontologicheskii Institut, Trudy 154, 1-167. [In Russian].

Legrand-Blain, M., 1986. Spiriferacea (Brachiopoda) viséens et serpukhoviens du Sahara algérien. Biostratigraphie du Paléozoïque, 5, 1-85.

Legrand-Blain, M., 2009. Brachiopodes Productidina du Bashkirien inférieur (Pennsylvanien) du bassin houiller du Nord de la France (collections G. Waterlot et J. Chalard). Annales de la Société géologique du Nord, $2^{\text {ème }}$ série, 16, 55-67.

Leriche, M., 1908. Sur quelques plaques dentaires de Cochliodontidés des Terrains carbonifères de la Belgique. Annales de la Société géologique du Nord, 37, 281-286.

Lethiers, F., 1975. Révision de l'espèce Bairdia (Orthobairdia?) hypsela Rome, 1971 (Ostracoda) du Strunien ardennais. Annales de la Société géologique du Nord, 95, 71-75.

Lumsden, G.I., Tulloch, W., Howells, M.F. \& Davies, A., 1967. The geology of the neighbourhood of Langholm: Explanation of oneinch geological sheet 11. Edinburgh, HMSO, Memoirs of the Geological Survey, $255 \mathrm{p}$.

Maillieux, E., 1932. La faune de l'Assise de Winenne (Emsien) moyen sur les bordures méridionale et orientale du bassin de Dinant. Mémoires du Musée royal d'Histoire naturelle de Belgique, 52, 1-102.

Maillieux, E., 1933. Terrains, roches et fossiles de la Belgique. Deuxième édition revue et corrigée. Patrimoine du Musée royal d'Histoire naturelle de Belgique, Bruxelles, 217 p.

Maillieux, E., 1938. Le Couvinien de l'Ardenne et ses faunes. Mémoires du Musée royal d'Histoire naturelle de Belgique, 83, 1-57.

Maillieux, E., 1940a. Contribution à la connaissance du Frasnien moyen (Assise de Frasnes) de la Belgique. Bulletin du Musée royal d'Histoire naturelle de Belgique, 16/14, 1-44.

Maillieux, E., 1940b. Documents pour servir à l'étude du Givetien de l'Ardenne. Bulletin du Musée royal d'Histoire naturelle de Belgique, 16/7, 1-13.

Maillieux, E., 1941. Répartition des brachiopodes dans le Dévonien de l'Ardenne. Bulletin du Musée royal d'Histoire naturelle de Belgique, 17/30, 1-14.

Malaise, C., 1897. Sur Harpes macrocephalus. Annales de la Société géologique de Belgique, 24, Bulletin, 60.

Marion, J.-M. \& Barchy, L., 1999. Carte géologique de Wallonie : Chimay-Couvin 57/7-8. 1/25 000. Ministère de la Région Wallonne, Direction générale des Ressources Naturelles et de l'Environnement, Namur, avec une notice explicative de 89 p.

Martin, W., 1809. Petrificata Derbiensia; or figures and descriptions of petrefactions collected in Derbyshire. D. Lyon, Wigan, 28 p.

Martínez-Chacón, M.L., 1979. Braquiopodos Carboniferos de la Cordillera Cantabrica (Orthida, Strophomenida y Rhynchonellida). Instituto Geológico y Minero de España, Memorias, 96, 1-291.

Maxwell, W.G.H., 1954. Strophalosia in the Permian of Queensland. Journal of Paleontology, 28, 533-559.

May, A., 1984. Über einen Fossilfundort in den Mühlenberg-Schichten (Mittel-Devon) bei Altena (Sauerland) und mitteldevonische Productellinae (Brachiopoda). Dormunder Beiträge zur Landeskunde, 18, 81-94.

May, A., 2003. Die Fossilführung des Mitteldevons im Raum AttendornOlpe (West-Sauerland; Rechtsrheinisches Schiefergebirge). Geologie und Paläontologie in Westfalen, 60, 47-79.

M'Coy, F., 1844. A synopsis of the characters of the Carboniferous Limestone fossils of Ireland. University Press, Dublin, 207 p. https://doi.org/10.5962/bhl.title.11559

Mitchell, W.I. \& Mitchell, M., 1982. The Lower Carboniferous (Upper Viséan) succession at Benburb, Northern Ireland. Institute of Geological Studies, Report 82/12, 1-10.

Morris, J. \& Roberts, G.E., 1862. On the Carboniferous limestone of Oreton and Farlow, Clee Hills, Shropshire. London Geological 
Society Quarterly Journal, 18, 94-102. https://doi.org/10.1144/ gsl.jgs.1862.018.01-02.19

Mortelmans, G., 1969. L'étage Tournaisien dans sa localité-type. Compte-Rendu du $6{ }^{\text {ème }}$ Congrès International de Stratigraphie et de Géologie du Carbonifère, Sheffield 1967, 1, 19-44.

Mortelmans, G., 1973. Evolution paléoécologique et sédimentologique $\mathrm{du}$ Calcaire de Tournai : quelques lignes directrices. Bulletin de la Société belge de Géologie, de Paléontologie et d'Hydrologie, 82, 141-180.

Mottequin, B., 2008a. The 'black marble' of Denée, a fossil conservation deposit from the Lower Carboniferous (Viséan) of southern Belgium. Geological Journal, 43, 197-208. https:// doi.org/10.1002/gj.1102

Mottequin, B., 2008b. New observations on Upper Devonian brachiopods from the Namur-Dinant Basin (Belgium). Geodiversitas, 30, 455-537.

Mottequin, B., 2010. Mississippian (Tournaisian) brachiopods from the Hook Head Formation, County Wexford (south-east Ireland). Special Papers in Palaeontology, 84, 243-285.

Mottequin, B., 2019. An annotated catalogue of types of SilurianDevonian brachiopod species from southern Belgium and northern France in the Royal Belgian Institute of Natural Sciences (18701945), with notes on those curated in other Belgian and foreign institutions. Geologica Belgica, 22, 47-89. https://doi.org/10.20341/ gb.2019.005

Mottequin, B. \& Brice, D., 2016. Upper and uppermost Famennian (Devonian) brachiopods from north-western France (Avesnois) and southern Belgium. Geologica Belgica, 19, 121-134. https:// doi.org/10.20341/gb.2016.004

Mottequin, B. \& Poty, E., 2016. Kellwasser horizons, sea-level changes and brachiopod-coral crises during the late Frasnian in the NamurDinant Basin (southern Belgium): a synopsis. Geological Society, London, Special Publications, 423, 235-250. https:// doi.org/10.1144/sp423.6

Mottequin, B. \& Poty, E., in press. Brachiopods from the historical type area of the Viséan Stage (Carboniferous, Mississippian; Belgium) and the Visé fauna: preliminary remarks. Palaeobiodiversity and Palaeoenvironments.

Mottequin, B. \& Sevastopulo, G., 2009. Predatory boreholes in Tournaisian (Lower Carboniferous) spiriferid brachiopods. Lethaia, 42, 274-282. https://doi.org/10.1111/j.1502-3931.2008.00137.x

Mottequin, B. \& Simon, E., 2017a. Revision of some spiriferide and spiriferinide brachiopods from the historical type area of the Tournaisian stage (Carboniferous, southern Belgium). Paläontologische Zeitschrift, 91, 473-496. https://doi.org/10.1007/ s12542-017-0359-3

Mottequin, B. \& Simon, E., 2017b. New insights on Tournaisian-Visean (Carboniferous, Mississippian) athyridide, orthotetide, rhynchonellide, and strophomenide brachiopods from southern Belgium. Palaeontologia Electronica, 20.2.28A/2, 1-45. https:// doi.org/10.26879/758

Mottequin, B. \& Weyer, D., 2019. On some Mississippian (Carboniferous) brachiopods from neptunian dykes of the Harz Mountains (central Germany). Palaeobiodiversity and Palaeoenvironments, 99(3), 447-475. https://doi.org/10.1007/ s12549-018-0360-1

Mottequin, B., Poty, E. \& Prestianni, C., 2015. Catalogue of the types and illustrated specimens recovered from the 'black marble' of Denée, a marine conservation-Lagerstätte from the Mississippian of southern Belgium. Geologica Belgica, 18, 1-14.

Mottequin, B., Bartzsch, K., Simon, E. \& Weyer, D., 2019. Brachiopod faunas from the basinal facies of southeastern Thuringia (Germany) before and after the Hangenberg Crisis (Devonian-Carboniferous boundary). Palaeontologia Electronica, 22.1.16A, 1-53. https:// doi.org/10.26879/833

Mourlon, M., 1876. Sur l'étage dévonien des psammites du Condroz dans la vallée de la Meuse, entre Lustin et Hermeton-sur-Meuse.
Bulletin de l'Académie royale des Sciences, des Lettres et des Beaux-Arts de Belgique, $2^{\text {ème }}$ série, 42, 845-884.

Mourlon, M., 1881. Géologie de la Belgique, vol. 2. F. Hayez, Bruxelles ; Savy, Paris ; R. Friedländer \& Fils, Berlin, 392 p.

Muir-Wood, H.M., 1928. British Carboniferous Producti 2: Productus (s.s.), semireticularis and longispinus groups. Memoirs of the Great Britain Geological Survey (Palaeontology), 3/1, 217 p.

Muir-Wood, H.M., 1930. The classification of the British Carboniferous brachiopod subfamily Productinae. Annals and Magazine of Natural History, series 10, 5/25, 100-108. https:// doi.org/10.1080/00222933008673110

Muir-Wood, H.M. \& Cooper, G.A., 1960. Morphology, classification and life habits of the Productoidea (Brachiopoda). Geological Society of America Memoir, 81, 1-447. https://doi.org/10.1130/ mem81-p1

Mundy, D.J.C., 1994. Microbialite-sponge-bryozoan-coral framestones in Lower Carboniferous (Late Viséan) buildups of Northern England (UK). Canadian Society of Petroleum Geologists, Memoir, $17,713-729$.

Nalivkin, D.V., 1948. Granitsa turneyskogo i vizeyskogo yarusov na urale i metodika yeyo ustanovleniya [The boundary between the Tournaisian and Viséan stages in the Urals and the method by which it was determined]. Materialy Vsesojuznogo NauchnoIssledovatel'skogo Geologicheskogo Instituta, Paleontologija i stratigrafija, 5, 87-102. [In Russian].

Nalivkin, D.V., 1979. Brakhiopody Turneiskogo Iarusa Urala. [Brachiopods from the Tournaisian Stage of the Urals]. Akademiia Nauk SSSR, Otdelenie Geologii Geofiziki i Geokhimii, Nauka, Leningrad, 248 p. [In Russian].

Nalivkin, D.V. \& Fotieva, N.N., 1973. Brakhiopody pogranichnykh otlozhenij turnejskogo i vizejskogo yarusov zapadnogo sklona Urala [Brachiopods of the Tournaisian-Viséan boundary of the western slope of the Urals]. Institut geologii i razrabotki goriuehikh iskopaemykh, Ministerstvo neftianoi promyshlennosti, Akademiia Nauk SSSR, Nauka, Moskva, 118 p. [In Russian].

Norwood, J.G. \& Pratten, H., 1854. Notice of the genus Chonetes, as found in the Western States and Territories with descriptions of eleven new species [issued as a separate by the Journal of the Academy of Natural Sciences of Philadelphia in August 1854]. Journal of the Academy of Natural Sciences of Philadelphia, series $2,3 / 1,23-32$. [The fascicule 1 of the volume 3 was published in May 1855].

Orbigny, A. d', 1847. Considérations zoologiques et géologiques sur les Brachiopodes ou Palliobranches. Comptes Rendus Hebdomadaires des Séances de l'Académie des Sciences, 25, 193-195, 266-269.

Orbigny, A. d', 1849. Prodrome de Paléontologie stratigraphique universelle des animaux mollusques et rayonnés faisant suite au cours élémentaire de paléontologie et de géologie stratigraphiques, vol. 1. Victor Masson, Paris, 394 p.

Pacaud, D., 2015. Catalogue des types de brachiopodes conservés dans les collections de Paléontologie du Muséum national d'Histoire naturelle de Paris. Fossiles (Revue française de Paléontologie), horssérie 5, 82-98.

Paeckelmann, W., 1930. Die Brachiopoden des deutschen Unterkarbons. 1. Teil: Die Orthiden, Strophomeniden und Choneten des Mittleren und Oberen Unterkarbons. Abhandlungen der Preußischen Geologischen Landesanstalt, Neue Folge, 122, 143-326.

Parent, G.H., 1977. Données floristiques (Spermatophytes et Ptéridophytes) tirées des herbiers de l'abbaye de Maredsous (Denée, Belgique). Dumortiera, 7-8, 6-21.

Parent, G.H., 1979. Origine et inventaire des collections herpétologiques du Musée des sciences naturelles de l'Abbaye de Maredsous (Denée, province de Namur, Belgique). Société des Naturalistes Namur-Luxembourg, nouvelles brèves, 3/1, supplément 2, 1-18.

Parkinson, D., 1954. Quantitative studies of brachiopods from the Lower Carboniferous reef limestones of England. 1. Schizophoria resupinata (Martin). Journal of Paleontology, 28, 367-381. 
Paul, C.R.C., 1968. Morphology and function of dichoporite porestructures in cystoids. Palaeontology, 11, 697-730.

Paul, H., 1939. Die Etrœungt-Schichten des Bergischen Landes. Jahrbuch der Preußischen Geologischen Landesanstalt, 59, 647-726.

Phillips, J., 1836. Illustrations of the geology of Yorkshire, Part 2. The mountain limestone district. John Murray, London, $253 \mathrm{p}$.

Phillips, J., 1841. Figures and descriptions of the Palaeozoic fossils of Cornwall, Devon, and west Somerset. Longman \& Co., London, $231 \mathrm{p}$.

Plodowski, G., 1970. Stratigraphie und Spiriferen (Brachiopoda) des Paläozoikums der Dascht-E Nawar/SW (Afghanistan). Palaeontographica, Abteilung A, 134, 1-132.

Pocock, Y.P., 1965. Devonian and Carboniferous schizophoriid brachiopods from Western Europe. Unpublished Ph.D. Thesis, London University, London, United Kingdom, 283 p.

Pocock, Y.P., 1968. Carboniferous schizophoriid brachiopods from Western Europe. Palaeontology, 11, 64-93.

Portlock, J.E., 1843. Report on the Geology of the County of Londonderry and of parts of Tyrone and Fermanagh. A. Milliken, Dublin, $784 \mathrm{p}$.

Poty, E., 2016. The Dinantian (Mississippian) succession of southern Belgium and surrounding areas: stratigraphy improvement and inferred climate reconstruction. Geologica Belgica, 19, 177-200. https://doi.org/10.20341/gb.2016.014

Poty, E., Hance, L., Lees, A. \& Hennebert, M., 2002. Dinantian lithostratigraphic units (Belgium). Geologica Belgica, 4, 69-94. https://doi.org/10.20341/gb.2014.044

Poty, E., Devuyst, F.-X. \& Hance, L., 2006. Late Devonian and Mississippian foraminiferal and rugose coral zonations of Belgium and Northern France, a tool for Eurasian correlations. Geological Magazine, 143, 829-857. https://doi.org/10.1017/ s0016756806002457

Poty, E., Aretz, M., \& Hance, L., 2014. Belgian substages as a basis for an international chronostratigraphic division of the Tournaisian and Viséan. Geological Magazine, 151, 229-243. https:// doi.org/10.1017/s0016756813000587

Quenstedt, F.A., 1868-1871. Petrefaktenkunde Deutschlands: Abtheilung 1, Band 2. Die Brachiopoden. Fues's Verlag (R. Reisland), Leipzig, 748 p.

Ramsbottom, W.H.C., 1952. The fauna of the Cefn Coed marine band in the Coal Measures at Aberbaiden, near Tondu, Glamorgan. Bulletin of the Great Britain Geological Survey, Palaeontology, 4, 8-32.

Raymond, P.E., 1911. The Brachiopoda and Ostracoda of the Chazyan. Annals of the Carnegie Museum, 7, 215-259.

Regnéll, G., 1951. Revision of the Caradocian-Ashgillian cystoid fauna of Belgium with notes on isolated pelmatozoan stem fragments. Mémoires de l'Institut royal des Sciences de Belgique, 120, 1-47.

Řehoř, F. \& Řehořová, M., 1972. Makrofauna uhlonosného karbonu československé části hornoslezské pánve. Nakladatelstvi Profil, Ostrava, 136 p. [In Czech].

Renard, F., 1896. Notice préliminaire sur la météorite de Lesves. Bulletin de l'Académie royale des Sciences, des Lettres et des Beaux-Arts de Belgique, $3^{\text {ème }}$ série, 31, 654-663.

Richter, R., 1912. Beiträge zur Kenntnis devonischer Trilobiten. Erster Beitrag. Die Gattung Dechenella und einige verwandte Formaen. Abhandlungen der Senckenbergischen Naturforschenden Gesellschaft, 31, 239-340. https://doi.org/10.5962/bhl.title.49511

Richter, R. \& Richter, E., 1933. Die letzten Phacopidae. Bulletin du Musée royal d'Histoire naturelle de Belgique, 9/21, 1-19.

Richter, R. \& Richter, E., 1950. Arten der Dechenellinae (Tril.). Senckenbergiana, 31, 161-184.

Riley, N.J., 1996. Mid-Dinantian ammonoids from the Craven Basin, northwest England. Special papers in Palaeontology, 53, 1-87.

Robaszynski, F., Dhondt, A.V. \& Jagt, J.W.M., 2002. Cretaceous lithostratigraphic units (Belgium). Geologica Belgica, 4, 121-134. https://doi.org/10.20341/gb.2014.049
Rome, R., 1971. Contribution à l'étude des Ostracodes du Tournaisien de la Belgique. Mémoires de l'Institut géologique de l'Université de Louvain, 27, 3-46.

Rosenberg, G. \& Petit, R.E., 1987. Ryckholt's Mélanges paléontologiques, 1851-1862, with a new name for Tudicula H. \& A. Adams, non Ryckholt. Proceedings of the Academy of Natural Sciences of Philadelphia, 139, 53-64.

Ryckholt, P. de, 1851. Mélanges paléontologiques, première partie Mémoires couronnés des Savants étrangers de l'Académie royale des Sciences, des Lettres et des Beaux-Arts de Belgique, 24, 1-176.

Ryckholt, P. de, 1854. Mélanges paléontologiques. Deuxième partie Privately printed, $205 \mathrm{p}$

Sartenaer, P. \& Plodowski, G., 2002. Description of Mesochorispira konincki (Dewalque, 1895), a spiriferid brachiopod from the Belgian upper Tournaisian. Bulletin de l'Institut Royal des Sciences naturelles de Belgique, Sciences de la Terre, 72, 69-84.

Sarytcheva, T.G., Sokolskaya, A.N., Beznosova, G.A. \& Maksimova, S.A., 1963. Brakhiopody i paleogeografiia Karbona Kuznetskoi kotloviny [Carboniferous brachiopods and palaeogeography of the Kuznetsk Basin]. Akademiia Nauk SSSR, Paleontologicheskii Institut, Trudy 95, 1-547. [In Russian].

Schindewolf, O.H., 1951. Über ein neues Vorkommen unterkarbonischer Pericyclus-Schichten im Oberharz. Neues Jahrbuch für Geologie und Paläontologie, Abhandlungen, 93, 23-116.

Schmidt, W.E., 1944. Ophiaulax decheni (Dewalque), ein Schlangenstern in den Angertal-Schichten des Blattes Kettwig (Ruhrgebiet). Zeitschrift der Deutschen Geologischen Gesellschaft, 96, 170-175.

Schwarzbach, M. \& Reichelt, H., 1940. Neue marine Horizonte aus dem oberschlesischen Steinkohlenbecken und ihre praktische Bedeutung. Glückauf - Berg- und Hüttenmännische Zeitschrift, 76, 276-281.

Shephard-Thorn, E.R., 1963. The Carboniferous Limestone Succession in North-West County Limerick, Ireland. Proceedings of the Royal Irish Academy, Section B (Biological, Geological, and Chemical Science), 62, 267-294.

Shi, G.R., Chen, Z.-Q., Lee, S. \& Zhan, L.-P., 2016. Early Carboniferous spiriferoid brachiopods from the Qaidam Basin, Northwest China: Taxonomy, biostratigraphy and biogeography. Palaeoworld, 25, 581-599. https://doi.org/10.1016/j.palwor.2016.07.003

Shumard, B.F., 1855. Description of a geological section on the Mississippi River, from St. Louis to Commerce. Annual reports of the Geological Survey of Missouri, 1-2/2, 137-208.

Sohn, I.G., 1960. Paleozoic species of Bairdia and related genera. United States Geological Survey Professional Paper, 330A, 1-105. https://doi.org/10.3133/pp330A

Sowerby, J., 1812-1815. The Mineral Conchology of Great Britain, vol. 1. Published by the author, London, $234 \mathrm{p}$.

Sowerby, J., 1821-1822. The Mineral Conchology of Great Britain, vol. 4. Published by the author, London, $114 \mathrm{p}$.

Spriestersbach, J., 1942. Lenneschiefer (Stratigraphie, Fazies und Fauna) Abhandlungen des Reichsamts für Bodenforschung, 203, 1-219.

Stainier, X., 1887. Note sur un trilobite nouveau et sur les Pentamerus des calcaires d'Humerée. Annales de la Société géologique de Belgique, 14, Mémoires, 75-85.

Stainier, X., 1894. Un Spiraxis nouveau du Dévonien belge. Bulletin de la Société belge de Géologie, de Paléontologie et d'Hydrologie, 8, Mémoires, 23-28.

Stehli, F.G., 1954. Lower Leonardian Brachiopoda of the Sierra Diablo. Bulletin of the American Museum of natural History, 105, 263-358.

Stehli, F.G., 1961. New genera of Upper Paleozoic terebratuloids. Journal of Paleontology, 35, 457-466.

Stoliczka, F., 1870-1871. Cretaceous fauna of southern India. Vol. 3. The Pelecypoda, with a review of all known genera of this class, fossil and Recent. Memoirs of the Geological Survey of India, Palaeontologia Indica, 6, 1-537. 
Struve, W., 1976. Beiträge zur Kenntnis der Phacopina (Trilobita), 9: Phacops (Omegops) n. sg. (Trilobita; Ober-Devon). Senckenbergiana lethaea, 56, 429-451.

Taghon, P., Bonino, E. \& Mottequin, B., 2012. A new representative of the lichid genus Ohleum (Trilobita) from the Eifelian (Middle Devonian) of southern Belgium. Geologica Belgica, 15, 120-125.

Thomas, G.A., 1971. Carboniferous and Early Permian brachiopods from western and northern Australia. Bureau of Mineral Resources, Geology Bulletin, 56, 1-215.

Thomas, I., 1910. The British Carboniferous Orthotetinae. Great Britain Geological Survey Memoir, 1/2, 83-134.

Thomas, I., 1914. The British Carboniferous Producti, part 1: genera Pustula and Overtonia. Memoirs of the Geological Survey of Great Britain (Palaeontology), 1/4, 197-366.

Tornquist, A., 1895. Das fossilführende Untercarbon am östlichen Rossbergmassiv in den Südvogesen. 1. Einleitung, Beschreibung der Brachiopoden-Fauna. Abhandlungen zur geologischen Specialkarte von Elsass-Lothringen, 5/4, 377-528. https:// doi.org/10.3931/e-rara-19574

Ubaghs, G., 1941. Description de quelques ophiures du Famennien de la Belgique. Bulletin du Musée royal d'Histoire naturelle de Belgique, 17/44, 1-31.

Van Beneden, M., 1863. Sur un aérolithe aperçu en Belgique le 7 décembre 1863. Bulletin de l'Académie royale des Sciences, des Lettres et des Beaux-Arts de Belgique, 2e série, 16, 621-623.

Van Leckwyck, W., Scheere, J., Demanet, F. \& Willière, Y., 1951. Etude géologique du Bassin Houiller de Mons - Lithologie, flore et faune du Westphalien C dans la partie occidentale du Massif du Borinage. Publications de l'Association pour l'Etude de la Paléontologie et de la Stratigraphie houillères, 10, 3-58.

Vanmeirhaeghe, J., Storme, A., Van Noten, K., Van Grootel, G. \& Verniers, J., 2005. Chitinozoan biozonation and new lithostratigraphical data in the Upper Ordovician of the Fauquez and Asquempont areas (Brabant Massif, Belgium). Geologica Belgica, 8, 145-159.

Verniers, J., Van Grootel, G. \& Debacker, T.N., 2005. Upper Ordovician lithostratigraphy and structural architecture of the Fauquez area (Brabant Massif, Belgium). Geologica Belgica, 8, 160-175.

Verniers, J., Herbosch, A., Vanguestaine, M., Geukens, F., Delcambre, B., Pingot, J.-L., Belanger, I., Hennebert, M., Debacker, T., Sintubin, M. \& De Vos, W., 2002. Cambrian-Ordovician-Silurian lithostratigraphic units (Belgium). Geologica Belgica, 4, 5-38. https:// doi.org/10.20341/gb.2014.042

Vokes, H.E., 1967. Genera of Bivalvia: a systematic and bibliographic catalogue. Bulletins of American Paleontology, 51, 103-394.

Vokes, H.E., 1980. Genera of the Bivalvia: A systematic and bibliographic catalogue (revised and updated). Paleontological Research Institution, Ithaca, New York, $307 \mathrm{p}$.

White, C.A. \& St. John, O., 1867. Descriptions of new Subcarboniferous Coal-Measure fossils, collected upon the Geological Survey of Iowa; together with a notice of new generic characters involved in two species of Brachiopoda. Transactions of the Chicago Academy of Sciences, 1, 115-127.

Winkler Prins, C.F. \& Amler, M.R.W., 2006. Brachiopoden. In Deutsche Stratigraphische Kommission (Ed.), Stratigraphie von Deutschland VI. Unterkarbon (Mississippium), Schriftenreihe der Deutschen Gesellschaft für Geowissenschaften, 41, 89-100.

Williams, A. \& Curry, G.B., 1991. The microarchitecture of some acrotretide brachiopods. In MacKinnon, D.I., Lee, D.E. \& Campbell, J.D. (eds), Brachiopods Through Time, Proceedings of the 2nd International Brachiopod Congress, University of Otago, Dunedin, New Zealand, 1990. Balkema, Rotterdam, 133-140.

Wright, A.D., 1965. Superfamily Enteletacea Waagen, 1884. In Moore, R.C. (ed.), Treatise on Invertebrate Paleontology, Part H, Brachiopoda, 1. The Geological Society of America and The University of Kansas Press, Lawrence, Kansas, H328-H346.

Yang Shipu, 1959. [A new genus of Viséan spiriferid-Grandispirifer, gen. nov.]. Acta Palaeontologica Sinica, 7/2, 111-120. [In Chinese].
Żakowa, H., 1989. Orthid brachiopods from the Upper Viséan (Carboniferous) of the Świętokrzyskie Mts., Poland. Acta Palaeontologica Polonica, 34, 91-124

Żakowa, H. \& Chlebowski, R., 1984. Nowe dane o karbonie w okolicy Bolechowic i Kowali (Góry Świętokrzyskie). Kwartalnik Geologiczny, 28, 317-340. [In Polish].

Zamora, S., Nardin, E., Esteve, J. \& Gutiérrez-Marco, J.C., 2019. New rhombiferan blastozoans (Echinodermata) from the Late Ordovician of Morocco. Geological Society, London, Special Publications, 485. https://doi.org/10.1144/sp485.10
Manuscript received 27.07.2020, accepted in revised form 12.11.2020, available online 17.03.2021. 